\title{
Life Cycle Assessment of a
}

Natural Gas Combined-Cycle

Power Generation System

Pamela L. Spath

Margaret K. Mann

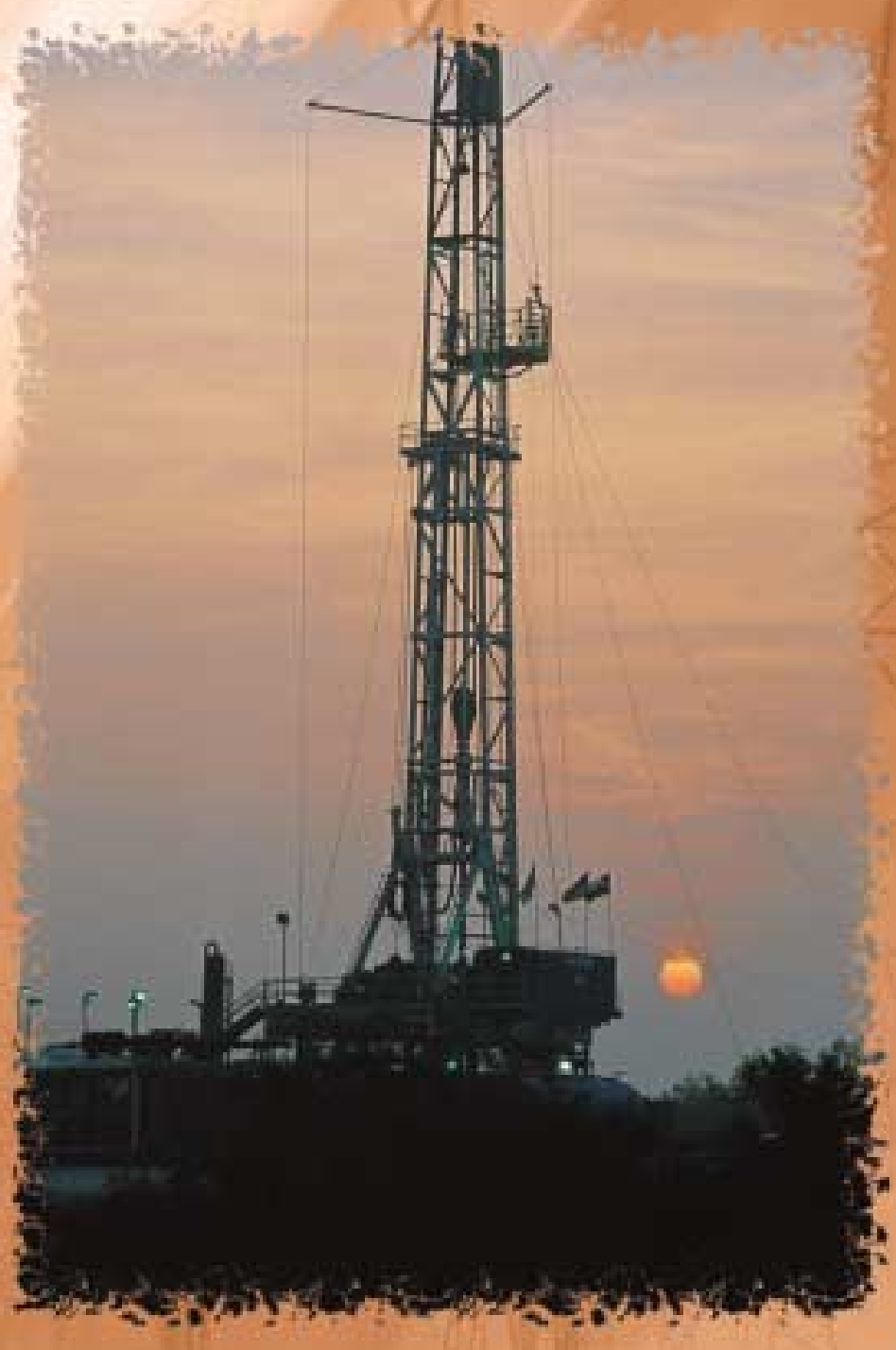

\section{Life Cycle Assessment}




\section{Life Cycle Assessment of a Natural Gas Combined-Cycle Power Generation System}

\section{Pamela L. Spath \\ Margaret K. Mann}

Prepared under Task No. BP00.1030

,




\section{NOTICE}

This report was prepared as an account of work sponsored by an agency of the United States government. Neither the United States government nor any agency thereof, nor any of their employees, makes any warranty, express or implied, or assumes any legal liability or responsibility for the accuracy, completeness, or usefulness of any information, apparatus, product, or process disclosed, or represents that its use would not infringe privately owned rights. Reference herein to any specific commercial product, process, or service by trade name, trademark, manufacturer, or otherwise does not necessarily constitute or imply its endorsement, recommendation, or favoring by the United States government or any agency thereof. The views and opinions of authors expressed herein do not necessarily state or reflect those of the United States government or any agency thereof.

Available electronically at http://www.doe.gov/bridge

Available for a processing fee to U.S. Department of Energy

and its contractors, in paper, from:

U.S. Department of Energy

Office of Scientific and Technical Information

P.O. Box 62

Oak Ridge, TN 37831-0062

phone: 865.576 .8401

fax: 865.576.5728

email: reports@adonis.osti.gov

Available for sale to the public, in paper, from:

U.S. Department of Commerce

National Technical Information Service

5285 Port Royal Road

Springfield, VA 22161

phone: 800.553.6847

fax: 703.605.6900

email: orders@ntis.fedworld.gov

online ordering: http://www.ntis.gov/ordering.htm 


\section{EXECUTIVE SUMMARY}

Natural gas accounts for $22 \%$ of all of the energy consumed in the United States. It is used for steam and heat production in industrial processes, residential and commercial heating, and electric power generation. Currently, $15 \%$ of utility and non-utility power is produced from natural gas, while the U.S. Department of Energy's Energy Information Administration projects that 33\% of the electricity generated in 2020 will be from natural gas-fired power plants (U.S. DOE, December 1998, p.5). Because of its importance in the power mix in the United States, a life cycle assessment (LCA) on electricity generation via a natural gas combined-cycle (NGCC) system has been performed. In the near future, this study will be compared with LCAs for other electricity generation systems previously performed by NREL: biomass gasification combined-cycle, coal-fired power production, biomass cofiring in a coal-fired power plant, and direct-fired biomass power generation (Mann and Spath, 1997; Spath and Mann, 1999; Mann and Spath, 2000; and Spath and Mann, 2000). This will give a picture of the environmental benefits and drawbacks of these various power generation technologies.

Since upstream processes can be significantly polluting, the application of LCA methodologies is important for gaining an understanding of the total environmental impact of a process. The system evaluated in this study was divided into the following process steps: construction and decommissioning of the power plant, construction of the natural gas pipeline, natural gas production and distribution, ammonia production and distribution for $\mathrm{NO}_{\mathrm{x}}$ removal, and power plant operation.

The size of the NGCC power plant is $505 \mathrm{MW}$. The plant configuration consists of two gas turbines, a three pressure heat recovery steam generator, and a condensing reheat steam turbine. To minimize the plant's $\mathrm{NO}_{\mathrm{x}}$ emissions, the power plant incorporates selective catalytic reduction (SCR) with water injection. Additionally, the base case of this LCA assumes that $1.4 \%$ of the gross natural gas that is extracted is lost to the atmosphere as fugitive emissions (Harrison et al, 1997).

This study found that $\mathrm{CO}_{2}$ accounts for $99 \mathrm{wt} \%$ of all air emissions. Methane is emitted in the next highest quantity, $74 \%$ of which are fugitive emissions from natural gas production and distribution. Following $\mathrm{CO}_{2}$ and $\mathrm{CH}_{4}$, the next highest air emissions, in order of decreasing amount, include non-methane hydrocarbons (NMHCs), $\mathrm{NO}_{\mathrm{x}}$, $\mathrm{SO}_{x}, \mathrm{CO}$, particulates, and benzene.

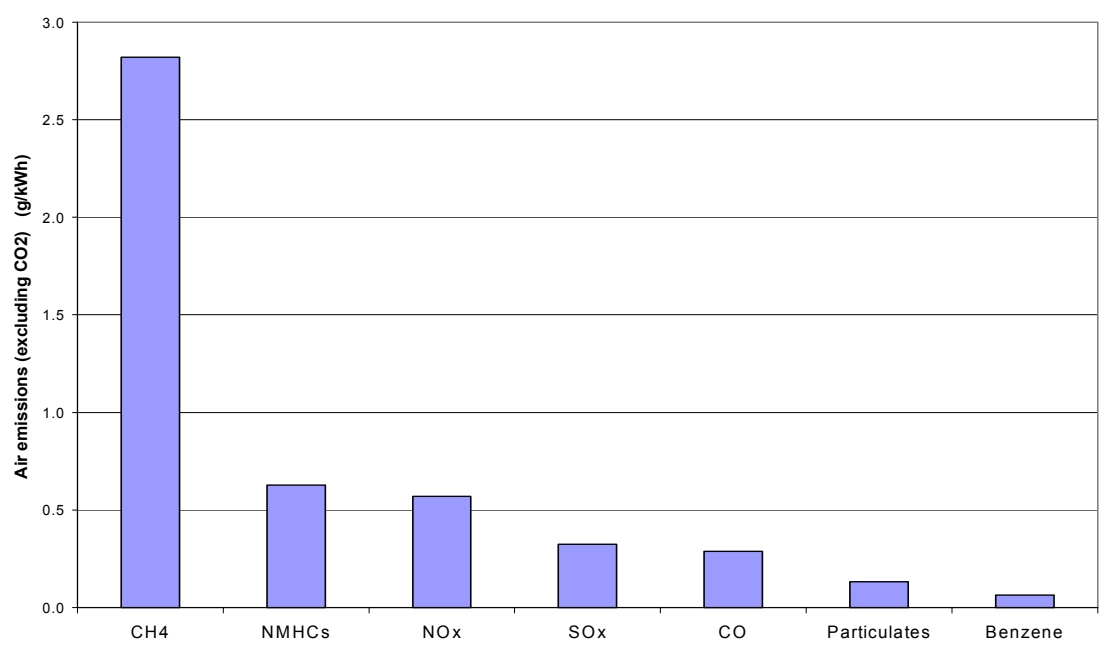

The contributions from three greenhouse gases, $\mathrm{CO}_{2}, \mathrm{CH}_{4}$, and $\mathrm{N}_{2} \mathrm{O}$, are considered in the assessment of the global warming potential (GWP) of the system. According to the Intergovernmental Panel on Climate Change (IPCC) the cumulative capacities of $\mathrm{CH}_{4}$ and $\mathrm{N}_{2} \mathrm{O}$ to contribute to the warming of the atmosphere are 21 and 310 times higher than $\mathrm{CO}_{2}$, respectively, for a 100 year time frame (Houghton, et al, 1996). The GWP for this system is $499.1 \mathrm{~g} \mathrm{CO}_{2}$-equivalent $/ \mathrm{kWh}$. The following table contains the emission rates for the different greenhouse gases and their contribution to the total GWP. 
Emissions of Greenhouse Gases and Contribution to GWP

\begin{tabular}{|l|c|c|c|c|c|}
\hline & $\begin{array}{c}\text { Emission } \\
\text { amount } \\
(\mathrm{g} / \mathrm{kWh})\end{array}$ & $\begin{array}{c}\text { Percent of } \\
\text { greenhouse gases in } \\
\text { this table (\%) }\end{array}$ & $\begin{array}{c}\mathrm{GWP} \text { relative to } \mathrm{CO}_{2} \\
(100 \text { year IPCC values })\end{array}$ & $\begin{array}{c}\text { GWP value } \\
\left(\mathrm{g} \mathrm{CO}_{2} \text {-equivalent } / \mathrm{kWh}\right)\end{array}$ & $\begin{array}{c}\text { Percent } \\
\text { contribution } \\
\text { to GWP (\%) }\end{array}$ \\
\hline $\mathrm{CO}_{2}$ & 439.7 & 99.4 & 1 & 439.7 & 88.1 \\
\hline $\mathrm{CH}_{4}$ & 2.8 & 0.6 & 21 & 59.2 & 11.9 \\
\hline $\mathrm{N}_{2} \mathrm{O}$ & 0.00073 & 0.0002 & 310 & 0.2 & 0.04 \\
\hline
\end{tabular}

The GWP of the system can also be divided among the different system operations. The table below shows the contribution of each subsystem to the overall GWP of the system. The power plant $\mathrm{CO}_{2}$ emissions contribute the most to the GWP at $64 \%$. Because of the natural gas lost to the atmosphere, the natural gas production and distribution subsystem is responsible for nearly all of the remainder of the system's GWP.

GWP Contribution For Each System Component

\begin{tabular}{|l|c|c|}
\hline \multicolumn{1}{|c|}{ Process step } & $\begin{array}{c}\text { GWP value } \\
\left(\mathrm{g} \mathrm{CO}_{2} \text {-equivalent } / \mathrm{kWh}\right)\end{array}$ & $\begin{array}{c}\text { Percent contribution } \\
\text { to GWP (\%) }\end{array}$ \\
\hline Power plant operation & 372.2 & 74.6 \\
\hline Natural gas production \& distribution & 124.5 & 24.9 \\
\hline Construction \& decommissioning & 2.0 & 0.4 \\
\hline Ammonia production \& distribution & 0.4 & 0.1 \\
\hline Total & 499.1 & 100.0 \\
\hline
\end{tabular}

Note: The construction and decommissioning subsystem includes power plant construction and decommissioning as well as construction of the natural gas pipeline.

The power plant efficiency for this NGCC system is $48.8 \%$ (higher heating value (HHV) basis). This is defined as the energy to the grid divided by the energy in the natural gas feedstock to the power plant. Four other types of efficiencies/energy ratios were defined to study the energy budget of the system.

\section{Energy Efficiency and Energy Ratio Definitions}

\begin{tabular}{|c|c|c|c|}
\hline Life cycle efficiency (\%) (a) & $\begin{array}{c}\text { External energy } \\
\text { efficiency (\%) (b) }\end{array}$ & Net energy ratio (c) & External energy ratio (d) \\
\hline$=\frac{E g-E u-E n}{E n}$ & $=\frac{E g-E u}{E n}$ & $=\frac{E g}{E f f}$ & $=\frac{E g}{E f f-E n}$ \\
\hline where: & $\begin{array}{l}\text { Eg = electric energy delivered to the utility grid } \\
\text { Eu = energy consumed by all upstream processes required to operate power plant } \\
\text { En = energy contained in the natural gas fed to the power plant } \\
\text { Eff = fossil fuel energy consumed within the system (e) }\end{array}$ \\
\hline
\end{tabular}

(a) Includes the energy consumed by all of the processes.

(b) Excludes the heating value of the natural gas feedstock from the life cycle efficiency formula.

(c) Illustrates how much energy is produced for each unit of fossil fuel energy consumed.

(d) Excludes the energy of the natural gas to the power plant.

(e) Includes the natural gas fed to the power plant since this resource is consumed within the boundaries of the system. 
The net energy ratio is a more accurate measure of the net energy yield from the system than the external energy ratio because it accounts for all of the fossil energy inputs. The following table contains the resulting efficiencies and energy ratios for the NGCC system. All efficiencies are given on a LHV basis.

\section{Efficiencies and Energy Ratio Results (LHV basis)}

\begin{tabular}{|c|c|c|c|c|}
\hline System & $\begin{array}{c}\text { Life cycle } \\
\text { efficiency } \\
(\%)\end{array}$ & $\begin{array}{c}\text { External energy } \\
\text { efficiency } \\
(\%)\end{array}$ & $\begin{array}{c}\text { Net energy } \\
\text { ratio }\end{array}$ & $\begin{array}{c}\text { External } \\
\text { energy ratio }\end{array}$ \\
\hline $\begin{array}{l}\text { Natural gas } \\
\text { combined-cycle }\end{array}$ & $-70.1 \%$ & $29.9 \%$ & 0.4 & 2.2 \\
\hline
\end{tabular}

Because natural gas is not a renewable resource, the life cycle efficiency is negative, indicating that more energy is consumed by the system than is produced in the form of electricity (i.e., if the feedstock were renewable then the life cycle efficiency and external energy efficiency would be the same). Additionally, the net energy ratio in the table above shows that for every MJ of fossil energy consumed $0.4 \mathrm{MJ}$ of electricity are produced. Excluding the consumption of the natural gas feedstock, the external energy efficiency and the external energy ratio indicate that upstream processes are large consumers of energy. Disregarding the energy in the natural gas feedstock, $98 \%$ of the total energy is consumed in the production and distribution of natural gas. This subsystem can be further broken up into natural gas extraction, separation and dehydration, sweetening, and pipeline transport. Of these operations, the natural gas extraction and transport steps consume the most energy. Drilling requires electricity, which is supplied by diesel combustion engines; the pipeline compressors move the natural gas using a combination of grid electricity and natural gas.

In terms of resource consumption, natural gas is used at the highest rate, accounting for nearly $98 \mathrm{wt} \%$ of the total resources. This is followed by coal at $1.0 \mathrm{wt} \%$, iron ore plus scrap at $0.7 \mathrm{wt} \%$, oil at $0.4 \mathrm{wt} \%$, and limestone at $0.4 \mathrm{wt} \%$. Practically all of the iron and limestone are used in the construction of the power plant and pipeline, while the production and distribution of the natural gas consumes the vast majority of the coal and oil. Also, the resource requirements associated with pipeline construction are greater than those due to power plant construction.

The total amount of water pollutants was found to be extremely small $(0.01 \mathrm{~g} / \mathrm{kWh})$ compared to the other emissions. The main water emissions are oils and dissolved matter, making up $80 \mathrm{wt} \%$ of the total water emissions. The oils come primarily from natural gas production and distribution, while the dissolved matter is produced from the material manufacturing steps involved in pipeline and power plant construction.

In terms of solid waste, $94 \mathrm{wt} \%$ percent of the system's total comes from the natural gas production and distribution block. A large percentage of the waste, $65 \%$ of the total, comes from pipeline transport. Although the majority of the pipeline compressors are driven by reciprocating engines and turbines which are fueled by the natural gas, there are some electrical machines and electrical requirements at the compressor stations. Since most of the electricity in the U.S. is generated from coal-fired power plants, the majority of the waste will be in the form of coal ash and flue gas clean-up waste. The second largest waste source is natural gas extraction ( $29 \%$ of the total waste). The only waste stream from the power plant itself will be a small amount of spent catalyst which is generated every one to five years from the SCR unit.

A sensitivity analysis on this system determined that changes in two parameters, power plant efficiency and natural gas losses, have the largest effect on the results. Although NGCC is currently the most efficient technology available for large-scale electricity production, any increases in efficiency will reduce resulting environmental stressors throughout the system. Reducing natural gas losses during production and distribution increases the net energy balance and lowers the GWP. 


\section{Table of Contents}

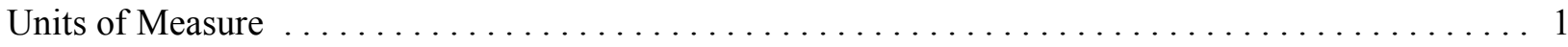

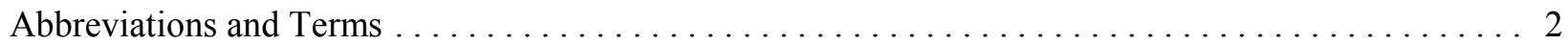

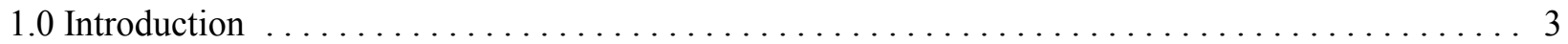

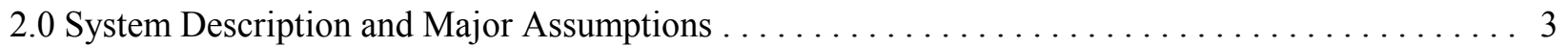

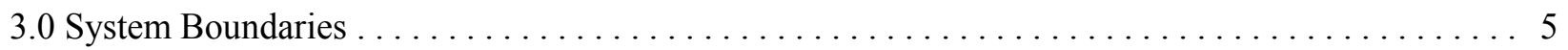

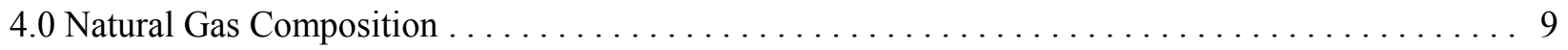

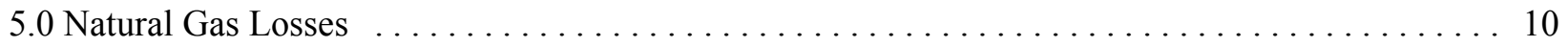

$6.0 \mathrm{NO}_{\mathrm{x}}$ Control: Water Injection and Selective Catalytic Reduction $\ldots \ldots \ldots \ldots \ldots \ldots \ldots \ldots \ldots$

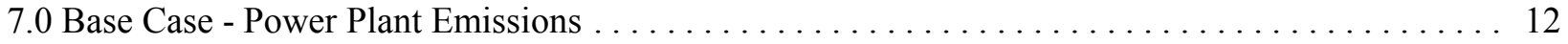

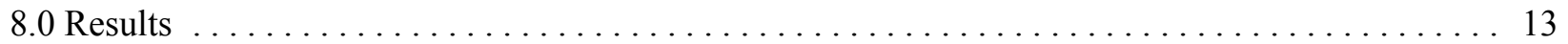

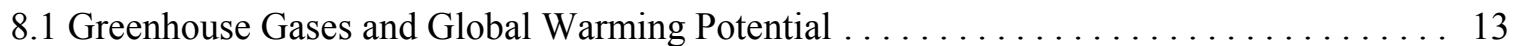

8.2 Air Emissions . . . . . . . . . . . . . . . . . . . . . . . . . . . . . . . . . 14

8.3 Energy Consumption and System Energy Balance $\ldots \ldots \ldots \ldots \ldots \ldots \ldots \ldots \ldots \ldots$

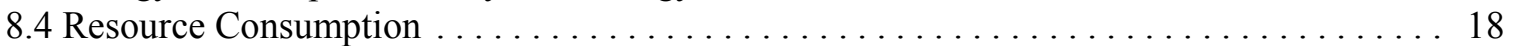

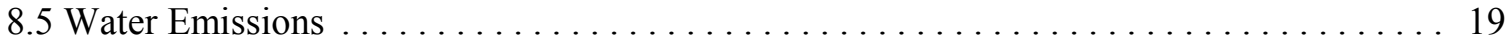

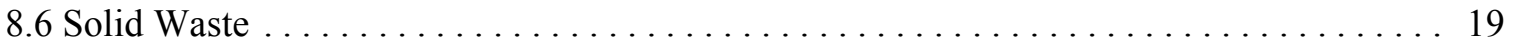

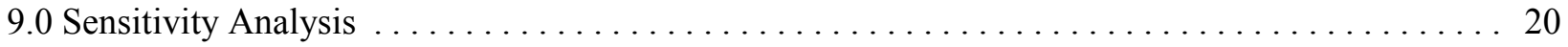

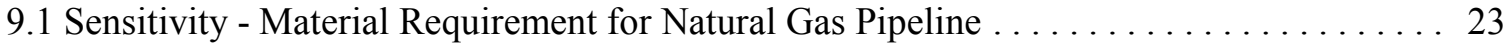

9.2 Sensitivity - Natural Gas Losses . . . . . . . . . . . . . . . . . . . . . . . . . . . . 23

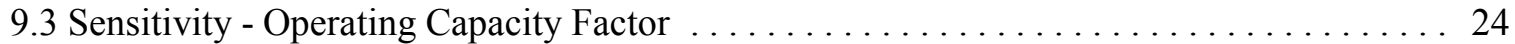

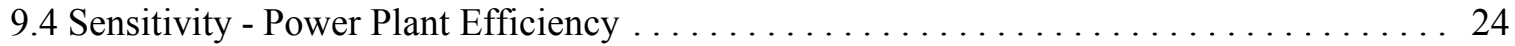

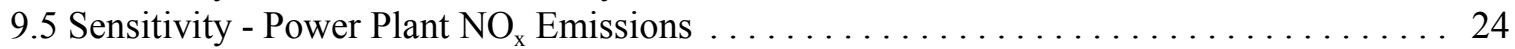

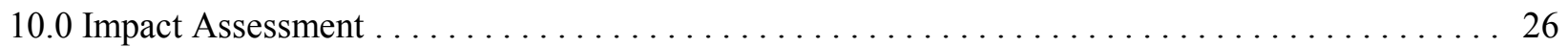

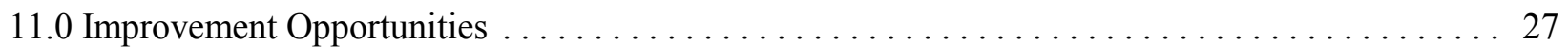

12.0 Other Life Cycle Assessments on Power Production via Natural Gas Combined-Cycle . . . . . 28

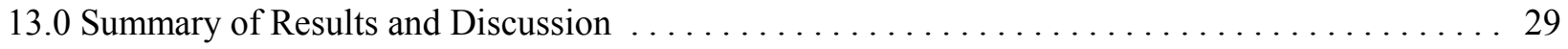

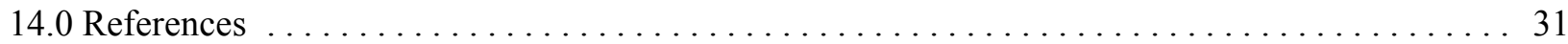

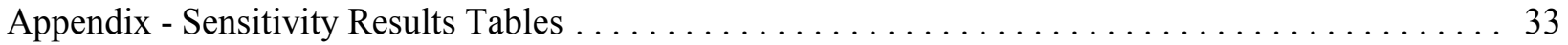




\section{List of Tables}

Table 1: Natural Gas Combine Cycle Power Plant Data $\ldots \ldots \ldots \ldots \ldots \ldots \ldots \ldots \ldots \ldots \ldots \ldots$

Table 2: Power Plant Material Requirements (Base Case) $\ldots \ldots \ldots \ldots \ldots \ldots \ldots \ldots \ldots \ldots$

Table 3: U.S. Natural Gas Pipeline Specifications $\ldots \ldots \ldots \ldots \ldots \ldots \ldots \ldots \ldots \ldots \ldots \ldots \ldots$

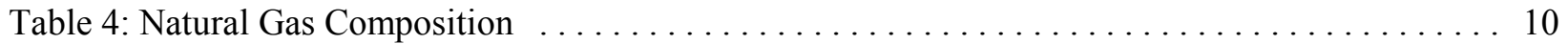

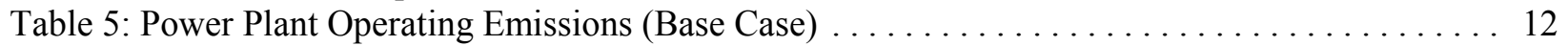

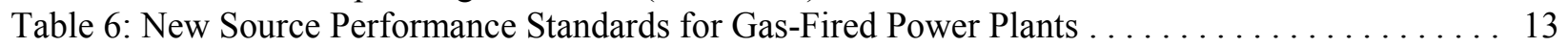

Table 7: Greenhouse Gas Emissions and Global Warming Potential . . . . . . . . . . . . . . . . . 14

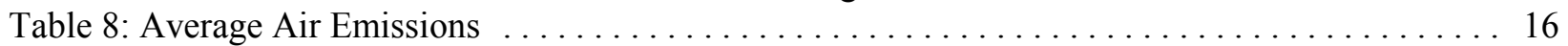

Table 9: Average Energy Requirements per kWh of Net Electricity Produced (LHV basis) . . . . . 17

Table 10: Energy Efficiency and Energy Ratio Definitions $\ldots \ldots \ldots \ldots \ldots \ldots \ldots \ldots \ldots \ldots \ldots 17$

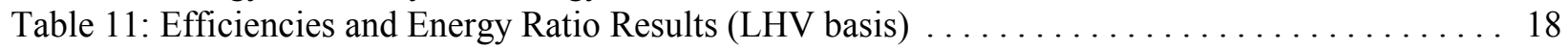

Table 12: Average Non-Renewable Resource Consumption per kWh of Net Electricity Produced . . . 18

Table 13: Breakdown of Resource Consumption for Power Plant and Pipeline . . . . . . . . . . . . 19

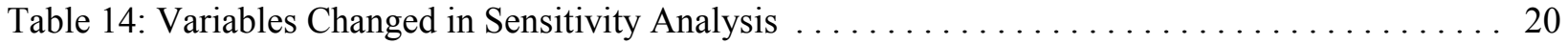

Table 15: Sources of Greenhouse Gases for Natural Gas Loss Sensitivity Cases . . . . . . . . . 23

Table 16: Impacts Associated with Stressor Categories $\ldots \ldots \ldots \ldots \ldots \ldots \ldots \ldots \ldots \ldots \ldots \ldots$

Table 17: Comparison of Major Results for Coal versus Natural Gas . . . . . . . . . . . . . . . 27

Table 18: Comparison of $\mathrm{NO}_{x}, \mathrm{SO}_{x}$, and Particulate Emission Levels . . . . . . . . . . . . . . 29

\section{List of Figures}

Figure 1: Natural Gas Combined-Cycle Plant Size Mix in Year $2004 \ldots \ldots \ldots \ldots \ldots \ldots \ldots \ldots \ldots .4$

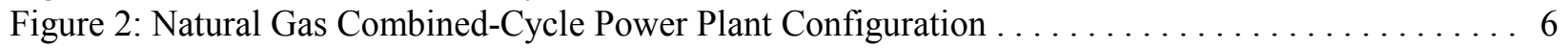

Figure 3: System Boundaries for Electricity Production via a Natural Gas Combined-Cycle Process . . 7

Figure 4: Life Cycle Global Warming Potential $\left(\mathrm{CO}_{2}\right.$-equivalent $) \ldots \ldots \ldots \ldots \ldots \ldots \ldots \ldots \ldots$

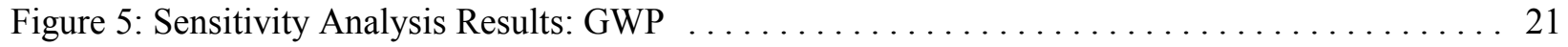

Figure 6: Sensitivity Analysis Results: Energy Balance $\ldots \ldots \ldots \ldots \ldots \ldots \ldots \ldots \ldots \ldots \ldots \ldots \ldots$ 


\section{Units of Measure}

Metric units of measure are used in this report. Therefore, material consumption is reported in units based on the gram (e.g., kilogram or megagram), energy consumption based on the joule (e.g., kilojoule or megajoule), and distance based on the meter (e.g., kilometer). When it can contribute to the understanding of the analysis, the English system equivalent is stated in parenthesis. The metric units used for each parameter are given below, with the corresponding conversion to English units.

Mass: $\quad$ kilogram $(\mathrm{kg})=2.205$ pounds

$$
\text { megagram }(\mathrm{Mg})=\text { metric tonne }(\mathrm{T})=1 \times 10^{6} \mathrm{~g}=1.102 \text { ton }(\mathrm{t})
$$

Distance: $\quad$ kilometer $(\mathrm{km})=0.62$ mile $=3,281$ feet

Area: $\quad$ hectare $(\mathrm{ha})=10,000 \mathrm{~m}^{2}=2.47$ acres

Volume: $\quad$ cubic meter $\left(\mathrm{m}^{3}\right)=264.17$ gallons

Pressure: $\quad$ kilopascals $(\mathrm{kPa})=0.145$ pounds per square inch

Energy: $\quad$ kilojoule $(\mathrm{kJ})=1,000$ Joules $(\mathrm{J})=0.9488 \mathrm{Btu}$

gigajoule $(\mathrm{GJ})=0.9488 \mathrm{MMBtu}($ million $\mathrm{Btu})$

kilowatt-hour $(\mathrm{kWh})=3,414.7 \mathrm{Btu}$

gigawatt-hour $(\mathrm{GWh})=3.4 \times 10^{9} \mathrm{Btu}$

Power: $\quad$ megawatt $(\mathrm{MW})=1 \times 10^{6} \mathrm{~J} / \mathrm{s}$

Temperature: $\quad{ }^{\circ} \mathrm{C}=\left({ }^{\circ} \mathrm{F}-32\right) / 1.8$ 


\section{Abbreviations and Terms}

AGA

Avoided stressor

Avoided operation

Btu

$\mathrm{CO}_{2}$-equivalence

CFR

DEAM

DOE

EIA

GRI

GWP

HHV

IPCC

$\mathrm{kWh}$

LAER

LCA

MW

$\mathrm{N}_{2} \mathrm{O}$

NMHCs

NSPS

$\mathrm{NO}_{\mathrm{x}}$

NREL

SCR

$\mathrm{SO}_{x}$

Stressor

Stressor category

TEAM $^{\circledR}$

UDI

U.S. DOE

U.S. EPA

VOC

vol $\%$

$\mathrm{wt} \%$
American Gas Association

an emission, energy use, or resource consumption that does not occur because the system of interest is operating

a process that normally would have taken place if the system of interest were not operating

British thermal units

Expression of the GWP in terms of $\mathrm{CO}_{2}$ for the following three components $\mathrm{CO}_{2}, \mathrm{CH}_{4}$, $\mathrm{N}_{2} \mathrm{O}$, based on IPCC weighting factors

Code of Federal Regulations

Data for Environmental Analysis and Management (also referred to as the TEAM ${ }^{\circledR}$ database)

United States Department of Energy

Energy Information Administration

Gas Research Institute

global warming potential, expressed as grams of $\mathrm{CO}_{2}$-equivalent

higher heating value

Intergovernmental Panel on Climate Change

kilowatt-hour (denotes energy)

lowest achievable emissions rate

life cycle assessment

megawatt (denotes power)

nitrous oxide

non-methane hydrocarbons, including VOCs

New Source Performance Standard

nitrogen oxides, $\left(\mathrm{NO}_{2}\right.$ and $\mathrm{NO}$, expressed as $\left.\mathrm{NO}_{2}\right)$

National Renewable Energy Laboratory

Selective catalytic reduction

sulfur oxides, expressed as $\mathrm{SO}_{2}$

A term that collectively defines emissions, resource consumption, and energy use; a substance or activity that results in a change to the natural environment

A grouping of stressors that defines and delineates impacts

Tools for Environmental Analysis and Management (software by Ecobalance, Inc.)

Utility Data Institute

United States Department of Energy

United States Environmental Protection Agency

volatile organic compound

percentage by volume

percentage by weight 


\subsection{Introduction}

Natural gas is an important fuel in the United States. It accounts for $22 \%$ of all the energy consumed in the U.S. and is used for steam and heat production in industrial processes, residential and commercial heating, and electric power generation (U.S. DOE, December 1998). Although coal is the feedstock used at the highest rate to produce power in the U.S., because natural gas is one of the cleanest burning fossil fuels, its role in electricity generation is becoming increasingly important. Currently, natural gas accounts for $9.9 \%$ of the fuel consumed in power production (U.S. DOE, July 1998), which results in $14.7 \%$ of the net electricity generated by the electric power industry. This can be compared to coal, which accounts for $56 \%$ of the fuel consumed in making electricity in the U.S. (U.S. DOE, July 1998), but results in $51.7 \%$ of the net electricity generated (including non-utility power producers). These numbers show that one advantage of natural gas systems is their higher conversion efficiencies compared to coal-fired power plants. Because electricity restructuring favors less capital-intensive, more efficient generation processes, electricity generated from natural gas is expected to grow from the current $14.7 \%$ to $33 \%$ by 2020 (U.S. DOE, December 1998).

Increasing the use of natural gas for electricity production can benefit the environment in many ways compared to electricity generated from other fossil fuels. Because natural gas has a lower sulfur and nitrogen content than coal, for example, using natural gas will result in fewer $\mathrm{SO}_{\mathrm{x}}$ and $\mathrm{NO}_{\mathrm{x}}$ emissions per $\mathrm{kWh}$ of electricity produced. Additionally, unlike coal-fired power plants, a natural gas combined-cycle (NGCC) system produces no large solid waste streams. The environmental consequences of a power generation facility, though, depend not only on the emissions from the plant, but also those that result from upstream operations such as fuel production and transportation.

This life cycle assessment was performed to quantify and analyze the environmental aspects of producing electricity from a NGCC power generation system, including all necessary upstream operations. The system was divided into the following process steps: construction and decommissioning of the power plant, construction of the natural gas pipeline, natural gas production and distribution, ammonia production and distribution for $\mathrm{NO}_{\mathrm{x}}$ removal, and power plant operation. In the near future, this LCA will be compared with previously performed LCAs for other electricity generation systems: biomass gasification combined-cycle, coal-fired power production, biomass cofiring in a coal-fired power plant, and direct-fired biomass power generation (Mann and Spath, 1997; Spath and Mann, 1999; Mann and Spath, 2000; and Spath and Mann, 2000). A report will be issued in late 2000 which examines the environmental benefits and drawbacks of the various electricity generating systems. However, it should be noted that because no operations that are common to the different systems were eliminated, the analysis of the NGCC system is complete, irrespective of the competing technologies.

\subsection{System Description and Major Assumptions}

The methodology for this LCA is the same as that used in LCAs earlier performed by the National Renewable Energy Laboratory (NREL) (Mann and Spath, 1997 and Spath and Mann, 1999). The NGCC system was modeled in GateCycle ${ }^{\mathrm{TM}}$, a software package which performs detailed steady-state and off-design analyses of thermal power systems. This software by Enter Software ${ }^{\mathrm{TM}}$ was specifically developed to help design and analyze combined-cycle and fossil boiler power plants. The software was used to obtain an energy balance and some of the material balance data for the power plant itself (see section 7.0 for details about the base case turbine emissions). The plant is assumed to be a baseload plant and the size was chosen to be around $500 \mathrm{MW}$, which is similar to the size of the plant studied in NREL's coal-fired power plant LCA (Spath and Mann, 1999). A large number of NGCC plants currently operating, being built, or planned are generally in the 100-500 MW size range. Figure 1, which contains data from the Utility Data Institute 
Figure 1: Natural Gas Combined-Cycle Plant Size Mix in 2004

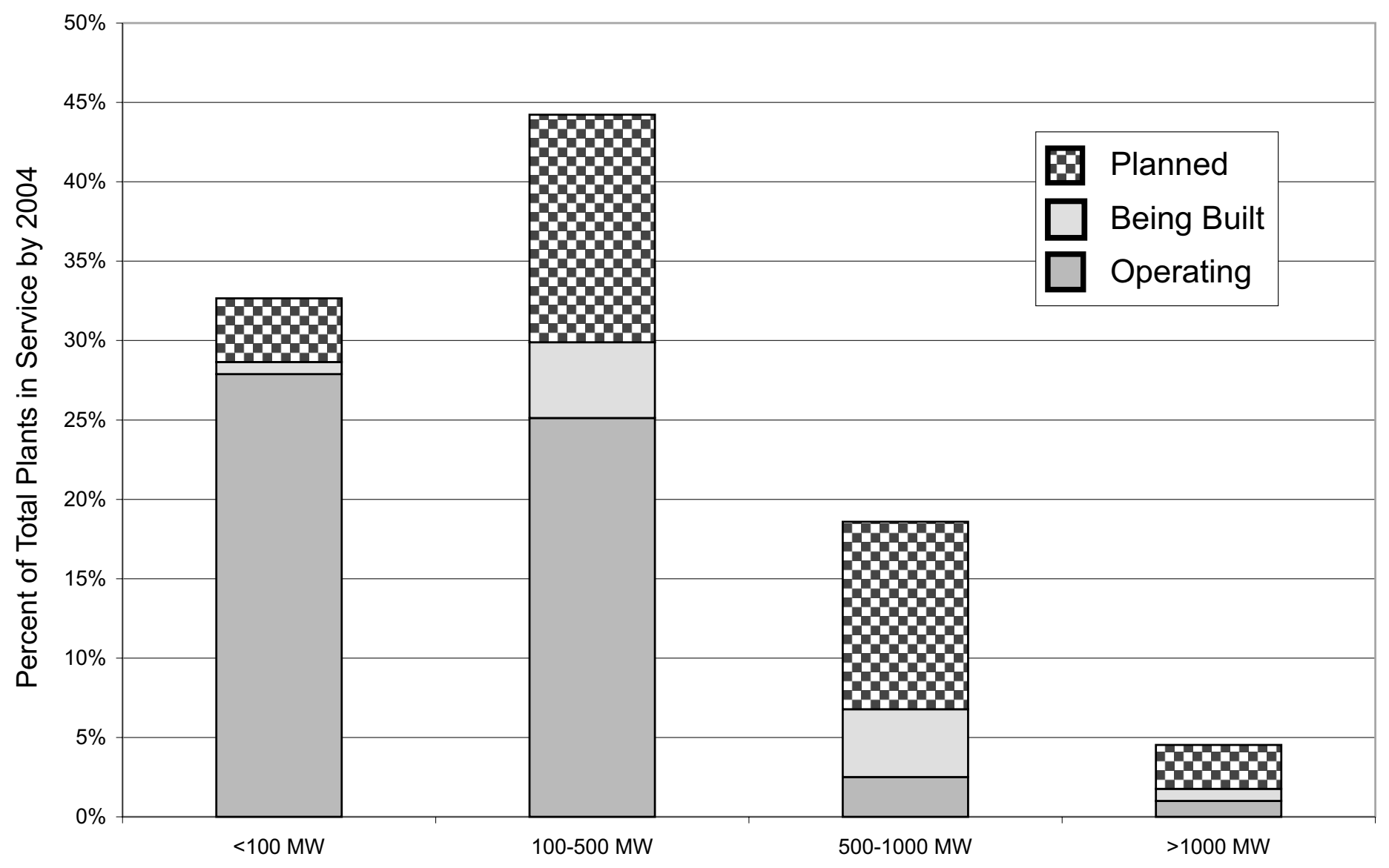


database, denotes this fact (UDI, 1999). This figure also shows that the trend is to build larger plants for future electricity generation.

The system in this study contains two Siemens Westinghouse W501F gas turbines, a three pressure heat recovery steam generator, and a condensing reheat steam turbine. In this analysis, the gas turbines are "data driven" and therefore use a set of vendor curves to determine their performance at a given set of operating conditions. Figure 2 shows the system configuration that was modeled in GateCycle ${ }^{\mathrm{TM}}$. Data from the UDI database shows Siemens Westinghouse W501 series turbine to be prominent in NGCC plants currently under construction. This series accounts for $34 \%$ of the total number of turbines listed in the database (taken from UDI, 1999). However, it is not clear which turbines will be used by future plants since almost all of the planned plants in this database have no designated turbine type or manufacturer. To minimize the power plant's $\mathrm{NO}_{\mathrm{x}}$ emissions, the power plant incorporates selective catalytic reduction (SCR) with water injection (see section 6.0). The system parameters for the power plant can be seen in Table 1.

Table 1: Natural Gas Combine Cycle Power Plant Data

\begin{tabular}{|l|c|}
\hline \multicolumn{1}{|c|}{ Design parameter } & Data \\
\hline Plant size & $505 \mathrm{MW}$ \\
\hline Net power from gas turbines (@100\% capacity) & $337 \mathrm{MW}$ \\
\hline Net power from steam cycle (@100\% capacity) & $168 \mathrm{MW}$ \\
\hline Natural gas feed rate @ 100\% operating capacity & $1,673 \mathrm{Mg} / \mathrm{day}$ \\
\hline Power plant efficiency (HHV basis) & $48.8 \%$ \\
\hline Net heat rate (HHV basis) & $7,378 \mathrm{~kJ} / \mathrm{kWh}$ \\
\hline Water injection ratio & $0.8 \mathrm{~kg} / \mathrm{kg} \mathrm{of} \mathrm{natural} \mathrm{gas}$ \\
\hline NO removal efficiency & $78 \%$ \\
\hline Ammonia injection ratio & $0.89{\mathrm{~mol} \mathrm{of} \mathrm{NH}_{3} / \mathrm{mol} \text { of }}^{\mathrm{NO}} \mathrm{removed}_{\mathrm{x}}$ \\
\hline Average operating capacity factor & $80 \%$ \\
\hline
\end{tabular}

\subsection{System Boundaries}

The software package used to track the material and energy flows between the process blocks within the system was Tools for Environmental Analysis and Management $\left(\mathrm{TEAM}^{\circledR}\right)$, by Ecobalance, Inc. Figure 3 shows the boundaries for the system. The solid lines in the figure represent actual material and energy flows; the dotted lines indicate logical connections between process blocks. The stressors associated with natural gas production and distribution, as well as those for ammonia production, were taken from the TEAM ${ }^{\circledR}$ database, known as Data for Environmental Analysis and Management (DEAM). The steps associated with obtaining the natural gas feedstock are drilling/extraction, processing, and pipeline transport. Processing includes glycol dehydration and gas sweetening using the amine process in which sulfur is recovered as elemental sulfur. The emissions associated with each process step in the natural gas production block were obtained through a joint study by Ecobalance and the Gas Research Institute (GRI). The ammonia production process assumes no $\mathrm{CO}_{2}$ recovery. In addition to being the feedstock, a significant amount of natural gas is required as fuel in the ammonia production block. This results in $60 \mathrm{wt} \%$ of the total natural gas into this process block being utilized for the feedstock while $40 \mathrm{wt} \%$ is consumed as fuel for the ammonia production. 
Figure 2: Natural Gas Combined-Cycle Power Plant Configuration

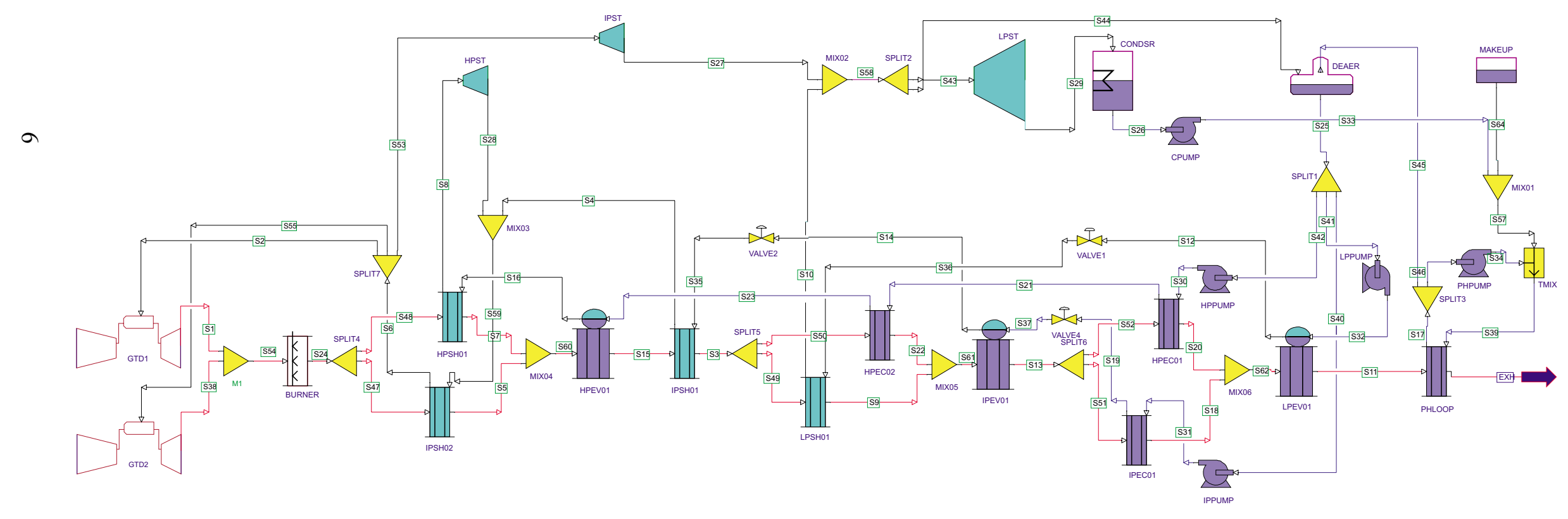




\section{Figure 3: System Boundaries for Electricity Production via a Natural Gas Combined-Cycle Process}

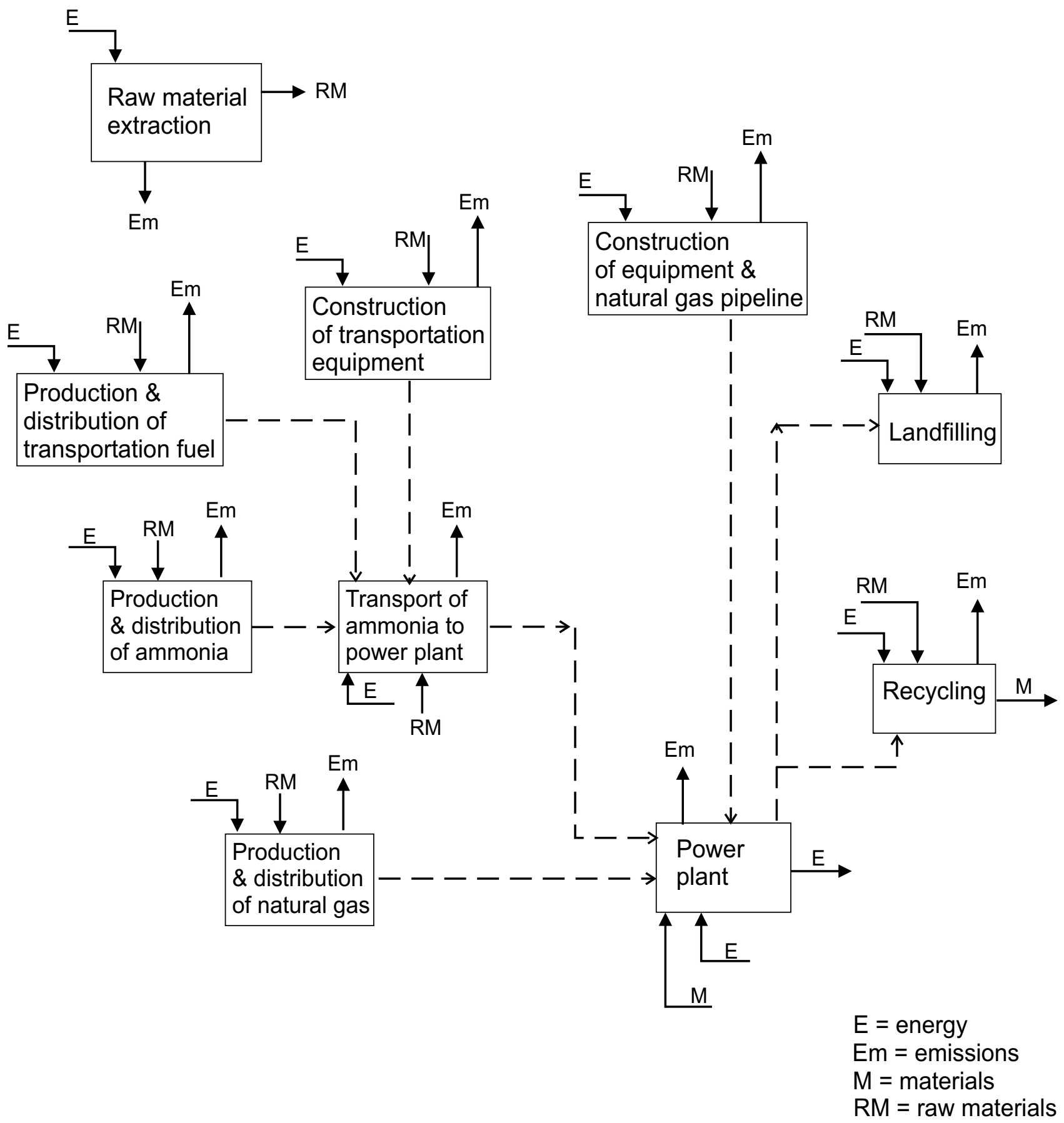


The ammonia must be transported from its production point to the power plant. The transportation requirements were assumed to be $60 \%$ by rail and $40 \%$ by truck over an average distance of $640 \mathrm{~km}$ (based on details gathered for NREL's biomass power LCA study) (Mann and Spath, 1997). Light fuel oil and diesel are used in the trains and trucks, respectively. The resources, energy, and emissions related to extracting crude oil, distilling it, producing a usable transportation fuel, and distributing it to refueling stations, plus the emissions produced during combustion of the fuel, were included in the total inventory. These data were taken from the DEAM database, of which some details are shown in Appendix B of NREL's biomass power LCA report (Mann and Spath, 1997). The material requirements for each of the various modes of transportation were used in determining the environmental stressors associated with vehicle production and decommissioning (for more details about these requirements refer to Mann and Spath, 1997).

For this study, the plant life was set at 30 years with 2 years of construction. In year one the power plant begins to operate; plant construction takes place in the two years prior to this (years negative two and negative one). In year one, the power plant is assumed to operate $40 \%$ of the time due to start-up activities ( $50 \%$ of the year at a capacity factor of $80 \%$ ). In years one through 29 , normal plant operation occurs with the plant operating at a capacity factor of $80 \%$. In year 30 , the power plant is decommissioned during the last quarter of that year. Therefore, the power plant will be in operation $60 \%$ of the last year $(75 \%$ of the year at a capacity factor of $80 \%$ ).

Methods for determining plant construction and decommissioning are the same as those used in NREL's past LCAs (see Mann and Spath, 1997 and Spath and Mann, 1999). Table 2 lists the power plant construction material requirements used in this study. These values were based on a study by DynCorp (1995) which examined power generation via a number of technologies, including a $200 \mathrm{MW}$ NGCC system.

Table 2: Power Plant Material Requirements (Base Case)

\begin{tabular}{|l|c|}
\hline \multicolumn{1}{|c|}{ Material } & $\begin{array}{c}\text { Amount required } \\
\text { (kg/MW of plant capacity) }\end{array}$ \\
\hline Concrete & 97,749 \\
\hline Steel & 31,030 \\
\hline Iron & 408 \\
\hline Aluminum & 204 \\
\hline
\end{tabular}

It was also assumed that with the significant amount of natural gas being consumed, additional pipelines would be required to move the natural gas from the oil or gas wells to the power plant. Ullmann's Encyclopedia of Industrial Chemistry (1986) states that typical pipe diameters in the natural gas industry are 60-110 centimeters (23.6-43.3 inches) and Kirk-Othmer's Encyclopedia of Chemical Technology (1993) lists a range of 36-142 centimeters (14.2-55.9 inches). For this analysis, the total length of pipeline transport is assumed to be $4,000 \mathrm{~km}(2,486 \mathrm{mi})$. The main pipeline diameter was set at 76.2 centimeters ( 30 inches $)$ and this main pipeline is assumed to extend $80 \%$ of the total distance or $3,200 \mathrm{~km}(1,988 \mathrm{mi})$. Because the main pipeline is shared by many users, only a portion (19.3\%) of the material requirement was allocated for the NGCC plant. To determine this percentage, the total flow through the $76.2 \mathrm{~cm}$ diameter pipe at a pressure drop of $0.05 \mathrm{psi} / 100$ feet $(0.00035 \mathrm{MPa} / 30$ meters $)$ was calculated then the required natural gas flow rate for this NGCC plant was divided by the total flow, which resulted in a value of $15.4 \%$. The remaining length of the total pipeline, $800 \mathrm{~km}$ (498 mi), was also sized so that the pressure drop through the pipe would not exceed $0.05 \mathrm{psi} / 100$ feet $(0.00035 \mathrm{MPa} / 30$ meters $)$. This resulted in a pipe diameter of 46 centimeters $(18$ inches). Thus, the total pipeline steel requirement for the power plant was $94,336 \mathrm{Mg}$ (103,988 tons), assuming a standard wall thickness. The process steps associated with producing the steel were included in the analysis. Due to a lack of data, no additional emissions for digging and laying the pipe were included 
in the analysis. Nevertheless, a sensitivity analysis was performed with different pipe diameters to determine the material requirement effect on the overall results (see section 9.1).

\subsection{Natural Gas Composition}

In general, natural gas is produced from gas or oil wells. Methane is the main component in natural gas, usually making up greater than $80 \mathrm{vol} \%$ of the constituents. The remaining constituents are ethane, propane, butane, hydrogen sulfide, and inerts (nitrogen, carbon dioxide, and helium). The amount of these compounds can vary greatly depending on the location of the wellhead. The gas almost always undergoes treatment prior to its use, which primarily means drying and sweetening. Most often, the gas is saturated with water vapor and glycol units can dehydrate the natural gas to a moisture content of $8 \mathrm{mg} / \mathrm{m}^{3}$ (Ullmann's Encyclopedia of Industrial Chemistry, 1986). Natural gas containing $\mathrm{H}_{2} \mathrm{~S}$ is sweetened, most commonly with the amine process, to reduce the $\mathrm{H}_{2} \mathrm{~S}$ concentration to less than 4 ppmv (Ullmann's Encyclopedia of Industrial Chemistry, 1986). To lower the amount of energy expended in transporting the natural gas stream, it is cost effective to minimize the levels of $\mathrm{CO}_{2}$ and $\mathrm{N}_{2}$. Additionally, $\mathrm{CO}_{2}$ is reduced to $1-2 \mathrm{vol} \%$ to curtail the amount of corrosion in the transmission systems (Ullmann's Encyclopedia of Industrial Chemistry, 1986). There are no universally accepted specifications for marketed natural gas; however, the U.S. standards are listed in Table 3 (taken from Ullmann's Encyclopedia of Industrial Chemistry, 1986).

Table 3: U.S. Natural Gas Pipeline Specifications

\begin{tabular}{|l|c|}
\hline \multicolumn{1}{|c|}{ Characteristic } & Specification \\
\hline Water content & $64-112 \mathrm{mg} / \mathrm{m}^{3}$ \\
\hline Hydrogen sulfide & $\begin{array}{l}5.7 \mathrm{mg} / \mathrm{m}^{3} \\
(4 \mathrm{ppmv})\end{array}$ \\
\hline Gross heating value & $35.4 \mathrm{MJ} / \mathrm{m}^{3}$ \\
\hline $\begin{array}{l}\text { Hydrocarbon dew point } \\
\text { at 5.6 MPa }\end{array}$ & $264.9 \mathrm{~K}$ \\
\hline Mercaptan content & $4.6 \mathrm{mg} / \mathrm{m}^{3}$ \\
\hline Total sulfur & $23-114 \mathrm{mg} / \mathrm{m}^{3}$ \\
\hline Carbon dioxide & $1-3 \mathrm{~mol} \%$ \\
\hline Oxygen & $0-0.4 \mathrm{~mol} \%$ \\
\hline
\end{tabular}

The base case of this LCA used the typical natural gas pipeline composition listed in the Chemical Economics Handbook (Lacson, 1999), which was adjusted to include $\mathrm{H}_{2} \mathrm{~S}$ (4 ppmv; based on the specifications above). The composition of the natural gas transported to the power plant is shown in Table 4. To show the diversification of natural gas compositions found throughout the world, the range of wellhead component values is also listed in Table 4. 
Table 4: Natural Gas Composition

\begin{tabular}{|c|c|c|c|}
\hline \multirow[t]{2}{*}{ Component } & \multirow{2}{*}{$\begin{array}{c}\text { Pipeline composition } \\
\text { used in analysis (a) } \\
\text { Mol \% (dry) }\end{array}$} & \multicolumn{2}{|c|}{$\begin{array}{l}\text { Typical range of wellhead } \\
\text { components (mol\%) (b) }\end{array}$} \\
\hline & & Low value & High value \\
\hline Carbon dioxide $\left(\mathrm{CO}_{2}\right)$ & 0.5 & 0 & 10 \\
\hline Nitrogen $\left(\mathrm{N}_{2}\right)$ & 1.1 & 0 & 15 \\
\hline Methane $\left(\mathrm{CH}_{4}\right)$ & 94.4 & 75 & 99 \\
\hline Ethane $\left(\mathrm{C}_{2} \mathrm{H}_{6}\right)$ & 3.1 & 1 & 15 \\
\hline Propane $\left(\mathrm{C}_{3} \mathrm{H}_{8}\right)$ & 0.5 & 1 & 10 \\
\hline Iso-butane $\left(\mathrm{C}_{4} \mathrm{H}_{10}\right)$ & 0.1 & 0 & 1 \\
\hline N-butane $\left(\mathrm{C}_{4} \mathrm{H}_{10}\right)$ & 0.1 & 0 & 2 \\
\hline Pentanes $+\left(\mathrm{C}_{5}^{+}\right)$ & 0.2 & 0 & 1 \\
\hline Hydrogen sulfide $\left(\mathrm{H}_{2} \mathrm{~S}\right)$ & 0.0004 & 0 & 30 \\
\hline Helium $(\mathrm{He})$ & 0.0 & 0 & 5 \\
\hline Heat of combustion, LHV & $\begin{array}{c}48,252 \mathrm{~J} / \mathrm{g} \\
(20,745 \mathrm{Btu} / \mathrm{lb})\end{array}$ & & 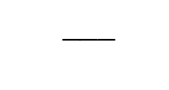 \\
\hline Heat of combustion, HHV & $\begin{array}{c}53,463 \mathrm{~J} / \mathrm{g} \\
(22,985 \mathrm{Btu} / \mathrm{lb})\end{array}$ & & \\
\hline
\end{tabular}

(a) Taken from Chemical Economics Handbook (Lacson, 1999) and adjusted to included $\mathrm{H}_{2} \mathrm{~S}$.

(b) Taken from Ullmann's Encyclopedia of Industrial Chemistry, 1986.

Changing the composition of the wellhead gas, other than the split of hydrocarbons, primarily affects the processing requirements prior to pipeline distribution. Individual energy and material balances could not be obtained for the glycol dehydration and amine gas sweetening steps; therefore, a sensitivity analysis, which varies the wellhead gas composition was not performed. Furthermore, from the DEAM database a breakdown of the stressors show that the majority come from extraction and pipeline transport and only a small fraction are the result of separation, dehydration, and sweetening. Changing the split of higher hydrocarbons versus $\mathrm{CH}_{4}$ will slightly change the energy and carbon balance of the power plant, but since natural gas is primarily made up of $\mathrm{CH}_{4}$ the changes will not be large enough to affect the overall results. To test this, a natural gas composition containing $80 \mathrm{vol} \%$ methane and roughly $20 \mathrm{vol} \%$ higher hydrocarbons (primarily ethane and propane) was put into the GateCycle ${ }^{\mathrm{TM}}$ model. The plant capacity decreased from 504.95 MW to 504.25 MW, the natural gas requirement increased $1 \%$ from 1,673 Mg/day to $1,692 \mathrm{Mg} /$ day, and the $\mathrm{CO}_{2}$ emissions increased by about $4 \%$. Therefore, it was not considered beneficial to perform a sensitivity analysis with different ratios of $\mathrm{CH}_{4}$ to higher hydrocarbons.

\subsection{Natural Gas Losses}

Over the past two decades, the natural gas industry and others have tried to better quantify the amount of $\mathrm{CH}_{4}$ emissions lost to the atmosphere during the extraction, processing, transmission, storage, and distribution of natural gas. There is a general consensus that fugitive emissions constitute the largest source, accounting for about $38 \%$ of the total, and that nearly $90 \%$ of the fugitive emissions are a result of leaking compressor components (Resch, 1995 and Harrison et al, 1997). The second largest source of $\mathrm{CH}_{4}$ emissions comes from pneumatic control devices, accounting for approximately $20 \%$ of the total (Resch, 1995). Pneumatic devices are a major emissions source in the extraction step. Engine exhaust is the third largest source of $\mathrm{CH}_{4}$ 
emissions due to incomplete combustion in reciprocating engines and turbines. Thus, these three sources make up nearly $75 \%$ of the overall estimated $\mathrm{CH}_{4}$ emissions (Resch, 1995; Harrison et al, 1997).

According to the United States Environmental Protection Agency (U.S. EPA), transmission and storage account for the largest portion of the total methane emissions at $37 \%$ followed by extraction at $27 \%$, distribution at $24 \%$, and processing contributing the least at $12 \%$ (Harrison et al, 1997). In the late 1980s EPA, GRI, and the American Gas Association (AGA) initiated a study which estimated the methane emitted to the atmosphere from U.S. natural gas operations to be $1.4 \%+/-0.5 \%$ of the gross natural gas produced (Harrison et al, 1997). Another publication (Kirchgessner et al, 1997) which includes several authors of the EPA/GRI/AGA study, states that numerous estimates of methane emissions are available and that the most commonly cited leakage rates range from 1-4\%. Following the U.S. EPA/GRI/AGA study, the Natural Gas STAR Program was launched in 1993. It is a voluntary program with the natural gas industry that is designed to reduce $\mathrm{CH}_{4}$ emissions through cost-effective measures. The program currently has more than 80 partners. Because this program is designed to keep the methane emissions to a minimum, the overall amount of methane lost to the atmosphere is actually expected to decrease as the natural gas industry grows. The base case of this LCA assumed that $1.4 \%$ of the natural gas that is produced is lost to the atmosphere due to fugitive emissions. To determine the effect that natural gas losses have on the results and specifically on the systems global warming potential (GWP), a sensitivity analysis was performed on this variable (see section 9.2). The natural gas production module in DEAM was altered so that it could accommodate different natural gas loss rates.

\section{0 $\mathrm{NO}_{\mathrm{x}}$ Control: Water Injection and Selective Catalytic Reduction}

To minimize $\mathrm{NO}_{\mathrm{x}}$ emissions, the power plant incorporates $\mathrm{SCR}$ with water injection. The water injection rate is $0.8 \mathrm{~kg} / \mathrm{kg}$ of natural gas. GateCycle ${ }^{\mathrm{TM}}$ has the capability to model water injection but not SCR, so external calculations were performed to estimate flue gas $\mathrm{NO}_{\mathrm{x}}$ levels. In the SCR unit, the $\mathrm{NO}_{\mathrm{x}}$ removal efficiency was assumed to be $78 \%$ (an industry average) and the molar ratio of ammonia injected to $\mathrm{NO}_{\mathrm{x}}$ removed is 0.89 based on data from three sources: Environmental Catalyst Consultants, Inc., 1992; SRI International,1989 and U.S. EPA, 1992.

SCR is frequently used to reduce flue gas $\mathrm{NO}_{x}$ emissions from power plants. In this process, ammonia $\left(\mathrm{NH}_{3}\right)$ is injected into the gas stream before the gas enters the catalyst bed. The ammonia reacts with the $\mathrm{NO}_{\mathrm{x}}$ in the presence of a catalyst to form water vapor and nitrogen. The chemistry can be represented by two reactions: $4 \mathrm{NO}+4 \mathrm{NH}_{3}+\mathrm{O}_{2}=>4 \mathrm{~N}_{2}+6 \mathrm{H}_{2} \mathrm{O}$ and $2 \mathrm{NO}_{2}+4 \mathrm{NH}_{3}+\mathrm{O}_{2}=>3 \mathrm{~N}_{2}+6 \mathrm{H}_{2} \mathrm{O}$. The base metal of the most common SCR catalysts is either vanadium, platinum, or titanium (Environmental Catalyst Consultants, 1992). Zeolites have also been demonstrated as effective catalysts. The SCR catalyst requires replacement every one to five years depending on the degree of sintering that occurs at the high reaction temperatures, plugging of pores due to solid deposits, and poisoning by alkali compounds or $\mathrm{SO}_{3}$ (Makansi 1988). Utilities have several options for handling spent catalyst. They can send it to a metals recovery facility for recycling, dispose of it in a landfill, or return it to the original catalyst supplier. It may be possible to regenerate the zeolite catalysts; however, the process is not yet commercial. Because a system design giving the amount of catalyst required could not be obtained for this LCA, the manufacture and disposal of the catalyst were not included. Although the amount of spent catalyst will be small and not produced continuously, this is the only solid waste stream from the power plant.

In general, the $\mathrm{SCR}$ catalyst promotes the conversion $\mathrm{SO}_{2}$ to $\mathrm{SO}_{3}$ in the presence of $\mathrm{O}_{2}$. The $\mathrm{SO}_{3}$ can then react with any residual $\mathrm{NH}_{3}$ to form ammonium sulfate and ammonium bisulfate which will deposit in downstream heat exchangers causing plugging problems (Makansi 1988). Therefore, it is important to control the amount of excess unreacted $\mathrm{NH}_{3}$. As the $\mathrm{SCR}$ catalyst deactivates, the $\mathrm{NH}_{3}$ slip (i.e., the $\mathrm{NH}_{3}$ that 
exits the SCR unit) increases. The catalyst is usually maintained or replaced periodically to keep the slip below $5 \mathrm{ppm}$ to minimize plugging problems and to maintain emissions below a regulated level (Environmental Catalyst Consultants, Inc., 1992). For this analysis, the ammonia slip was taken from EPA's emission data for stationary gas turbines (U.S. EPA 1995, section 3.1, Stationary Gas Turbines for Electricity Generation, "Emission Factors for Large Gas-Fired Controlled Gas Turbines"), which is 5.5 ppm for this system. Several sensitivity analyses were performed to examine different amounts of $\mathrm{NO}_{\mathrm{x}}$ from the power plant with and without $\mathrm{NO}_{\mathrm{x}}$ control (see section 9.5).

\subsection{Base Case - Power Plant Emissions}

As mentioned in section 2.0, GateCycle ${ }^{\mathrm{TM}}$ was used to obtain material balance data for the gas turbine. This software program does not account for $\mathrm{NO}_{\mathrm{x}}, \mathrm{SO}_{\mathrm{x}}$, or incomplete combustion, therefore, additional emission data were obtained from the references given in Table 5 . To balance the carbon atoms, the carbon emissions emitted from incomplete combustion $\left(\mathrm{CO}\right.$, and $\left.\mathrm{CH}_{4}\right)$ were subtracted from GateCycle's ${ }^{\mathrm{TM}} \mathrm{CO}_{2}$ emissions. Additionally, the non-methane hydrocarbons (NMHCs) and formaldehyde, which are results of the SCR process step, were also subtracted from GateCycle's ${ }^{\mathrm{TM}} \mathrm{CO}_{2}$ emissions. The ammonia and the $\mathrm{NO}_{\mathrm{x}}$ is the amount that slips through the SCR unit. All of the sulfur in the feed was converted to $\mathrm{SO}_{2}$.

Table 5: Power Plant Operating Emissions (Base Case)

\begin{tabular}{|l|r|r|}
\hline \multicolumn{1}{|c|}{ Compound } & $\begin{array}{c}\text { Emission amount } \\
(\mathrm{kg} / \mathrm{GWh})\end{array}$ & Reference \\
\hline Ammonia $\left(\mathrm{NH}_{3}\right)$ & 21 & U.S. EPA 1995 (a) \\
\hline Carbon dioxide $\left(\mathrm{CO}_{2}\right)$ & 371,247 & GateCycle - after adjustment \\
\hline Carbon monoxide $(\mathrm{CO})$ & 27 & U.S. EPA 1995 (a) \\
\hline Formaldehyde $\left(\mathrm{CH}_{2} \mathrm{O}\right)$ & 9 & U.S. EPA 1995 (a) \\
\hline Methane $\left(\mathrm{CH}_{4}\right)$ & 44 & U.S. EPA 1995 (a) \\
\hline Nitrogen oxides $\left(\mathrm{NO}_{x}\right.$ as $\left.\mathrm{NO}_{2}\right)$ & 95 & U.S. EPA 1995 (a) \\
\hline $\begin{array}{l}\text { Non-methane hydrocarbons } \\
\text { (NMHCs) }\end{array}$ & 10 & U.S. EPA 1995 (a) \\
\hline Particulates & 62 & U.S. EPA 1995 (b) \\
\hline Sulfur oxides $\left(\mathrm{SO}_{x}\right.$ as $\left.\mathrm{SO}_{2}\right)$ & 2 & U.S. EPA 1995 (a) \\
\hline
\end{tabular}

(a) Section 3.1 - Stationary Gas Turbines for Electricity Generation, "Emission Factors for Large Gas-Fired Controlled Gas Turbines," SCR with water injection

(b) Section 3.1 - Stationary Gas Turbines for Electricity Generation, "Emission Factors for Large Gas-Fired Uncontrolled Gas Turbines," PM-10, solids

Because no data could be found regarding particulate emissions from $\mathrm{NGCC}$ power plants with $\mathrm{NO}_{\mathrm{x}}$ control, the non-condensable particulate emissions for uncontrolled turbines were used in this study. The SCR catalyst bed will act as a filter for some of the particulates. However, catalyst fines will result in some particulate emissions, possibly canceling particulate reduction in the bed.

For this study, the NGCC power plant emissions are lower than those required by the New Source Performance Standards (NSPS) under the Code of Federal Regulations (CFR) for gas-fired power plants. Table 6 indicates the standards of performance for new electric utility steam generating units using gaseous fossil fuels (other than coal-derived gases) (40 CFR 60.42a, 60.43a, and 60.44a; Office of the Federal Register National Archives and Records Administration, 1996). New plants built after 1978 are required to 
meet these standards. The base case plant emissions are also shown in Table 6 for comparison. The emission rates listed in the $\mathrm{CFR}$ were converted to $\mathrm{kg} / \mathrm{GWh}$ for comparison to the base case values used in this LCA. Again, several sensitivity analyses were performed to examine different amounts of $\mathrm{NO}_{\mathrm{x}}$ from the power plant with and without $\mathrm{NO}_{\mathrm{x}}$ control (see section 9.5).

Table 6: New Source Performance Standards for Gas-Fired Power Plants

\begin{tabular}{|l|c|c|c|}
\hline \multirow{2}{*}{} & \multicolumn{2}{|c|}{ NSPS } & $\begin{array}{c}\text { Base case power plant } \\
\text { emissions }\end{array}$ \\
\cline { 2 - 4 } & $\begin{array}{c}\mathrm{g} / \mathrm{GJ} \text { heat input, HHV } \\
(\mathrm{lb} / \mathrm{MMBtu})\end{array}$ & $\begin{array}{c}\text { For this plant the NSPS would } \\
\text { result in an emission amount of } \\
(\mathrm{kg} / \mathrm{GWh})\end{array}$ & $(\mathrm{kg} / \mathrm{GWh})$ \\
\hline $\mathrm{NO}_{\mathrm{x}}$ & $86(0.2)$ & 634 & 95 \\
\hline $\mathrm{SO}_{\mathrm{x}}$ & $86(0.2)$ & 634 & 2 \\
\hline Particulates & $13(0.03)$ & 95 & 62 \\
\hline
\end{tabular}

Note: These standards do not apply to coal-derived gases.

\subsection{Results}

The following sections contain the results for the base case analysis, including air emissions, energy requirements, resource consumption, water emissions, and solid wastes. Most values are given in terms of the functional unit ( $\mathrm{kWh}$ of net electricity produced by the power plant), as averages over the life of the system so that the relative percent of emissions from each subsystem could be examined.

\subsection{Greenhouse Gases and Global Warming Potential}

The GWP of the system is defined as a combination of the following greenhouse gases: $\mathrm{CO}_{2}, \mathrm{CH}_{4}$, and $\mathrm{N}_{2} \mathrm{O}$. The capacities of $\mathrm{CH}_{4}$ and $\mathrm{N}_{2} \mathrm{O}$ to contribute to the warming of the atmosphere, are 21 and 310 times higher than $\mathrm{CO}_{2}$, respectively, for a 100 year time frame according to the IPCC (Houghton et al, 1996). Thus, the GWP of the system can be normalized to $\mathrm{CO}_{2}$-equivalence to describe its overall effect on global climate change. Table 7 contains the GWP as well as the net amount of greenhouse gases for this NGCC power generation system. $\mathrm{CO}_{2}$, which is emitted in the largest quantity $(99 \mathrm{wt} \%$ of the greenhouse gases listed in Table 7 as well as $99 \mathrm{wt} \%$ of the overall air emissions - see section 8.2 ), is responsible for $88.1 \%$ of the system GWP. Although the $\mathrm{CH}_{4}$ emitted from this system makes up only $0.6 \%$ of all greenhouse gases by weight, its higher radiative forcing factor causes it to be responsible for $11.6 \%$ of the total GWP. Nearly all of this methane is a result of natural gas losses during extraction and distribution (see section 8.2). 
Table 7: Greenhouse Gas Emissions and Global Warming Potential

\begin{tabular}{|l|c|c|c|c|c|}
\hline & $\begin{array}{c}\text { Emission } \\
\text { amount } \\
(\mathrm{g} / \mathrm{kWh})\end{array}$ & $\begin{array}{c}\text { Percent of } \\
\text { greenhouse gases } \\
\text { in this table (\%) }\end{array}$ & $\begin{array}{c}\text { GWP relative to } \mathrm{CO}_{2} \\
(100 \text { year IPCC } \\
\text { values })\end{array}$ & $\begin{array}{c}\text { GWP value } \\
\left(\mathrm{g} \mathrm{CO}_{2} \text {-equivalent } / \mathrm{kWh}\right)\end{array}$ & $\begin{array}{c}\text { Percent } \\
\text { contribution } \\
\text { to GWP (\%) }\end{array}$ \\
\hline $\begin{array}{l}\text { Total } \mathrm{CO}_{2} \\
\text { emissions }\end{array}$ & 439.7 & 99.4 & 1 & 439.7 & 88.1 \\
\hline $\begin{array}{l}\text { Total } \mathrm{CH}_{4} \\
\text { emissions }\end{array}$ & 2.8 & 0.6 & 21 & 59.2 & 11.9 \\
\hline $\begin{array}{l}\text { Total } \mathrm{N}_{2} \mathrm{O} \\
\text { emissions }\end{array}$ & 0.00073 & 0.0002 & 310 & 0.2 & 0.04 \\
\hline $\begin{array}{l}\text { Total system } \\
\text { GWP }\end{array}$ & N/A & N/A & N/A & 585.2 & N/A \\
\hline
\end{tabular}

In addition to showing the GWP in terms of individual greenhouse gases, the GWP of the system can also be divided among the different process steps. For this study, the overall system was broken out into construction and decommissioning, natural gas production and distribution, ammonia production and distribution, and power plant operation. Figure 4 shows these different process steps and their contribution to the overall GWP of the system. The power plant operating emissions, principally $\mathrm{CO}_{2}$, contribute the most to the GWP at $75 \%$. Because of the natural gas lost to the atmosphere (which is $1.4 \%$ of the gross natural gas production for the base case), the natural gas production and distribution block is responsible for $25 \%$ of the system's GWP. Changing the amount of natural gas lost has a significant effect on the GWP, as shown in section 9.2.

\subsection{Air Emissions}

As previously mentioned, $\mathrm{CO}_{2}$ is the air emission emitted in the largest quantity. Methane is emitted in the next highest quantity, and $74 \mathrm{wt} \%$ of the total methane emissions are fugitive emissions from natural gas production and distribution. Table 8 is a breakdown of the major air emissions and the percentage that comes from construction and decommissioning, natural gas production and distribution, ammonia production and distribution, and electricity generation. Excluding $\mathrm{CO}_{2}, \mathrm{CH}_{4}$ accounts for $58 \mathrm{wt} \%$ of the emissions, followed by NMHCs at $13 \mathrm{wt} \%, \mathrm{NO}_{\mathrm{x}}$ at $12 \mathrm{wt} \%, \mathrm{SO}_{\mathrm{x}}$ at $7 \mathrm{wt} \%$, and $\mathrm{CO}$ at $6 \mathrm{wt} \%$. 
Figure 4: Life Cycle Global Warming Potential

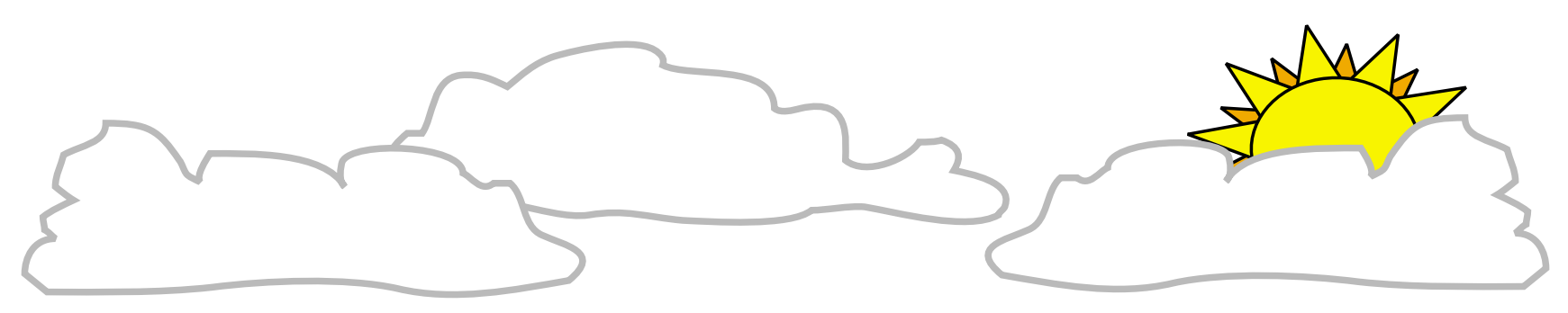

Net greenhouse gas emissions

$499.1 \mathrm{~g} \mathrm{CO}_{2}$-equivalent/kWh

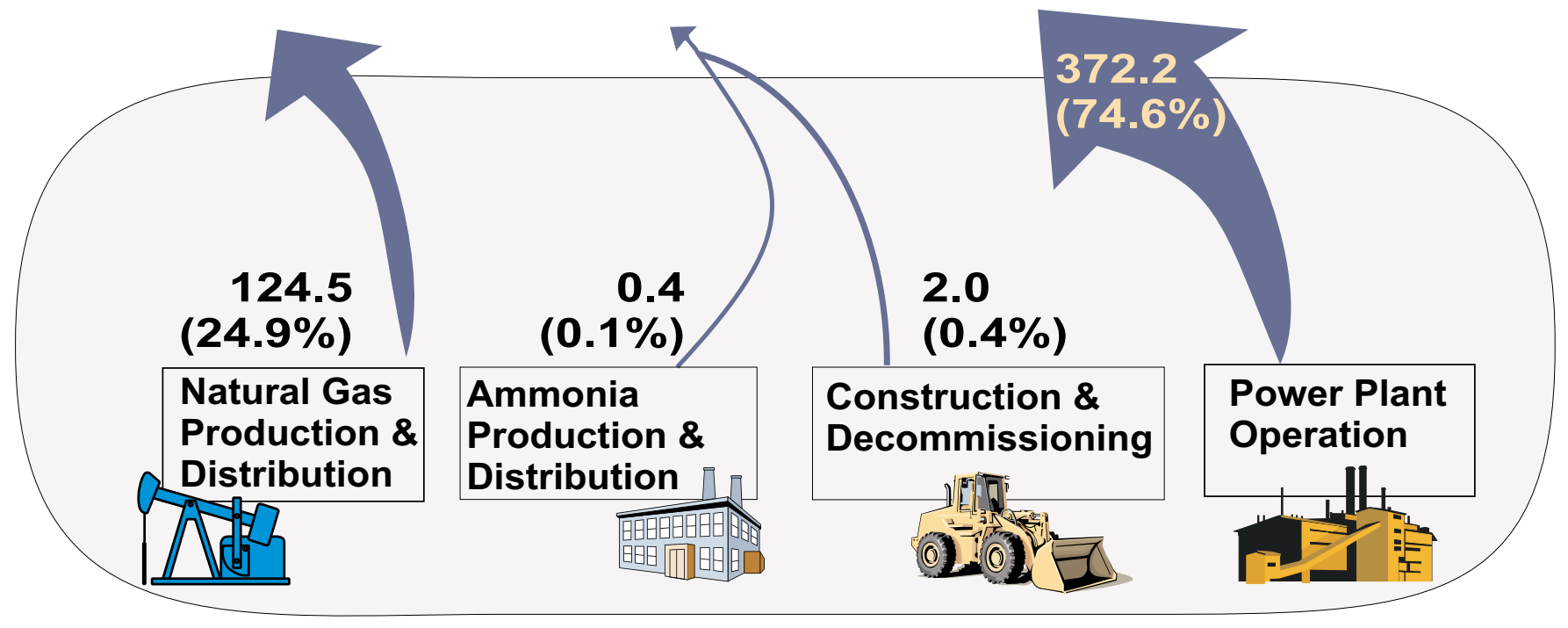


Table 8: Average Air Emissions

\begin{tabular}{|c|c|c|c|c|c|c|c|}
\hline $\begin{array}{l}\text { Air emission } \\
\text { (a) }\end{array}$ & $\begin{array}{l}\text { System } \\
\text { total } \\
(\mathrm{g} / \mathrm{kWh})\end{array}$ & $\begin{array}{l}\% \text { of } \\
\text { total in } \\
\text { this } \\
\text { table }\end{array}$ & $\begin{array}{l}\% \text { of } \\
\text { total in } \\
\text { this table } \\
\text { except } \\
\mathrm{CO}_{2}\end{array}$ & $\begin{array}{c}\% \text { of total from } \\
\text { construction \& } \\
\text { decommissioning } \\
\text { (b) }\end{array}$ & $\begin{array}{c}\% \text { of total } \\
\text { from natural } \\
\text { gas production } \\
\& \text { distribution }\end{array}$ & $\begin{array}{c}\% \text { of total } \\
\text { from ammonia } \\
\text { production \& } \\
\text { distribution }\end{array}$ & $\begin{array}{l}\% \text { of total } \\
\text { from } \\
\text { electricity } \\
\text { generation }\end{array}$ \\
\hline $\begin{array}{l}\text { Ammonia } \\
\left(\mathrm{NH}_{3}\right)\end{array}$ & $2.10 \mathrm{E}-02$ & $<0.0 \%$ & $0.4 \%$ & $0.2 \%$ & $0.0 \%$ & $1.6 \%$ & $98.2 \%$ \\
\hline $\begin{array}{l}\text { Benzene } \\
\left(\mathrm{C}_{6} \mathrm{H}_{6}\right)\end{array}$ & $6.32 \mathrm{E}-02$ & $<0.0 \%$ & $1.3 \%$ & $0.0 \%$ & $99.9 \%$ & $0.1 \%$ & $0.0 \%$ \\
\hline $\begin{array}{l}\text { Carbon } \\
\text { dioxide }\left(\mathrm{CO}_{2}\right)\end{array}$ & $4.40 \mathrm{E}+02$ & $98.9 \%$ & & $0.5 \%$ & $15.0 \%$ & $0.1 \%$ & $84.4 \%$ \\
\hline $\begin{array}{l}\text { Carbon } \\
\text { monoxide } \\
(\mathrm{CO})\end{array}$ & $2.87 \mathrm{E}-01$ & $0.1 \%$ & $5.9 \%$ & $1.6 \%$ & $88.6 \%$ & $0.5 \%$ & $9.3 \%$ \\
\hline $\begin{array}{l}\text { Hydrogen } \\
\text { sulfide }\left(\mathrm{H}_{2} \mathrm{~S}\right)\end{array}$ & $1.41 \mathrm{E}-08$ & $<0.0 \%$ & $<0.0 \%$ & $100.0 \%$ & $0.0 \%$ & $<0.0 \%$ & $<0.0 \%$ \\
\hline $\begin{array}{l}\text { Formaldehyde } \\
\left(\mathrm{CH}_{2} \mathrm{O}\right)\end{array}$ & $8.57 \mathrm{E}-03$ & $<0.0 \%$ & $0.2 \%$ & $0.0 \%$ & $0.0 \%$ & $0.0 \%$ & $100.0 \%$ \\
\hline $\begin{array}{l}\text { Methane } \\
\left(\mathrm{CH}_{4}\right)\end{array}$ & $2.82 \mathrm{E}+00$ & $0.6 \%$ & $58.1 \%$ & $<0.0 \%$ & $98.4 \%$ & $<0.0 \%$ & $1.6 \%$ \\
\hline $\begin{array}{l}\text { Nitrogen } \\
\text { oxides }\left(\mathrm{NO}_{\mathrm{x}} \text { as }\right. \\
\left.\mathrm{NO}_{2}\right)\end{array}$ & $5.70 \mathrm{E}-01$ & $0.1 \%$ & $11.7 \%$ & $1.6 \%$ & $81.5 \%$ & $0.1 \%$ & $16.7 \%$ \\
\hline $\begin{array}{l}\text { Nitrous oxide } \\
\left(\mathrm{N}_{2} \mathrm{O}\right)\end{array}$ & $7.19 \mathrm{E}-04$ & $<0.0 \%$ & $<0.0 \%$ & $19.4 \%$ & $80.2 \%$ & $0.5 \%$ & $0.0 \%$ \\
\hline $\begin{array}{l}\text { Non-methane } \\
\text { hydrocarbons } \\
\text { (NMHCs) }\end{array}$ & $6.28 \mathrm{E}-01$ & $0.1 \%$ & $12.9 \%$ & $2.3 \%$ & $95.8 \%$ & $0.2 \%$ & $1.6 \%$ \\
\hline Particulates & $1.33 \mathrm{E}-01$ & $<0.0 \%$ & $2.7 \%$ & $38.0 \%$ & $15.6 \%$ & $<0.0 \%$ & $46.4 \%$ \\
\hline $\begin{array}{l}\text { Sulfur oxides } \\
\left(\mathrm{SO}_{\mathrm{x}} \text { as } \mathrm{SO}_{2}\right)\end{array}$ & $3.24 \mathrm{E}-01$ & $0.1 \%$ & $6.7 \%$ & $15.4 \%$ & $83.8 \%$ & $0.2 \%$ & $0.6 \%$ \\
\hline
\end{tabular}

(a) Because of significant figures some of the percentages in this table are not actually zero and therefore are denoted as less than zero percent.

(b) The construction and decommissioning subsystem includes power plant construction and decommissioning as well as construction of the natural gas pipeline.

\subsection{Energy Consumption and System Energy Balance}

Table 9 shows the energy balance for the NGCC system (LHV basis). The majority, $80 \%$, of the total energy consumed is that contained in the natural gas feedstock. The upstream fossil energy, which accounts for $21 \%$ of the total energy consumption, includes the energy of the natural gas that is lost to the atmosphere. Although not listed separately in Table 9, this energy loss is equal to $0.11 \mathrm{MJ} / \mathrm{kWh}$ or $1.4 \%$ of the total energy consumed by the system. 
Table 9: Average Energy Requirements per kWh of Net Electricity Produced (LHV basis)

\begin{tabular}{|l|r|r|r|r|r|}
\hline & $\begin{array}{c}\text { System } \\
\text { total } \\
(\mathrm{MJ} / \mathrm{kWh})\end{array}$ & $\begin{array}{c}\% \text { of } \\
\text { total in } \\
\text { this } \\
\text { table }\end{array}$ & $\begin{array}{c}\% \text { of total from } \\
\text { construction \& } \\
\text { decommissioning } \\
\text { (a) }\end{array}$ & $\begin{array}{c}\% \text { of total from } \\
\text { natural gas } \\
\text { production, } \\
\text { distribution, } \\
\text { and use }\end{array}$ & $\begin{array}{c}\text { \% of total from } \\
\text { ammonia } \\
\text { production \& } \\
\text { distribution }\end{array}$ \\
\hline $\begin{array}{l}\text { Energy in the natural gas to } \\
\text { power plant }\end{array}$ & 6.7 & $79.5 \%$ & $\mathrm{~N} / \mathrm{A}$ & $100.0 \%$ & $\mathrm{~N} / \mathrm{A}$ \\
\hline $\begin{array}{l}\text { Non-feedstock energy } \\
\text { consumed by system (b) }\end{array}$ & 1.7 & $20.5 \%$ & $1.4 \%$ & $97.9 \%$ & $0.5 \%$ \\
\hline $\begin{array}{l}\text { Total energy consumed by } \\
\text { system }\end{array}$ & 8.4 & $\mathrm{~N} / \mathrm{A}$ & $\mathrm{N} / \mathrm{A}$ & $\mathrm{N} / \mathrm{A}$ & $\mathrm{N} / \mathrm{A}$ \\
\hline
\end{tabular}

(a) The construction and decommissioning subsystem includes power plant construction and decommissioning as well as construction of the natural gas pipeline.

(b) Excludes the energy in the natural gas feedstock energy but includes the energy in the natural gas lost to the atmosphere during natural gas production.

The energy use within the system was tracked so the net energy production could be assessed. Several types of efficiencies can be defined to study the energy budget. As stated earlier, the power plant efficiency for this NGCC system is $48.8 \%$ (HHV basis). This is defined as the energy to the grid divided by the energy in the natural gas feedstock to the power plant. Four other types of efficiencies/energy ratios can be defined as follows:

Table 10: Energy Efficiency and Energy Ratio Definitions

\begin{tabular}{|c|c|c|c|}
\hline Life cycle efficiency (\%) (a) & $\begin{array}{c}\text { External energy } \\
\text { efficiency (\%) (b) }\end{array}$ & Net energy ratio (c) & External energy ratio (d) \\
\hline$=\frac{E g-E u-E n}{E n}$ & $=\frac{E g-E u}{E n}$ & $=\frac{E g}{E f f}$ & $=\frac{E g}{E f f-E n}$ \\
\hline where: & $\begin{array}{l}\text { Eg = electric energy delivered to the utility grid } \\
\text { Eu = energy consumed by all upstream processes required to operate power plant } \\
\\
\text { En = energy contained in the natural gas fed to the power plant } \\
\text { Eff = fossil fuel energy consumed within the system (e) }\end{array}$ \\
\hline
\end{tabular}

(a) Includes the energy consumed by all of the processes.

(b) Excludes the heating value of the natural gas feedstock from the life cycle efficiency formula.

(c) Illustrates how much energy is produced for each unit of fossil fuel energy consumed.

(d) Excludes the energy of the natural gas to the power plant.

(e) Includes the natural gas fed to the power plant since this resource is consumed within the boundaries of the system.

The net energy ratio is a more accurate and rigorous measure of the net energy yield from the system than the external energy ratio because it accounts for all of the fossil energy inputs. However, the external definitions give a better understanding of upstream energy consumption. It is important to have these four definitions because the fossil fuel fed to the power plant overshadows the energy consumption from other process steps. Table 11 contains the resulting efficiencies and energy ratios for the system; given on a LHV basis. 
Table 11: Efficiencies and Energy Ratio Results (LHV basis)

\begin{tabular}{|c|c|c|c|c|}
\hline \multicolumn{1}{|c|}{ System } & $\begin{array}{c}\text { Life cycle } \\
\text { efficiency (\%) }\end{array}$ & $\begin{array}{c}\text { External energy } \\
\text { efficiency (\%) }\end{array}$ & $\begin{array}{c}\text { Net energy } \\
\text { ratio }\end{array}$ & $\begin{array}{c}\text { External } \\
\text { energy ratio }\end{array}$ \\
\hline $\begin{array}{l}\text { Natural gas } \\
\text { combined-cycle }\end{array}$ & $-70.1 \%$ & $29.9 \%$ & 0.4 & 2.2 \\
\hline
\end{tabular}

Because the natural gas is not a renewable source, the life cycle efficiency (which gives the total energy balance for the system) is negative, indicating that more energy is consumed by the system than is produced in the form of electricity. Excluding the consumption of the natural gas feedstock, the low values of the external energy efficiency and the external energy ratio indicate that upstream processes are large consumers of energy. Although not derived from the information in Table 11, disregarding the energy in the natural gas feedstock, $98 \%$ of the total energy consumption comes from natural gas production and distribution (see Table 9). This process block can be further broken up into natural gas extraction, processing, transmission, storage, and distribution. Of these, the largest consumers of energy are the natural gas extraction and pipeline transport steps. Diesel oil is combusted to meet the energy requirements of the drilling equipment, while pipeline transport uses a combination of grid electricity and natural gas to move the natural gas from its point of origin to its destination. Additionally, the net energy ratio in the table above shows that for every MJ of fossil energy consumed $0.4 \mathrm{MJ}$ of electricity are produced.

\subsection{Resource Consumption}

As one would expect, natural gas is consumed at the highest rate, accounting for nearly $98 \mathrm{wt} \%$ of the total resources. This is followed by coal, iron ore plus scrap, oil, and limestone. Table 12 shows the amount of resources consumed per kWh and the percentage from the different process steps. Practically all of the iron and limestone are used in the construction of the power plant and pipeline, while the vast majority of the coal and oil are consumed during the production and distribution of the natural gas.

Table 12: Average Non-Renewable Resource Consumption per kWh of Net Electricity Produced

\begin{tabular}{|c|c|c|c|c|c|}
\hline $\begin{array}{l}\text { Resource } \\
\text { (a) }\end{array}$ & $\begin{array}{c}\text { System } \\
\text { Total } \\
(\mathrm{g} / \mathrm{kWh})\end{array}$ & $\begin{array}{c}\% \text { of total } \\
\text { in this table }\end{array}$ & $\begin{array}{l}\% \text { of total from } \\
\text { construction \& } \\
\text { decommissioning } \\
\text { (b) }\end{array}$ & $\begin{array}{c}\% \text { of total from } \\
\text { natural gas } \\
\text { production \& } \\
\text { distribution }\end{array}$ & $\begin{array}{l}\% \text { of total from } \\
\text { ammonia } \\
\text { production \& } \\
\text { distribution }\end{array}$ \\
\hline Natural gas (in ground) & 169.2 & $97.6 \%$ & $0.0 \%$ & $99.9 \%$ & $0.1 \%$ \\
\hline Coal (in ground) & 1.8 & $1.0 \%$ & $33.8 \%$ & $65.5 \%$ & $0.7 \%$ \\
\hline Oil (in ground) & 0.6 & $0.4 \%$ & $32.2 \%$ & $67.7 \%$ & $0.2 \%$ \\
\hline Iron scrap & 0.6 & $0.4 \%$ & $100.0 \%$ & $0.0 \%$ & $<0.0 \%$ \\
\hline Iron $(\mathrm{Fe}$, ore $)$ & 0.6 & $0.3 \%$ & $100.0 \%$ & $0.0 \%$ & $<0.0 \%$ \\
\hline $\begin{array}{l}\text { Limestone }\left(\mathrm{CaCO}_{3} \text {, }\right. \\
\text { in ground) }\end{array}$ & 0.6 & $0.4 \%$ & $100.0 \%$ & $0.0 \%$ & $<0.0 \%$ \\
\hline
\end{tabular}

(a) Because of significant figures some of the percentages in this table are not actually zero and therefore are denoted as less than zero percent.

(b) The construction and decommissioning subsystem includes power plant construction and decommissioning as well as construction of the natural gas pipeline. 
The resources consumed during construction and decommissioning can be further broken into those required for constructing and decommissioning the power plant and those required for construction of the pipeline. The results of this breakdown are shown in Table 13. Other than limestone and oil, the majority of the resources are consumed during pipeline construction. This is due to the large steel requirement for the pipeline network $(94,336 \mathrm{Mg})$ versus the steel and even total material requirement (concrete, steel, iron, and aluminum) for the power plant $(15,639 \mathrm{Mg}$ of steel and $65,213 \mathrm{Mg}$ of total materials). A large amount of limestone is consumed for cement manufacture for plant construction.

Table 13: Breakdown of Resource Consumption for Power Plant and Pipeline

\begin{tabular}{|l|r|r|}
\hline \multicolumn{1}{|c|}{ Resource } & $\begin{array}{c}\text { \% of total from } \\
\text { power plant } \\
\text { construction \& } \\
\text { decommissioning }\end{array}$ & $\begin{array}{c}\% \text { of total } \\
\text { from pipeline } \\
\text { construction }\end{array}$ \\
\hline Natural gas (in ground) & $<0.0 \%$ & $<0.0 \%$ \\
\hline Coal (in ground) & $6.0 \%$ & $27.7 \%$ \\
\hline Oil (in ground) & $25.1 \%$ & $7.1 \%$ \\
\hline Iron scrap & $5.5 \%$ & $94.5 \%$ \\
\hline Iron (Fe, ore) & $5.7 \%$ & $94.3 \%$ \\
\hline Limestone (CaCO $\mathrm{CO}_{3}$, in ground) & $91.1 \%$ & $8.9 \%$ \\
\hline
\end{tabular}

Note: Because of significant figures some of the percentages in this table are not actually zero and therefore are denoted as less than zero percent.

\subsection{Water Emissions}

Similar to the findings of previously performed LCAs at NREL, the total amount of water pollutants was found to be small compared to other emissions. The total amount of water pollutants for this study is 0.01 $\mathrm{g} / \mathrm{kWh}$. The two main pollutants are oils and dissolved matter, accounting for $57 \mathrm{wt} \%$ and $23 \mathrm{wt} \%$, respectively, of the total water pollutants. The oils come primarily from natural gas production and distribution while the dissolved matter is produced from the material manufacturing steps involved in pipeline and power plant construction.

\subsection{Solid Waste}

About $94 \mathrm{wt} \%$ percent of the total waste for this system comes from the natural gas production and distribution block. Upon further examination, it is evident that most of the waste (65\% of the total waste) comes from pipeline transport and that the second largest waste source is natural gas extraction $(29 \%$ of the total waste). Even though the majority of the pipeline compressors are driven by reciprocating engines and turbines which are fueled by the natural gas, there are some electrical machines and electrical requirements at the compressor stations. The waste due to pipeline transport is a result of this electricity requirement. Since most of the electricity in the U.S. is generated from coal-fired power plants (51.7\%) (U.S. DOE, July 1998), the majority of the waste will be in the form of coal ash and flue gas clean-up waste. Although this study did not account for any solid wastes from the natural gas power plant itself, it should be noted that the only waste stream from the plant will be a small amount of spent catalyst generated every one to five years from the SCR unit. 


\subsection{Sensitivity Analysis}

A sensitivity analysis was conducted to examine the effect of varying the base case assumptions for several parameters. Table 14 shows the cases that were studied. Previous LCAs conducted by NREL examined more variables, including the amount of materials used or recycled in plant construction/decommissioning and the production and decommissioning of transportation vehicles and other equipment. Because the impact of these variables on the results of those studies was not found to be significant, they were not restudied here.

Table 14: Variables Changed in Sensitivity Analysis

\begin{tabular}{|c|c|c|c|}
\hline Variable & Base case & Sensitivity analysis cases & Case reference name \\
\hline \multirow{2}{*}{$\begin{array}{l}\text { Materials requirement for } \\
\text { natural gas pipeline }\end{array}$} & \multirow{2}{*}{$\begin{array}{c}94,336 \mathrm{Mg} \text { of } \\
\text { steel }\end{array}$} & decrease by $20 \%$ & pipeline_low \\
\hline & & increase by $20 \%$ & pipeline_high \\
\hline \multirow[t]{2}{*}{ Natural gas losses } & \multirow{2}{*}{$\begin{array}{l}1.4 \% \text { of the gas } \\
\text { removed from } \\
\text { the ground }\end{array}$} & $0.5 \%$ & ng_loss_low \\
\hline & & $4 \%$ & ng_loss_high \\
\hline \multirow[t]{3}{*}{ Operating capacity factor } & \multirow[t]{3}{*}{0.80} & 0.75 & cap_factor_75 \\
\hline & & 0.90 & cap_factor_90 \\
\hline & & 0.95 & cap_factor_95 \\
\hline \multirow[t]{2}{*}{ Power plant efficiency } & \multirow[t]{2}{*}{$\begin{array}{l}48.8 \% \\
\text { (HHV basis) }\end{array}$} & $\begin{array}{c}\text { decrease by } 5 \text { points to } 43.8 \% \\
\text { (HHV basis) }\end{array}$ & efficiency_low \\
\hline & & $\begin{array}{l}\text { increase by } 5 \text { points to } 53.8 \% \\
\text { (HHV basis) }\end{array}$ & efficiency_high \\
\hline \multirow[t]{6}{*}{ Power plant $\mathrm{NO}_{\mathrm{x}}$ emissions } & \multirow{6}{*}{$\begin{array}{l}9.4 \text { ppm out of } \\
\text { stack }\end{array}$} & 43 ppm (SCR not used) & $\mathrm{NO}_{\mathrm{x} \_}$Case 1 \\
\hline & & $\begin{array}{l}2 \text { ppm (LAER limit, new catalytic } \\
\text { technology) }\end{array}$ & $\mathrm{NO}_{\mathrm{x} \_} \mathrm{Case} 2$ \\
\hline & & 63 ppm (NSPS limit, no SCR) & $\mathrm{NO}_{x} \_$Case 3 \\
\hline & & $\begin{array}{l}16 \mathrm{ppm} \\
\text { (Average turbine emissions, } 72 \mathrm{ppm}) \\
\quad \text { (SRI International, 1989) }\end{array}$ & $\mathrm{NO}_{\mathrm{x} \_} \mathrm{Case} 4$ \\
\hline & & $\begin{array}{l}\quad 35 \mathrm{ppm} \\
\text { (High turbine emissions, } 160 \mathrm{ppm} \\
\text { (SRI International, 1989), SCR) }\end{array}$ & $\mathrm{NO}_{x \_} \_$Case 5 \\
\hline & & $\begin{array}{l}\qquad 20 \mathrm{ppm} \\
\text { (Low turbine emissions, no SCR) }\end{array}$ & $\mathrm{NO}_{\mathrm{x} \_} \mathrm{Case} 6$ \\
\hline
\end{tabular}

Figures 5 and 6 show the results for total GWP and system energy balance, respectively. As expected, because the natural gas used by the power plant represents the largest source of greenhouse gases (see Figure 4) and the largest consumer of energy (see Table 9), the efficiency sensitivity cases result in significant changes to GWP and energy balance. Varying the natural gas loss also has a large effect on system GWP because of the higher radiative forcing potential of $\mathrm{CH}_{4}$ compared to $\mathrm{CO}_{2}$. Changes in other stressors (e.g., total air emissions, resource consumption, etc.) are generally less dramatic because system operation is so heavily dominated by natural gas production and consumption. The tabulated results from all sensitivity cases can be found in the Tables in the Appendix. For those instances where there was meaningful variance from the base case results, more detail is given in the following sections. 
Figure 5: Sensitivity Analysis Results: GWP

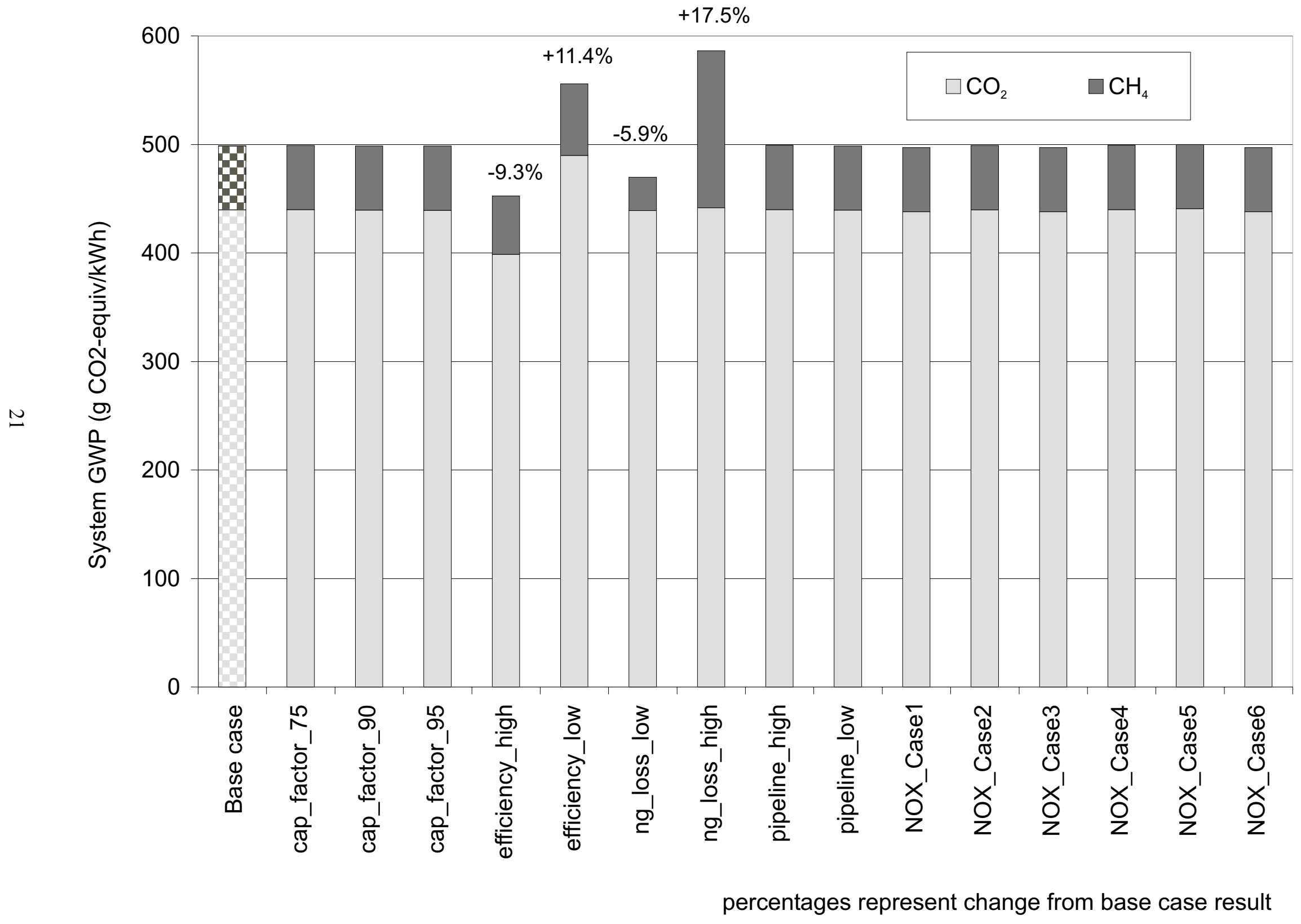


Figure 6: Sensitivity Analysis Results: Energy Balance

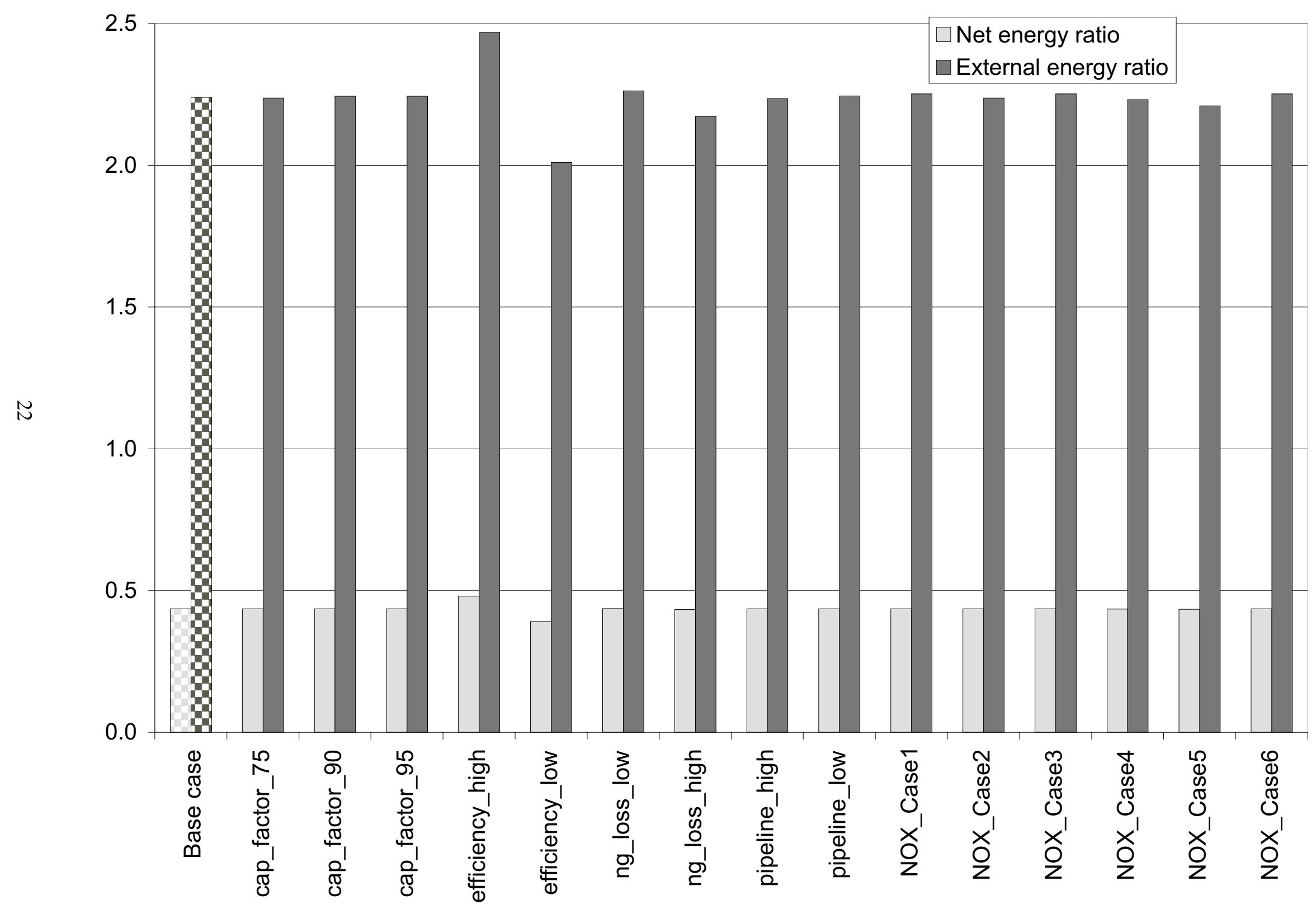




\subsection{Sensitivity - Material Requirement for Natural Gas Pipeline}

Because the amount of steel required to construct a new natural gas pipeline is significantly more than that required for building the power plant, the pipeline construction was deemed to be important enough to vary in a sensitivity analysis. Changing the amount of steel required by $+/-20 \%$ resulted in very small changes to the total stressors from the system. Although $\mathrm{N}_{2} \mathrm{O}$ emissions changed by $+/-3 \%$, the GWP of the system varied by less than $1 / 10$ th of a percent. The energy results also changed only slightly with this parameter, due to the fact that most of the energy consumed by the system is contained in the natural gas used at the power plant. Most air emissions change very slightly, although $\mathrm{H}_{2} \mathrm{~S}$ emissions change by $+/-15 \%$ from the base case because of the sulfur emitted during steel manufacturing. However, $\mathrm{H}_{2} \mathrm{~S}$ makes up a negligible amount of the total air emissions, even when $\mathrm{CO}_{2}$ is excluded (see Table 8). Iron and iron scrap requirements change by $+/-19 \%$, which is not insignificant given that this is the construction material used in the greatest amount. Changing the pipeline also changes the coal requirements somewhat $(+/-6 \%)$ because of the coke used to manufacture steel. The amount of waste generated changes only slightly.

\subsection{Sensitivity - Natural Gas Losses}

The natural gas losses were decreased from $1.4 \%$ of the total amount of gas pulled from the ground to $0.5 \%$ based on data from a study by U.S. EPA/GRI/AGA (Harrison et al, 1997; section 5.0). They were also increased to $4 \%$ to account for higher numbers that have been reported (Kirchgessner et al, 1997). It is unlikely that natural gas losses will be higher than $4 \%$ because of the implementation of the STAR program (see section 5.0).

Because of the higher global warming potential of $\mathrm{CH}_{4}$, the system GWP was significantly affected by changes in the natural gas loss. A $0.5 \%$ loss results in a $6 \%$ decrease in the GWP from the base case result. Increasing the natural gas losses to $4 \%$ increases the system GWP by $18 \%$. Table 15 shows the total GWP and sources of greenhouse gases for the base case and natural gas loss sensitivity cases.

Table 15: Sources of Greenhouse Gases for Natural Gas Loss Sensitivity Cases

\begin{tabular}{|l|c|c|c|c|c|}
\hline & $\begin{array}{c}\text { System GWP } \\
\text { (g CO }_{2} \\
\text { equivalent/kWh) }\end{array}$ & $\begin{array}{c}\text { \% from construction } \\
\text { (power plant and } \\
\text { pipeline })\end{array}$ & $\begin{array}{c}\text { \% from natural } \\
\text { gas production } \\
\text { and distribution }\end{array}$ & $\begin{array}{c}\text { \% from } \\
\text { ammonia } \\
\text { production }\end{array}$ & $\begin{array}{c}\text { \% from } \\
\text { power plant }\end{array}$ \\
\hline $\begin{array}{l}\text { Base Case } \\
(1.4 \% \text { loss })\end{array}$ & 499.1 & 0.4 & 24.9 & 0.1 & 74.6 \\
\hline $\begin{array}{l}\text { ng_loss_low } \\
(0.5 \% \text { loss })\end{array}$ & 469.9 & 0.4 & 20.2 & 0.1 & 79.2 \\
\hline $\begin{array}{l}\text { ng_loss_high } \\
(4 \% \text { loss })\end{array}$ & 586.6 & 0.4 & 36.1 & 0.1 & 63.5 \\
\hline
\end{tabular}

Total energy results for these sensitivity cases varied only slightly, as did most air emissions. However, emissions of $\mathrm{CH}_{4}$ and NMHCs changed in proportion to the amount of natural gas lost, as natural gas is primarily comprised of methane, ethane, plus some propane and other hydrocarbons (see Table 4). Changes in resources consumed reflect the need for more or less natural gas extraction to meet the demand at the power plant. Total waste generated changed by only a small amount. 


\subsection{Sensitivity - Operating Capacity Factor}

The capacity factor at which the plant operates was varied to $75 \%, 90 \%$, and $95 \%$, from the base case assumption of $80 \%$. Since the electricity generated from this plant will likely be among the cheapest available in many regions, and since this is a base load plant (i.e., not a peaking plant) it's likely that the actual operating capacity factor will be high. Thus, a case lower than $75 \%$ was not deemed to be probable. Additionally, a capacity factor higher than $95 \%$ is unlikely given the need for routine maintenance and mechanical failure, although these will be minimal for such a system.

The GWP and energy balance results for these sensitivity cases do not vary much from the base case results. Although $\mathrm{H}_{2} \mathrm{~S}$ varies by the greatest amount, as pointed out in section 9.1, above, this gas contributes such a small quantity to the total air emissions of the system that the importance of such a variance is small. Other air emissions that vary are $\mathrm{NO}_{\mathrm{x}}, \mathrm{SO}_{\mathrm{x}}$, and particulates.

\subsection{Sensitivity - Power Plant Efficiency}

Varying the power plant efficiency has the largest overall effect on the results of the study. All air emissions vary by $+11.4 \%$ and $-9.3 \%$ for +5 and -5 percentage points, respectively. Resource consumption and waste generation also changed by these amounts.

Life cycle efficiency and net energy ratio vary by $+/-7.9 \%$ and $+/-10.2 \%$, respectively for the efficiency cases studied. The external energy efficiency changed by $+/-19.0 \%$, further demonstrating that upstream energy consumption is high for this system. The fact that power plant efficiency has the largest effect on the results, shows that developing technologies designed to increase efficiency is the most effective strategy for reducing the impact on the environment from power production.

\subsection{Sensitivity - Power Plant NO Emissions}

Thermal $\mathrm{NO}_{\mathrm{x}}$ is typically formed at high temperatures, in the neighborhood of $1,204{ }^{\circ} \mathrm{C}\left(2,200{ }^{\circ} \mathrm{F}\right)$ (Schultz and Kitto, 1992). The higher the gas turbine combustion temperature, the more thermal $\mathrm{NO}_{\mathrm{x}}$ produced. Because models to predict generation of thermal $\mathrm{NO}_{\mathrm{x}}$ by the gas turbine are often inaccurate, several sensitivity cases were run. Cases were designed to compare systems with and without $\mathrm{NO}_{\mathrm{x}}$ control, low $\mathrm{NO}_{\mathrm{x}}$ formation, control by water/steam injection, and control with SCR. Statistics from the UDI database show that currently $55 \%$ of today's operating NGCC plants have some type of $\mathrm{NO}_{\mathrm{x}}$ control, while $23 \%$ of today's plants have steam injection only, and $22 \%$ have SCR by itself or combined with a low $\mathrm{NO}_{\mathrm{x}}$ burner or water injection (Utility Data Institute, 1999). Of the plants that are currently being constructed, 33\% are incorporating some combination of low $\mathrm{NO}_{\mathrm{x}}$ burners and SCR. Most of the plants being built are in Texas ( $26 \%$ of the total plants under construction) and Massachusetts ( $10 \%$ of the total plants under construction). Of the total number of planned plants, $12 \%$ will be in California, $11 \%$ in Texas, $8 \%$ in Florida, followed by $6 \%$ in Massachusetts and 6\% in Arizona. Almost all of the planned plants have nothing listed for $\mathrm{NO}_{\mathrm{x}}$ control; however, with the strict $\mathrm{NO}_{\mathrm{x}}$ regulations implemented by many states, these plants are expected to at least use low $\mathrm{NO}_{\mathrm{x}}$ burners and/or SCR.

The base case assumes that the gas turbine exhaust contains $43 \mathrm{ppm} \mathrm{NO}$, and that an SCR unit with a removal efficiency of $78 \%$ is used to reduce this level to $9.4 \mathrm{ppm}$ prior to releasing it from the plant. The ammonia required to operate the SCR unit is equal to 0.89 moles $\mathrm{NH}_{3}$ per mole of $\mathrm{NO}_{\mathrm{x}}$, or $9.1 \mathrm{moles} /$ hour that the system operates. Water injection in the gas turbine combustor is assumed to be used in the base case and in all sensitivity cases to reduce $\mathrm{NO}_{\mathrm{x}}$ formation. However, the lower flame temperature that results from the presence of increased water will cause higher $\mathrm{CO}, \mathrm{CH}_{4}$, and $\mathrm{NMHC}$ emissions compared to a turbine 
without water injection. The use of SCR, though, will reduce the concentration of these compounds in the flue gas, although data could only be found for CO. For the three $\mathrm{NO}_{\mathrm{x}}$ sensitivity cases that do not use SCR (cases 1, 3, and 6), the CO emissions were taken from AP-42 (U.S. EPA, 1995; section 3.1, Stationary Gas Turbines for Electricity Generation, "Emission Factors for Large Gas-Fired Controlled Gas Turbines") for water injection only ( $888 \mathrm{~kg} / \mathrm{GWh}$ versus $27 \mathrm{~kg} / \mathrm{GWh}$ for the base case). Not using SCR causes CO emissions to nearly triple for the overall system from $0.29 \mathrm{~g} / \mathrm{kWh}$ to $1.15 \mathrm{~g} / \mathrm{kWh}$. This is due to a 33 -fold increase in the power plant $\mathrm{CO}$ emissions.

For all $\mathrm{NO}_{\mathrm{x}}$ cases, the GWP and energy value results vary only slightly, as do the resources consumed and the waste generated. Stressors that changed are the air emissions that are directly associated with $\mathrm{NO}_{\mathrm{x}}$ formation and gas clean-up $\left(\mathrm{NH}_{3}, \mathrm{CO}\right.$, formaldehyde, and $\left.\mathrm{NO}_{\mathrm{X}}\right)$. Depending on whether or not SCR is used, and how much ammonia is required, ammonia emissions in the flue gas vary from case to case. Emissions of CO also change according to the use of the SCR technology.

\section{NO $O_{x}$ Case1:}

$\mathrm{NO}_{\mathrm{x}_{-}}$Case 1 assumes that the SCR unit is not used, making the $\mathrm{NO}_{\mathrm{x}}$ emissions from the plant equal to those coming from the gas turbine $(43 \mathrm{ppm})$. This case was derived from the fact that this level of turbine $\mathrm{NO}_{\mathrm{x}}$ is lower than NSPS regulations $(63 \mathrm{ppm})$. It's important to note, however, that individual state regulations may require emissions substantially lower than this level. This case, as well as $\mathrm{NO}_{x_{-}}$Case3, merely test the levels that might be emitted were NSPS to be followed. Without the SCR, production, use, and fugitive emissions of ammonia are eliminated.

\section{NO Case2:}

$\mathrm{NO}_{x_{-}}$Case2 represents the current lowest achievable emissions rate (LAER), 2 ppm, which is possible using a precious metal-based catalytic system developed by ABB Group. Because of its proprietary nature, data on this technology were not available. Therefore, SCR with higher ammonia requirements, was used to bring $\mathrm{NO}_{\mathrm{x}}$ emissions down to this level. System $\mathrm{NO}_{\mathrm{x}}$ emissions for this case are reduced by $13 \%$ from the base case.

\section{NO $\mathrm{x}_{\text {C Case3: }}$}

$\mathrm{NO}_{x}$ Case 3 assumes that $\mathrm{NO}_{\mathrm{x}}$ levels from the gas turbine are equal to those required under NSPS requirements $(63 \mathrm{ppm})$ and that SCR was not used. Power plant ammonia usage is then eliminated and total CO emissions are higher because of lost reductions in the SCR unit.

\section{NO Case4:}

$\mathrm{NO}_{\mathrm{x}}$ Case4 takes the average turbine emissions reported in SRI (1989), which are $72 \mathrm{ppm} \mathrm{NO}$, and reduces them to $16 \mathrm{ppm}$ using an SCR unit with a removal efficiency of $78 \%$. Because more $\mathrm{NO}_{\mathrm{x}}$ is being removed by this unit, the ammonia requirements are increased over the base case.

\section{NO ${ }_{x}$ Case 5:}

$\mathrm{NO}_{x_{-}}$Case 5 assumes that an SCR unit, with a $78 \%$ removal efficiency, is used to reduce $\mathrm{NO}_{\mathrm{x}}$ from the high turbine emissions reported in SRI (1989). As with $\mathrm{NO}_{x_{-}}$Case4, an increased rate of ammonia use is required to treat more $\mathrm{NO}_{\mathrm{x}}$ coming from the turbine.

\section{NO ${ }_{x}$ Case6:}

$\mathrm{NO}_{\mathrm{x}-}$ Case 6 was chosen based on the low end of the range of turbine emissions reported in SRI (1989). Beyond water injection, no $\mathrm{NO}_{\mathrm{x}}$ control was assumed. 


\subsection{Impact Assessment}

Life cycle impact assessment is a means of examining and interpreting the inventory data from an environmental perspective. There are several options for analyzing the system's impact on the environment and human health. To meet the needs of this study, categorization and less-is-better approaches have been taken. See SETAC $(1997,1998)$ for additional details about the different methods available for conducting impact assessments. Table 16 summarizes the stressor categories and main stressors from the NGCC system. A discussion of these stressor categories as well as information about the known effects of these stressors can be found in Spath and Mann (1999).

Table 16: Impacts Associated with Stressor Categories

\begin{tabular}{|c|c|c|c|c|}
\hline \multicolumn{2}{|c|}{ Stressor categories } & \multirow[t]{2}{*}{ Stressors } & \multirow{2}{*}{$\begin{array}{c}\text { Major impact } \\
\text { category } \\
\mathrm{H}=\text { human health } \\
\mathrm{E}=\text { ecological } \\
\text { health }\end{array}$} & \multirow{2}{*}{$\begin{array}{c}\text { Area impacted } \\
\mathrm{L}=\text { local (county) } \\
\mathrm{R}=\text { regional (state) } \\
\mathrm{G}=\text { global }\end{array}$} \\
\hline Major & Minor & & & \\
\hline $\begin{array}{l}\text { Ozone depletion } \\
\text { compounds }\end{array}$ & & NO & $\mathrm{H}, \mathrm{E}$ & $\mathrm{R}, \mathrm{G}$ \\
\hline \multirow[t]{2}{*}{ Climate change } & Greenhouse gases & $\begin{array}{l}\mathrm{CO}_{2}, \mathrm{CH}_{4}, \mathrm{~N}_{2} \mathrm{O}, \mathrm{CO} \\
\text { and } \mathrm{NO}_{\mathrm{x}} \text { (indirectly - } \\
\text { see note), water } \\
\text { vapor, sulfates }\end{array}$ & $\mathrm{H}, \mathrm{E}$ & $\mathrm{R}, \mathrm{G}$ \\
\hline & & Particulates & $\mathrm{H}, \mathrm{E}$ & $\mathrm{L}, \mathrm{R}$ \\
\hline Contributors to smog & Photochemical & $\mathrm{NO}_{\mathrm{x}}$, VOCs & $\mathrm{H}, \mathrm{E}$ & $\mathrm{L}, \mathrm{R}$ \\
\hline $\begin{array}{l}\text { Acidification } \\
\text { precursors }\end{array}$ & & $\mathrm{SO}_{2}, \mathrm{NO}_{\mathrm{x}}, \mathrm{CO}_{2}$ & $\mathrm{H}, \mathrm{E}$ & $\mathrm{L}, \mathrm{R}$ \\
\hline $\begin{array}{l}\text { Contributors to } \\
\text { corrosion }\end{array}$ & & $\begin{array}{l}\mathrm{NH}_{3}, \mathrm{NH}_{4}^{+} \text {salts, } \mathrm{SO}_{2}, \\
\mathrm{H}_{2} \mathrm{~S}, \mathrm{H}_{2} \mathrm{O}, \mathrm{HCl}\end{array}$ & $\mathrm{E}$ & $\mathrm{L}$ \\
\hline $\begin{array}{l}\text { Other stressors with } \\
\text { toxic effects }\end{array}$ & & NMHCs, benzene & $\mathrm{H}, \mathrm{E}$ & $\mathrm{L}$ \\
\hline Resource depletion & & $\begin{array}{l}\text { Fossil fuels, water, } \\
\text { minerals, and ores }\end{array}$ & $\mathrm{E}$ & $\mathrm{R}, \mathrm{G}$ \\
\hline Solid waste & & $\begin{array}{l}\text { Catalysts, coal ash, } \\
\text { flue gas clean up } \\
\text { waste }\end{array}$ & $\mathrm{H}, \mathrm{E}$ & $\mathrm{L}, \mathrm{R}$ \\
\hline
\end{tabular}

Note: $\mathrm{CO}$ and $\mathrm{NO}_{\mathrm{x}}$, although not typically referred to as greenhouse gases, are also included as climate change gases in this table. This is because they directly influence the atmospheric concentrations of actual greenhouse gases (IEA/OECD, 1991). For example, a molecule of carbon monoxide may react with a hydroxyl radical to form carbon dioxide. Also, both carbon monoxide and nitrogen oxides are involved in the production of tropospheric ozone. 


\subsection{Improvement Opportunities}

Another component of LCA, known as improvement, is used to identify opportunities for reducing the environmental impact of the system. The sensitivity analysis indicates that the largest environmental gains would be achieved by an increase in the power plant efficiency. Per $\mathrm{kWh}$ of net electricity produced, increasing the efficiency reduces all system stressors (resources, emissions, waste, and energy use). This, in turn, results in a lower GWP and higher energy ratios (meaning that more electricity is produced per unit of fossil fuel consumed). Some advances in gas turbine efficiency are expected in the future, however, it should be noted that NGCC is the most efficient, cost-effective large-scale generation technology today.

Another improvement that would change the GWP of the system is a reduction in the natural gas losses. The base case analysis shows that $12 \%$ of the GWP is a result of methane emissions and $74 \mathrm{wt} \%$ of the total system methane comes from natural gas lost during production and distribution. If the losses were reduced from $1.4 \%$ to $0.5 \%$, methane would account for about $7 \%$ of the GWP instead of $12 \%$. Reducing the natural gas losses will also improve the energy balance of the system. Depending on the composition of the natural gas, approximately 48,000 J of energy are lost per gram of natural gas that leaks to the atmosphere (LHV basis). In the base case, this translates to 0.03 units of energy lost per unit of energy delivered to the grid (i.e., $0.032 \mathrm{~J}$ natural gas / J electricity, or 3.2\%). Decreasing the loss to $0.5 \%$ reduces this source of energy loss to $0.011 \mathrm{~J}$ natural gas / J electricity. As discussed in section 5.0, the Natural Gas STAR Program is an industry consortium working to reduce methane emissions from natural gas production and distribution.

A feasible and economical option for reducing the environmental impact of the power industry, is to displace electricity from coal-fired power plants with that from NGCC systems. Because of the differences in feedstock composition, coal plants are noted for producing more $\mathrm{CO}_{2}, \mathrm{SO}_{\mathrm{x}}, \mathrm{NO}_{\mathrm{x}}$, and particulates, in addition to a large amount of waste (ash and flue gas clean-up waste) per kWh of electricity produced. Table 17 compares results of an average coal-fired power plant from NREL's previous LCA (Spath and Mann, 1999) with this study, including the percent of the total emissions that are emitted from the power plant itself. DOE's Energy Information Administration has predicted a jump in electricity from natural gas from the current $14.7 \%$ to $33 \%$ by 2020 (U.S. DOE, December 1998). This is due primarily to the lower investment cost per MW of capacity for NGCC plants compared to other options. Additionally, the lower levels of criteria air pollutants result in lower capital and operating expenses associated with meeting air quality regulations.

Table 17: Comparison of Major Results for Coal versus Natural Gas

\begin{tabular}{|l|c|c|c|c|}
\hline & $\begin{array}{c}\text { Coal-fired } \\
\text { system } \\
\text { emissions } \\
\text { (average plant) }\end{array}$ & $\begin{array}{c}\% \text { from power } \\
\text { plant }\end{array}$ & $\begin{array}{c}\text { Natural gas } \\
\text { combined-cycle } \\
\text { system } \\
\text { emissions }\end{array}$ & $\begin{array}{c}\% \text { from power } \\
\text { plant }\end{array}$ \\
\hline $\mathrm{NO}_{\mathrm{x}}(\mathrm{kg} / \mathrm{GWh})$ & 3,352 & $91 \%$ & 750 & $17 \%$ \\
\hline $\mathrm{SO}_{\mathrm{x}}(\mathrm{kg} / \mathrm{GWh})$ & 6,700 & $96 \%$ & 324 & $0.6 \%$ \\
\hline Particulates $(\mathrm{kg} / \mathrm{GWh})$ & 9,212 & $1 \%$ & 133 & $46 \%$ \\
\hline $\mathrm{GWP}\left(\mathrm{g} \mathrm{CO}_{2}\right.$-equiv/kWh) & 1,042 & $96 \%$ & 499 & $75 \%$ \\
\hline
\end{tabular}

Note: Three systems were studied in Spath and Mann, 1999: an average plant, an NSPS plant, and a lowemission boiler system (LEBS) plant. 


\subsection{Other Life Cycle Assessments on Power Production via Natural Gas Combined-Cycle}

Before beginning this LCA, a literature search was done to see what previous LCA-related studies had been conducted on NGCC systems. The following is a brief summary of pertinent publications.

\section{Rasheed (1997)}

A large portion of this document describes LCA and contains information about power plant technology. The remainder of the document focuses on greenhouse gas emissions of $\mathrm{CO}_{2}, \mathrm{NO}_{\mathrm{x}}$, and $\mathrm{CH}_{4}$ and the energy requirement for natural gas extraction and gathering, processing, transmission, and the NGCC power plant. The power plant does not incorporate any kind of $\mathrm{NO}_{\mathrm{x}}$ control, therefore the power plant $\mathrm{NO}_{\mathrm{x}}$ emissions are higher than our base case emissions. The report has some useful information but at times it was difficult to follow and interpret some of the tables. No other stressors such as resources, water emissions, or wastes were examined in this LCA.

\section{International Energy Agency Greenhouse Gas R\&D Programme (1999)}

This program studied greenhouse gas emissions for four different power generation options: pulverised coal boiler, natural gas fired combined-cycle, coal integrated gasification combined cycle, and $\mathrm{CO}_{2}$ recycle coal boiler (oxygen blown coal boiler with recycled $\mathrm{CO}_{2}$ for temperature control). The study examined the power plant emissions only. The website contains a 5-page summary of the NGCC system that they studied. Their turbine exhaust gas composition reveals that they assumed complete combustion of the natural gas feedstock and no sulfur emissions. Thus, the only air emissions from the power plant are $\mathrm{CO}_{2}$ and $\mathrm{NO}_{\mathrm{x}}$. This is one aspect that is different from NREL's study. This work is part of a more detailed report that is not readily accessible. Apparently, this report is quite old and more up-to-date information will be available in the future (Freund, 1999). Additionally, this study was done for the sole purpose of examining greenhouse gases, therefore, no additional stressors were included.

\section{Vattenfall (1996)}

This document outlines the LCA work that Vattenfall has done for the following electricity generation systems: hydro, nuclear, oil condensing, NGCC, gas turbine, wind, and biofueled combined heat and power. The assessments are cradle-to-grave, incorporating aspects such as construction, demolition, and transportation, but only a select number of stressors were examined. Eleven resources were inventoried in these LCAs, the water emissions were recorded as the total amount of nitrogen, and the waste was categorized into radioactive, demolition and other. The only air emissions examined were $\mathrm{NO}_{\mathrm{x}}, \mathrm{SO}_{2}, \mathrm{CO}$, dust, $\mathrm{HC}$, and $\mathrm{CO}_{2}$. It is not clear what is included in the $\mathrm{HC}$ category but since $\mathrm{CH}_{4}$ is one greenhouse gas that contributes to climate change it should probably be spelled out separately. The results of the life-cycle studies are being reviewed by Chalmers Contract Research Organization and the Swedish Environmental Research Institute. More recent publications regarding this work could not be found.

Waku et al. (1995)

Energy and $\mathrm{CO}_{2}$ emissions were examined in a cradle-to-grave LCA for liquefied NGCC and coal IGCC systems incorporating $\mathrm{CO}_{2}$ recovery and sequestration. This paper briefly summarizes these results which come from on going research activities sponsored by New Energy and Industrial Technology Development Organization. They define net energy ratio to be the total energy produced by the system divided by the total energy required for construction, operation, and maintenance of the system. This number does not include the energy in the natural gas or coal and therefore can only be compared to our external energy ratio. It appears that no other stressors have been examined but that their next step is to include inventories of air emissions such as $\mathrm{NO}_{\mathrm{x}}$ and $\mathrm{SO}_{\mathrm{x}}$. More recent publications regarding this work could not be found. 


\subsection{Summary of Results and Discussion}

Using natural gas to generate electricity, particularly in higher efficiency combined cycle power systems, can reduce the environmental impact of energy usage in this country. If NGCC systems were to replace the major form of power production in the U.S., coal-fired power plants, one would expect that the higher efficiency and cleaner burning nature of natural gas would result in fewer $\mathrm{SO}_{\mathrm{x}}$ and $\mathrm{NO}_{\mathrm{x}}$ emissions, less resource consumption, and less solid waste generation. However, to get a complete picture of the benefits of this technology versus the status quo, a cradle-to-grave examination is important because the environmental consequences depend not only on the power generation facility itself, but on the upstream processes as well. The base case power plant emissions for this system are lower than those required by NSPS under the CFR for gas-fired power plants (see Table 6). As indicated in Table 18, however, upstream $\mathrm{NO}_{\mathrm{x}}$ and $\mathrm{SO}_{\mathrm{x}}$ emissions are much larger than those from the power plant, while upstream particulate emissions are approximately equal to those emitted from the power plant. Without taking a life cycle approach to examining the environmental effects of this system, the total magnitude of these air emissions would have been severely underestimated.

Table 18: Comparison of $\mathrm{NO}_{x}, \mathrm{SO}_{\mathrm{x}}$, and Particulate Emission Levels

\begin{tabular}{|c|c|c|c|c|c|c|}
\hline & \multirow{2}{*}{$\begin{array}{c}\text { NSPS } \\
\text { limits } \\
(\mathrm{kg} / \mathrm{GWh})\end{array}$} & \multicolumn{5}{|c|}{ Base case } \\
\hline & & $\begin{array}{l}\text { Emissions } \\
\text { from power } \\
\text { plant } \\
(\mathrm{kg} / \mathrm{GWh})\end{array}$ & $\begin{array}{l}\% \text { of total } \\
\text { system } \\
\text { emissions from } \\
\text { power plant }\end{array}$ & $\begin{array}{c}\text { Emissions } \\
\text { from upstream } \\
\text { processes } \\
(\mathrm{kg} / \mathrm{GWh})\end{array}$ & $\begin{array}{l}\% \text { of total } \\
\text { system emissions } \\
\text { from upstream } \\
\text { processes }\end{array}$ & $\begin{array}{c}\text { Total } \\
\text { system } \\
\text { emissions } \\
(\mathrm{kg} / \mathrm{GWh})\end{array}$ \\
\hline $\mathrm{NO}_{\mathrm{x}}$ & 634 & 95 & $17 \%$ & 475 & $83 \%$ & 570 \\
\hline $\mathrm{SO}_{\mathrm{x}}$ & 634 & 2 & $1 \%$ & 322 & $99 \%$ & 324 \\
\hline Particulates & 95 & 62 & $46 \%$ & 71 & $54 \%$ & 133 \\
\hline
\end{tabular}

Of all air emissions, $\mathrm{CO}_{2}$ is released at the highest rate $(440 \mathrm{~g} / \mathrm{kWh})$. The $\mathrm{GWP}$, a weighted combination of $\mathrm{CO}_{2}, \mathrm{CH}_{4}$, and $\mathrm{N}_{2} \mathrm{O}$, is $499 \mathrm{~g} \mathrm{CO}_{2}$-equivalent $/ \mathrm{kWh} . \mathrm{CO}_{2}$ is therefore responsible for $88 \%$ of the system GWP, with the $\mathrm{CO}_{2}$ from the power plant representing $75 \%$ of this GWP. Although $\mathrm{CO}_{2}$ emissions are 65 times those of $\mathrm{CH}_{4}$, the higher radiative forcing of $\mathrm{CH}_{4}$ causes it to be responsible for $12 \%$ of the GWP. Natural gas losses during gas production and distribution account for $25 \%$ of the total greenhouse gases emitted by the system. The following figures present more detail on relative amounts and sources of greenhouse gases.

Breakdown of GWP Emissions (g CO -equivalent/kWh)

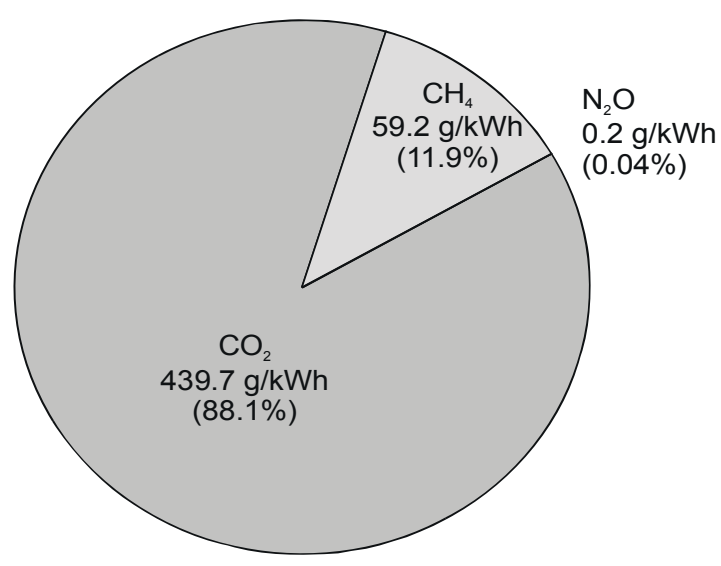

Breakdown of Process Step Contributions to GWP $\left(\mathrm{CO}_{2}\right.$-equivalence, including $\mathrm{CO}_{2}, \mathrm{CH}_{4}$, and $\left.\mathrm{N}_{2} \mathrm{O}\right)$

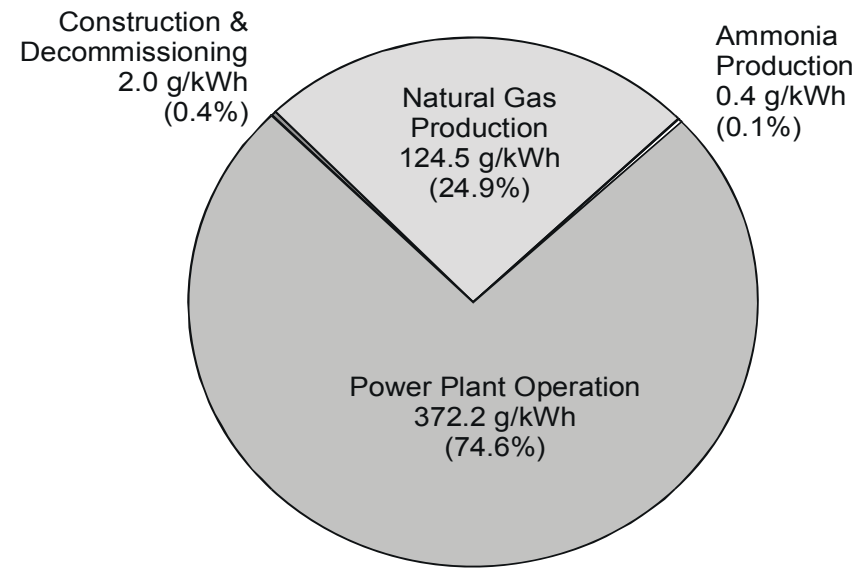


Similar to the findings of previous NREL LCAs, the total amount of water pollutants was small compared to other emissions. Additionally, because the only waste stream from the power plant itself is spent catalyst from the SCR unit, there is not a large amount of waste generated by the system as a whole. Although the majority of the natural gas pipeline compressors are driven by reciprocating engines and turbines which are fueled by the natural gas, there are some electrical machines and electrical requirements at the compressor stations. Ironically, the majority of the system waste $(65 \%)$ is from coal-fired power plants that generate this needed electricity, where coal represents $51.7 \%$ of the U.S. average grid mix.

Although the power plant efficiency of the NGCC system is high $(48.8 \%$, HHV), the external energy efficiency $(29.2 \%, \mathrm{LHV})$ and the external energy ratio (2.2, LHV) show that energy consumption from upstream processes, including natural gas production and distribution, is significant. Natural gas production and distribution accounts for $98 \%$ of the non-feedstock energy consumed by the system. Most of the energy consumption is a result of the energy requirements for extracting and transporting the natural gas. Diesel oil is combusted to supply electricity to the drilling equipment, and pipeline transport uses a combination of grid electricity and natural gas to move the natural gas from its point of origin to its destination. The energy results also show that for every MJ of fossil energy consumed by the system, $0.4 \mathrm{MJ}$ of electricity produced.

The sensitivity analysis performed for this LCA shows that there are only two significant opportunities to lessen the environmental impacts of NGCC systems: increasing system efficiency and reducing natural gas losses. Increasing system efficiency would decrease the overall environmental impact of this system per $\mathrm{kWh}$ of electricity produced. However, it should be noted that NGCC is currently the most efficient and lowest energy-intensive technology available for large-scale electricity production. Mitigating natural gas losses during production and distribution increases the net energy balance and lowers the GWP.

This LCA examined the full chain of operations that must occur for a NGCC to produce electricity. These operations include the extraction, refining, and distribution of natural gas, construction of the pipeline and power plant, ammonia production and distribution, and upstream grid energy production. The emissions, energy consumption, and resource use associated with all of these operations were summed to provide a more accurate picture of the environmental impacts than can be understood from studying only the power plant. Overall, the number of environmental stressors from this system is few, and far less than those that result from today's coal-fired boilers. This, combined with the fact that these systems have high efficiencies, using NGCC to displace current coal-fired boilers is a sound method for reducing the environmental burden of power production. 


\subsection{References}

American Coal Ash Association. (1996). Annual Coal Combustion Product (CCP) Survey Report. 1996 Coal Combustion Product (CCP)- Production and Use (Short Tons). 2760 Eisenhower Avenue, Suite 304, Alexandria, VA 22314-4553.

DynCorp EENSP, Inc. (1995). Assessment of the Environmental Benefits of Renewables Deployment: A Total Fuel Cycle Analysis of the Greenhouse Gas Impacts of Renewable Generation Technologies in Regional Utility Systems. Prepared for the National Renewable Energy Laboratory, contract no. DEAC02-83CH10093, May.

Environmental Catalyst Consultants, Inc. (1992). Status of Selective Catalytic Reduction for $\mathrm{NO}_{\mathrm{x}}$ Control in Electric Power Generation Applications.

Harrison, M.R.; Shires, T.M.; Wessels, J.K.; Cowgill, R.M. (1997). "Methane Emissions from the Natural Gas Industry." Project Summary. United States Environmental Protection Agency. Report \# 600/SR96/080. National Risk Management Research Laboratory. Research Triangle Park, NC.

Houghton, J.T.; Meira Filho, L.G.; Callander, B.A.; Harris, N.; Kattenberg, A.; Maskell, K., eds. (1996). Climate Change 1995. The Science of Climate Change. Published for the Intergovernmental Panel on Climate Change. New York: Cambridge University Press.

IEA Greenhouse Gas Programme. (1999). "Greenhouse Gas Emissions from Power Stations." Stoke Orchard, Cheltenham, Glos. GL52 4RZ, United Kingdom. Paul Freund - Project Director. Website: www.ieagreen.org.uk.

International Energy Agency, Organization for Economic Co-operation and Development (IEA/OECD). (1991). Greenhouse Gas Emissions: The Energy Dimension. Paris, France: OECD.

Kirchgessner, D.A.; Lott, R.A.; Cowgill, R.M.; Harrison, M.R.; Shires, T.M. (1997) "Estimate of Methane Emissions from the U.S. Natural Gas Industry.” Chemosphere. Vol. 35, No. 6; pp. 1365-1390.

Kirk-Othmer's Encyclopedia of Chemical Technology. (1993). 4th Edition, Vol. 12, pp. 324-335.

Lacson, J.G. (1999). CEH Product Review: Natural Gas. Chemical Economics Handbook. SRI International. Menlo Park, CA. Volume 4. Section 229.2000.

Makansi, J. (September 1988). "Reducing $\mathrm{NO}_{\mathrm{x}}$ Emissions: Boilers, Gas Turbines, Engines” Special Report, Power.

Mann, M.K.; Spath, P.L. (1997). Life Cycle Assessment of a Biomass Gasification Combined-Cycle Power System. National Renewable Energy Laboratory, Golden, CO, TP-430-23076.

Mann, M.K.; Spath, P.L. (2000). Life Cycle Assessment of Biomass Cofiring in a Coal-fired Power Plant. National Renewable Energy Laboratory, Golden, CO, TP-430-26963.

Oegema, Rick. (1999). Personal Correspondence. ABB Group. Knoxville, TN. 
Office of the Federal Register National Archives and Records Administration. (July 1996) Code of Federal Regulations. Protection of Environment. Title 40. Part 60.

Rasheed, S.T. (1997). "Net-Energy Life-Cycle Analysis of a Natural Gas Combined-Cycle Power Ensemble.” University of Oklahoma. Graduate Thesis. Master of Science Mechanical Engineering.

Resch, R.A. (1995). "EPA's Natural Gas Star Program.” Society of Petroleum Engineers Conference. Paper No. SPE 29731. Houston, TX, March 27-29.

Schultz, S.C., Kitto, J.B. (1992). STEAM Its Generation and Use. Babcock \& Wilcox, Barberton, OH.

SETAC. (1997, 1998). Life-Cycle Impact Assessment: The State-of-the-Art. Society of Environmental Toxicology and Chemistry. Pensacola, FL.

Spath, P.L; Mann, M.K. (1999). Life Cycle Assessment of Coal-fired Power Production. National Renewable Energy Laboratory, Golden, CO, TP-570-25119.

Spath, P.L; Mann, M.K. (2000). Life Cycle Assessment of a Direct-fired Biomass Power Generation System. National Renewable Energy Laboratory, Golden, CO, TP-570-26942.

SRI International. (1989). $N O_{x}$ Removal. Process Economic Program. Report No. 200. Menlo Park, CA.

Ullmann's Encyclopedia of Industrial Chemistry. (1986). 4th Edition, Vol. A17, pp. 74-101, Weinheim (Federal Replublic of Germany): VCH.

U.S. Department of Energy. (December 1998). Annual Energy Outlook 1999. Energy Information Administration, Office of Energy Markets and End Use. DOE/EIA-0383(99). Washington, D.C.

U.S. Department of Energy. (July 1998). Annual Energy Review 1997. Energy Information Administration, Office of Energy Markets and End Use. DOE/EIA-0384(97). Washington, D.C.

U.S. Environmental Protection Agency. (1995). Compilation of Air Pollutant Emission Factors. United States Environmental Protection Agency. AP-42. Vol. 1, parts 1, 2, and 3; Stationary Point and Area Sources. Ann Arbor, MI.

Utility Data Institute (1999). World Electric Power Plants Database - All Units, November Edition, Washington, D.C.: McGraw-Hill Energy.

Wiltsee, G. (1998). Urban Wood Waste Resource Assessment. NREL/SR-570-25918. Golden, CO: National Renewable Energy Laboratory. Work performed by Appel Consultants, Inc., Valencia, CA. 
Appendix - Sensitivity Results Tables 
SENSITIVITY ANALYSIS RESULTS: GWP

\begin{tabular}{|c|c|c|c|c|c|c|c|c|c|c|}
\hline & Base case & cap_factor_75 & cap_factor_90 & cap_factor_95 & efficiency_high & efficiency_low & ng_loss_low & ng_loss_high & pipeline_high & pipeline_low \\
\hline $\mathrm{CO} 2$ & 439.69 & 439.82 & 439.47 & 439.37 & 398.82 & 489.90 & 439.07 & 441.54 & 439.97 & 439.41 \\
\hline $\mathrm{CH} 4$ & 59.24 & 59.24 & 59.24 & 59.24 & 53.73 & 66.00 & 30.64 & 144.85 & 59.24 & 59.24 \\
\hline $\mathrm{N} 2 \mathrm{O}$ & 0.22 & 0.23 & 0.22 & 0.22 & 0.20 & 0.25 & 0.22 & 0.23 & 0.23 & 0.22 \\
\hline \multicolumn{11}{|c|}{$\begin{array}{l}\% \text { diff from } \\
\text { base case }\end{array}$} \\
\hline $\mathrm{CO} 2$ & $\mathrm{~N} / \mathrm{A}$ & $0.0 \%$ & $-0.1 \%$ & $-0.1 \%$ & $-9.3 \%$ & $11.4 \%$ & $-0.1 \%$ & $0.4 \%$ & $0.1 \%$ & $-0.1 \%$ \\
\hline $\mathrm{CH} 4$ & $\mathrm{~N} / \mathrm{A}$ & $0.0 \%$ & $0.0 \%$ & $0.0 \%$ & $-9.3 \%$ & $11.4 \%$ & $-48.3 \%$ & $144.5 \%$ & $0.0 \%$ & $0.0 \%$ \\
\hline $\mathrm{N} 2 \mathrm{O}$ & $\mathrm{N} / \mathrm{A}$ & $1.3 \%$ & $-2.2 \%$ & $-3.1 \%$ & $-9.3 \%$ & $11.4 \%$ & $-0.7 \%$ & $2.2 \%$ & $3.0 \%$ & $-3.0 \%$ \\
\hline GWP & $\mathrm{N} / \mathrm{A}$ & $0.0 \%$ & $0.0 \%$ & $-0.1 \%$ & $-9.3 \%$ & $11.4 \%$ & $-5.9 \%$ & $17.5 \%$ & $0.1 \%$ & $-0.1 \%$ \\
\hline
\end{tabular}

\section{SENSITIVITY ANALYSIS RESULTS: GWP (continued)}

\begin{tabular}{|c|c|c|c|c|c|c|c|}
\hline & Base case & NOx_Case1 & NOx_Case2 & NOx_Case3 & NOx_Case4 & NOx_Case5 & NOx_Case6 \\
\hline $\mathrm{CO} 2$ & 439.69 & $4 \overline{37.92}$ & 439.77 & $4 \overline{37.92}$ & $4 \overline{39.94}$ & 440.71 & $4 \overline{37.92}$ \\
\hline $\mathrm{CH} 4$ & 59.24 & 59.22 & 59.24 & 59.22 & 59.24 & 59.27 & 59.22 \\
\hline $\mathrm{N} 2 \mathrm{O}$ & 0.22 & 0.22 & 0.22 & 0.22 & 0.22 & 0.23 & 0.22 \\
\hline GWP & 499.15 & 497.36 & 499.23 & 497.36 & 499.41 & 500.21 & 497.36 \\
\hline \multicolumn{8}{|c|}{$\begin{array}{l}\% \text { diff from } \\
\text { base case }\end{array}$} \\
\hline $\mathrm{CO} 2$ & $\mathrm{~N} / \mathrm{A}$ & $-0.4 \%$ & $0.0 \%$ & $-0.4 \%$ & $0.1 \%$ & $0.2 \%$ & $-0.4 \%$ \\
\hline $\mathrm{CH} 4$ & $\mathrm{~N} / \mathrm{A}$ & $0.0 \%$ & $0.0 \%$ & $0.0 \%$ & $0.0 \%$ & $0.1 \%$ & $0.0 \%$ \\
\hline $\mathrm{N} 2 \mathrm{O}$ & $\mathrm{N} / \mathrm{A}$ & $-0.5 \%$ & $0.1 \%$ & $-0.5 \%$ & $0.3 \%$ & $1.1 \%$ & $-0.5 \%$ \\
\hline GWP & $\mathrm{N} / \mathrm{A}$ & $-0.4 \%$ & $0.0 \%$ & $-0.4 \%$ & $0.1 \%$ & $0.2 \%$ & $-0.4 \%$ \\
\hline
\end{tabular}


SENSITIVITY ANALYSIS RESULTS: ENERGY BALANCE

\begin{tabular}{|c|c|c|c|c|c|c|c|c|c|c|}
\hline & Base case & cap_factor 75 & cap_factor 90 & cap factor 95 & efficiency_high & efficiency_low & ng_loss_low & ng_loss_high & pipeline_high & pipeline_low \\
\hline Life cycle efficiency & $-70.1 \%$ & $-70.1 \%$ & $-70.0 \%$ & $-70.0 \%$ & $-64.5 \%$ & $-75.6 \%$ & $-69.8 \%$ & $-70.8 \%$ & $-70.1 \%$ & $-70.0 \%$ \\
\hline External energy efficiency & $29.9 \%$ & $29.9 \%$ & $30.0 \%$ & $30.0 \%$ & $35.5 \%$ & $24.4 \%$ & $30.2 \%$ & $29.2 \%$ & $29.9 \%$ & $30.0 \%$ \\
\hline Net energy ratio & 0.44 & 0.44 & 0.44 & 0.44 & 0.48 & 0.39 & 0.44 & 0.43 & 0.44 & 0.44 \\
\hline External energy ratio & 2.24 & 2.24 & 2.24 & 2.24 & 2.47 & 2.01 & 2.26 & 2.17 & 2.23 & 2.24 \\
\hline \multicolumn{11}{|l|}{$\%$ diff from base case } \\
\hline Life cycle efficiency & $\mathrm{N} / \mathrm{A}$ & $0.0 \%$ & $0.1 \%$ & $0.1 \%$ & $7.9 \%$ & $-7.9 \%$ & $0.4 \%$ & $-1.1 \%$ & $-0.1 \%$ & $0.1 \%$ \\
\hline External energy efficiency & $\bar{N} / \mathrm{A}$ & $-0.1 \%$ & $0.2 \%$ & $0.2 \%$ & $18.5 \%$ & $-18.5 \%$ & $0.8 \%$ & $-2.5 \%$ & $-0.2 \%$ & $0.2 \%$ \\
\hline Net energy ratio & $\mathrm{N} / \mathrm{A}$ & $0.0 \%$ & $0.0 \%$ & $0.0 \%$ & $10.2 \%$ & $-10.2 \%$ & $0.2 \%$ & $-0.6 \%$ & $0.0 \%$ & $0.0 \%$ \\
\hline External energy ratio & $\mathrm{N} / \mathrm{A}$ & $-0.1 \%$ & $0.2 \%$ & $0.2 \%$ & $10.2 \%$ & $-10.2 \%$ & $1.0 \%$ & $-3.0 \%$ & $-0.2 \%$ & $0.2 \%$ \\
\hline \multicolumn{11}{|l|}{$\begin{array}{c}\text { percentage point change } \\
\text { from base case }\end{array}$} \\
\hline Life cycle efficiency & $\mathrm{N} / \mathrm{A}$ & 0.00 & 0.00 & 0.00 & 0.06 & -0.06 & 0.00 & -0.01 & 0.00 & 0.00 \\
\hline External energy efficiency & $\mathrm{N} / \mathrm{A}$ & 0.00 & 0.00 & 0.00 & 0.06 & -0.06 & 0.00 & -0.01 & 0.00 & 0.00 \\
\hline
\end{tabular}

\section{SENSITIVITY ANALYSIS RESULTS: ENERGY BALANCE (continued'}

\begin{tabular}{|c|c|c|c|c|c|c|c|}
\hline & Base case & NOx_Case1 & NOx_Case2 & NOx_Case3 & NOx_Case4 & NOx_Case5 & NOx_Case6 \\
\hline Life cycle efficiency & $-70.1 \%$ & $-69.9 \%$ & $-70.1 \%$ & $-69.9 \%$ & $-70.2 \%$ & $-70.4 \%$ & $-69.9 \%$ \\
\hline External energy efficiency & $29.9 \%$ & $30.1 \%$ & $29.9 \%$ & $30.1 \%$ & $29.8 \%$ & $29.6 \%$ & $30.1 \%$ \\
\hline Net energy ratio & 0.44 & 0.44 & 0.44 & 0.44 & 0.44 & 0.43 & 0.44 \\
\hline External energy ratio & 2.24 & 2.25 & 2.24 & 2.25 & 2.23 & 2.21 & 2.25 \\
\hline \multicolumn{8}{|l|}{$\%$ diff from base case } \\
\hline Life cycle efficiency & $\mathrm{N} / \mathrm{A}$ & $0.2 \%$ & $0.0 \%$ & $0.2 \%$ & $-0.1 \%$ & $-0.5 \%$ & $0.2 \%$ \\
\hline External energy efficiency & $\mathrm{N} / \mathrm{A}$ & $0.5 \%$ & $-0.1 \%$ & $0.5 \%$ & $-0.3 \%$ & $-1.1 \%$ & $0.5 \%$ \\
\hline Net energy ratio & $\mathrm{N} / \mathrm{A}$ & $0.1 \%$ & $0.0 \%$ & $0.1 \%$ & $-0.1 \%$ & $-0.3 \%$ & $0.1 \%$ \\
\hline External energy ratio & $\mathrm{N} / \mathrm{A}$ & $0.6 \%$ & $-0.1 \%$ & $0.6 \%$ & $-0.3 \%$ & $-1.3 \%$ & $0.6 \%$ \\
\hline \multicolumn{8}{|l|}{$\begin{array}{c}\text { percentage point change } \\
\text { from base case }\end{array}$} \\
\hline Life cycle efficiency & $\mathrm{N} / \mathrm{A}$ & 0.00 & 0.00 & 0.00 & 0.00 & 0.00 & 0.00 \\
\hline External energy efficiency & $\mathrm{N} / \mathrm{A}$ & 0.00 & 0.00 & 0.00 & 0.00 & 0.00 & 0.00 \\
\hline
\end{tabular}


SENSITIVITY ANALYSIS RESULTS: AIR EMISSIONS

$\%$ of Total in $\%$ of Total from $\%$ of Total from $\%$ of Total from $\%$ of Total from Total \% of Total this of Toble except Constuction \& $\begin{array}{llllll}\text { Total } & \% \text { of Total this table except } & \text { Construction \& } & \text { Natural Gas } & \text { Ammonia } & \text { Electricity } \\ \text { in } / \mathrm{kWh}) & \text { in this table } \quad \mathrm{CO} 2 & \text { Decommisioning } & \text { Production } & \text { Production } & \text { Generation }\end{array}$

$\%$ change

\section{Base cas}

$2.10 \mathrm{E}-02$
$6.32 \mathrm{E}-02$

(a) Benzene

6.32E-02

$4.40 \mathrm{E}+02$

$0.00 \%$

$0.01 \%$

$98.91 \%$

a) Carbon Monoxide (CO)

$2.87 \mathrm{E}-01 \quad 0.06 \%$

$0.43 \%$

(a) Non-methane Hydrocarbons (NMHCs) $6.28 \mathrm{E}-01$

(a) Hydrogen Sulfide (H2S)

$1.41 \mathrm{E}-08$

(a) Methane $(\mathrm{CH} 4)$

$0.00 \%$
$0.63 \%$

(a) Formaldehyde $(\mathrm{CH} 2 \mathrm{O})$

$2.82 \mathrm{E}+00$

$8.57 \mathrm{E}-03$

5.70E-01

$0.63 \%$

$0.13 \%$

(a) Nitrous Oxide (N2O)

(a) Particulates (unspecified)

7.19E-04

$0.00 \%$

(a) Sulfur Oxides (SOx as SO2)

1.33E-01

$0.03 \%$

$0.07 \%$

$1.30 \%$

$5.91 \%$

$12.94 \%$

$0.00 \%$

$58.08 \%$

$0.18 \%$

$11.75 \%$

$0.01 \%$

$2.73 \%$

$6.67 \%$

$0.19 \%$
$0.00 \%$
$0.46 \%$
$1.59 \%$
$2.32 \%$
$100.00 \%$
$0.01 \%$
$0.00 \%$
$1.64 \%$
$19.35 \%$
$38.00 \%$
$15.44 \%$

$0.00 \%$
$99.90 \%$
$15.01 \%$
$88.57 \%$
$95.84 \%$
$0.00 \%$
$98.39 \%$
$0.00 \%$
$81.54 \%$
$80.20 \%$
$15.57 \%$
$83.82 \%$

$1.60 \%$

$0.10 \%$

$0.10 \%$

$0.55 \%$

$0.23 \%$

$0.00 \%$

$0.02 \%$

$0.00 \%$

$0.14 \%$

$0.45 \%$

$0.04 \%$

$0.16 \%$

$\begin{array}{rr}98.21 \% & \text { N/A } \\ 0.00 \% & \text { N/A } \\ 84.43 \% & \text { N/A } \\ 9.29 \% & \text { N/A } \\ 1.62 \% & \text { N/A } \\ 0.00 \% & \text { N/A } \\ 1.57 \% & \text { N/A } \\ 100.00 \% & \text { N/A } \\ 16.68 \% & \text { N/A } \\ 0.00 \% & \text { N/A } \\ 46.39 \% & \text { N/A } \\ 0.59 \% & \text { N/A }\end{array}$

\section{cap_factor_75}

(a) Ammonia (NH3)

(a) Benzene (C6H6)

(a) Carbon Dioxide (CO2)

2.10E-02

$6.32 \mathrm{E}-02$

$4.40 \mathrm{E}+02$

2.87E-01

(a) Carbon Monoxide (CO)

$0.00 \%$

$0.01 \%$

$98.91 \%$

(a) Non-methane Hydrocarbons (NMHCs)

(a) Hydrogen Sulfide (H2S)

$6.29 \mathrm{E}-01$

(a) Methane $(\mathrm{CH} 4)$

$1.50 \mathrm{E}-08$

$0.06 \%$

$0.14 \%$
$0.00 \%$

$0.00 \%$
$0.63 \%$

$0.00 \%$

(a) Formaldehyde $(\mathrm{CH} 2 \mathrm{O})$

$8.57 \mathrm{E}-03$

$5.71 \mathrm{E}-01$

$0.13 \%$

(a) Nitrogen Oxides (NOx as NO2)

(a) Nitrous Oxide (N2O)

(a) Particulates (unspecified)

(a) Sulfur Oxides ( $\mathrm{SOx}$ as $\mathrm{SO} 2$ )

7.28E-04

1.36E-01

$0.00 \%$

$0.03 \%$

$0.07 \%$

$0.43 \%$

$1.30 \%$

$5.90 \%$

$12.94 \%$

$0.00 \%$

$57.98 \%$

$0.18 \%$

$11.74 \%$

$0.01 \%$

$2.80 \%$

$6.73 \%$

$0.20 \%$
$0.00 \%$
$0.49 \%$
$1.69 \%$
$2.47 \%$
$100.00 \%$
$0.01 \%$
$0.00 \%$
$1.74 \%$
$20.38 \%$
$39.53 \%$
$16.30 \%$

$0.00 \%$

$99.90 \%$

$15.01 \%$

$88.48 \%$

$95.69 \%$

$0.00 \%$

$98.39 \%$

$0.00 \%$

$81.45 \%$

$79.17 \%$

$15.19 \%$

$82.97 \%$

$1.60 \%$

$0.10 \%$

$0.10 \%$

$0.55 \%$

$0.23 \%$

$0.00 \%$

$0.02 \%$

$0.00 \%$

$0.14 \%$

$0.45 \%$

$0.03 \%$

$0.15 \%$

$98.20 \%$

$0.00 \%$

$84.41 \%$

$9.28 \%$

$1.61 \%$

$0.00 \%$

$1.57 \%$

$100.00 \%$

$16.67 \%$

$0.00 \%$

$45.25 \%$

$0.58 \%$

$0.01 \%$

$0.00 \%$

$0.03 \%$

$0.11 \%$

$0.15 \%$

$0.00 \%$

$0.00 \%$

$0.11 \%$

$1.29 \%$

$2.53 \%$

$1.03 \%$

\section{cap_factor_90}

(a) Ammonia (NH3)

(a) Benzene (C6H6)

(a) Carbon Dioxide (CO2)

$0.00 \%$

$0.43 \%$

$6.32 \mathrm{E}-02 \quad 0.01 \%$

$4.39 \mathrm{E}+02 \quad 98.91 \%$

(a) Carbon Monoxide (CO)

$2.86 \mathrm{E}-01$

$0.06 \%$

$0.14 \%$

$0.00 \%$

(a) Hydrogen Sulfide (H2S)

(a) Methane $(\mathrm{CH} 4$

$1.25 \mathrm{E}-08$

$2.82 \mathrm{E}+00$

$0.63 \%$

(a) Formaldehyde ( $\mathrm{CH} 2 \mathrm{O})$

(a) Nitrogen Oxides (NOx as NO2)

(a) Nitrous Oxide (N2O)

$8.57 \mathrm{E}-03 \quad 0.00 \%$

$5.69 \mathrm{E}-01 \quad 0.13 \%$

7.03E-04 $0.00 \%$

(a) Particulates (unspecified)

$1.27 \mathrm{E}-0$

$0.03 \%$

$1.31 \%$

$0.17 \%$

$0.00 \%$

$0.00 \%$

$99.90 \%$

$5.91 \%$

$12.95 \%$

$0.00 \%$

$58.25 \%$

$0.18 \%$

$11.76 \%$

$0.01 \%$

$2.62 \%$

$6.58 \%$

$0.41 \% \quad 15.02 \%$

$1.42 \% \quad 88.73 \%$

$2.06 \% \quad 96.09 \%$

$100.00 \% \quad 0.00 \%$

$98.39 \%$

$\begin{array}{lr}0.01 \% & 0.00 \% \\ 1.46 \% & 81.69 \%\end{array}$

$1.46 \% \quad 81.69 \%$

$17.58 \% \quad 81.96 \%$

$35.26 \% \quad 16.26 \%$

$13.96 \% \quad 85.28 \%$

$1.60 \%$
$0.10 \%$
$0.10 \%$
$0.55 \%$
$0.23 \%$
$0.00 \%$
$0.02 \%$
$0.00 \%$
$0.14 \%$
$0.46 \%$
$0.04 \%$
$0.16 \%$

$98.23 \%$

$-0.02 \%$

$0.00 \%$

$84.48 \%-\quad-0.05 \%$

$9.31 \% \quad-0.18 \%$

$1.62 \%-0.26 \%$

$0.00 \% \quad-11.11 \%$

$1.57 \% \quad 0.00 \%$

$100.00 \% \quad 0.00 \%$

$16.71 \% \quad-0.18 \%$

$0.00 \% \quad-2.15 \%$

$48.44 \%--4.22 \%$

$0.16 \% \quad 0.60 \% \quad-1.72 \%$

$0.07 \%$


SENSITIVITY ANALYSIS RESULTS: AIR EMISSIONS (continued)

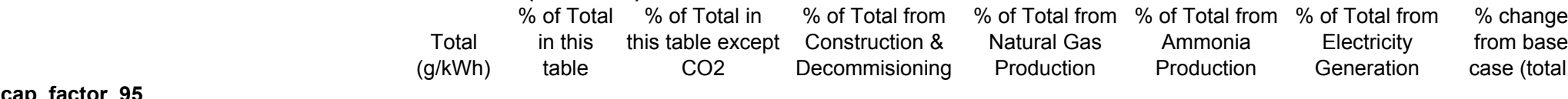

(g/kWh) table

(a) Ammonia $(\mathrm{NH} 3)$

$0.00 \%$

(a) Carbon Dioxide (CO2)

$6.32 \mathrm{E}-02$

4.39E+02

$0.01 \%$

(a) Carbon Monoxide (CO)

2.86E-01 $\quad 0.06 \%$

$0.43 \%$

$1.31 \%$

$0.16 \%$

(a) Non-methane Hydrocarbons (NMHCs) $6.26 \mathrm{E}-01$

$0.06 \%$

$5.92 \%$

$1.18 \mathrm{E}-08$

(a) Hydrogen Sulfide (H2S)

$0.00 \%$

(a) Methane $(\mathrm{CH} 4)$

$2.82 \mathrm{E}+00 \quad 0.63 \%$

(a) Formaldehyde $(\mathrm{CH} 2 \mathrm{O})$

$8.57 \mathrm{E}-03 \quad 0.00 \%$

(a) Nitrogen Oxides (NOx as NO2)

$5.69 \mathrm{E}-01$

$0.13 \%$

(a) Nitrous Oxide (N2O)

(a) Particulates (unspecified)

$6.97 \mathrm{E}-04 \quad 0.00 \%$

(a) Sulfur Oxides (SOx as SO2)

$1.25 \mathrm{E}-01 \quad 0.03 \%$

$12.95 \%$

$0.00 \%$

$58.32 \%$

$0.18 \%$

$11.76 \%$

$0.01 \%$

$2.58 \%$

$0.07 \%$

$6.54 \%$

$0.38 \%$

$1.34 \%$

$1.96 \%$

$100.00 \%$

$0.01 \%$

$0.00 \%$
$1.38 \%$

$1.38 \%$

$34.04 \%$

$13.32 \%$

\author{
$0.00 \%$
}

$99.90 \%$

$15.02 \%$

$88.80 \%$

$96.19 \%$

$0.00 \%$

$98.39 \%$

$81.75 \%$

$82.72 \%$

$16.57 \%$

$85.91 \%$

$1.60 \%$

$0.10 \%$
$0.10 \%$

$0.55 \%$

$0.23 \%$

$0.00 \%$

$0.02 \%$

$0.00 \%$

$0.14 \%$

$0.47 \%$

$0.04 \%$

$0.16 \%$

$98.24 \%$

$0.00 \%$

$84.49 \%$

$9.31 \%$

$1.62 \%$

$0.00 \%$

$1.57 \%$

$100.00 \%$

$16.73 \%$

$0.00 \%$

$49.36 \%$

$0.60 \%$

$-0.03 \%$

$0.00 \%$

$-0.25 \%$

$-0.37 \%$

$-15.79 \%$

$-15.79 \%$
$0.00 \%$

$0.00 \%$

$-0.26 \%$

$-3.06 \%$

$-6.00 \%$

\title{
efficiency_high
}

(a) Ammonia (NH3)

(a) Benzene (C6H6)

(a) Carbon Dioxide (CO2)

1.90E-02

$0.00 \%$

$0.43 \%$

a) Carbon Monoxide (CO)

$\begin{array}{rr}5.74 \mathrm{E}-02 & 0.01 \% \\ 3.99 \mathrm{E}+02 & 98.91 \%\end{array}$

$98.91 \%$

(a) Non-methane Hydrocarbons (NMHCs)

$60 \mathrm{E}-01$

(a) Hydrogen Sulfide (H2S)

$5.70 \mathrm{E}-0$

(a) Methane $(\mathrm{CH} 4)$

$0.14 \%$
$0.00 \%$

$0.63 \%$

(a) Formaldehyde $(\mathrm{CH} 2 \mathrm{O})$

7.77E-03 $\quad 0.00 \%$

$5.17 \mathrm{E}-01 \quad 0.13 \%$

(a) Nitrogen Oxides (NOx as NO2)

6.52E-04

$0.00 \%$

(a) Particulates (unspecified)

$1.20 \mathrm{E}-01 \quad 0.03 \%$

(a) Sulfur Oxides (SOx as SO2)

2.94E-01

$0.07 \%$

$1.30 \%$

$0.00 \%$

$99.90 \%$

$5.91 \%$

$12.94 \%$

$0.00 \%$

$58.08 \%$

$0.18 \%$

$11.75 \%$

$0.01 \%$

$2.73 \%$

$6.67 \%$

$0.00 \%$

$15.01 \%$

$88.57 \%$

$1.59 \%$

$2.32 \%$

$100.00 \%$

$0.01 \%$

$0.00 \%$

$1.64 \%$

$19.35 \%$

$38.00 \%$

$15.44 \%$

$95.84 \%$

$0.00 \%$

$98.39 \%$

$0.00 \%$

$81.54 \%$

$80.20 \%$

$15.57 \%$

$83.82 \%$

$1.60 \%$

$98.21 \%$

$0.00 \%$

$84.43 \%$

$0.10 \%$

$0.55 \%$

$0.23 \%$

$0.00 \%$

$0.02 \%$

$0.00 \%$

$0.14 \%$

$0.45 \%$

$0.04 \%$

$0.16 \%$

$9.29 \%$

$1.62 \%$

$0.00 \%$

$1.57 \%$

$100.00 \%$

$16.68 \%$

$0.00 \%$

$46.39 \%$

$0.59 \%$

$-9.30 \%$

$-9.30 \%$

$-9.30 \%$

$-9.30 \%$

$-9.30 \%$

$-9.30 \%$

$-9.30 \%$

$-9.30 \%$

$-9.30 \%$

$-9.30 \%$

\section{efficiency_low}

(a) Ammonia (NH3)

(a) Benzene (C6H6)

2.34E-02

$0.00 \%$

$0.43 \%$

(a) Carbon Dioxide (CO2)

$7.05 \mathrm{E}-02$

4.90E+02 $\quad 98.91 \%$

(a) Carbon Monoxide (CO)

3.20E-01

$0.06 \%$
$0.14 \%$

$0.00 \%$

(a) Hydrogen Sulfide (H2S)

$1.57 \mathrm{E}-08$

(a) Methane $(\mathrm{CH} 4)$

$3.14 \mathrm{E}+00 \quad 0.63 \%$

$\begin{array}{ll}9.54 \mathrm{E}-03 & 0.00 \% \\ 6.36 \mathrm{E}-01 & 0.13 \%\end{array}$

(a) Formaldehyde $(\mathrm{CH} 2 \mathrm{O})$

(a) Nitrogen Oxides (NOx as NO2)

(a) Nitrous Oxide (N2O)

$8.01 \mathrm{E}-04 \quad 0.00 \%$

(a) Particulates (unspecified)

$1.48 \mathrm{E}-01 \quad 0.03 \%$

$1.30 \%$

$0.19 \%$

$0.00 \%$

$0.00 \%$

$99.90 \%$

$15.01 \%$

$5.91 \%$

$12.94 \%$

$0.00 \%$

$58.08 \%$

$0.18 \%$

$11.75 \%$

$0.01 \%$

$2.73 \%$

$6.67 \%$

$1.59 \%$

$2.32 \%$

$100.00 \%$

$0.01 \%$

$0.00 \%$

$1.64 \%$

$19.35 \%$

$38.00 \%$

$15.44 \%$

$95.84 \%$

$0.00 \%$

$98.39 \%$

$0.00 \%$

$81.54 \%$

$80.20 \%$

$1.60 \%$

$98.21 \%$

$11.42 \%$

$0.10 \% \quad 0.00 \%$

$84.43 \%$

$9.29 \%$

$1.62 \%$

$0.00 \%$

$1.57 \%$

$\begin{array}{rr}0.00 \% & 100.00 \% \\ 0.14 \% & 16.68 \%\end{array}$

$0.14 \%$

$0.45 \%$

$0.04 \%$

$0.00 \%$

$46.39 \%$

$0.59 \%$

$11.42 \%$

$11.42 \%$

$11.42 \%$

$11.42 \%$

$11.42 \%$

$11.42 \%$

$11.42 \%$

$11.42 \%$

$11.42 \%$ 
SENSITIVITY ANALYSIS RESULTS: AIR EMISSIONS (continued)

$\%$ of Total in Total $\%$ of Total this

$(\mathrm{g} / \mathrm{kWh})$ in this table CO2

$\%$ of Total from Construction \& $\%$ of Total from $\%$ Natural Gas $\%$ of Total from Ammonia Production

of Total from Electricity

$\%$ change

ng_loss_low

(a) Ammonia (NH3)

(a) Benzene (C6H6)

$2.10 \mathrm{E}-02$
$6.27 \mathrm{E}-02$

$6.27 \mathrm{E}-02$
$4.39 \mathrm{E}+02$

$0.00 \%$

$0.01 \%$
$99.24 \%$

$2.85 \mathrm{E}-01 \quad 0.06 \%$

$0.62 \%$

(a) Carbon Monoxide (CO)

$0.06 \%$

$1.86 \%$

$8.44 \%$

$15.21 \%$

(a) Non-methane Hydrocarbons (NMHCs) $5.12 \mathrm{E}-01$

(a) Hydrogen Sulfide (H2S)

$1.41 \mathrm{E}-08$

(a) Formaldehyde $(\mathrm{CH} 2 \mathrm{O})$

$1.46 \mathrm{E}+00$

$0.00 \%$

$0.33 \%$

$0.00 \%$

$0.13 \%$

7.14E-04 $0.00 \%$

(a) Nitrous Oxide (N2O)

(a) Particulates (unspecified)

(a) Sulfur Oxides (SOx as SO2)

$1.32 \mathrm{E}-01$

3.22E-01

$0.03 \%$
$0.07 \%$

$0.00 \%$

$43.31 \%$

$0.25 \%$

$16.80 \%$

$0.02 \%$

$3.93 \%$

$9.54 \%$

$0.19 \%$
$0.00 \%$
$0.46 \%$
$1.60 \%$
$2.84 \%$
$100.00 \%$
$0.02 \%$
$0.00 \%$
$1.65 \%$
$19.49 \%$
$38.05 \%$
$15.55 \%$

$0.00 \%$
$99.90 \%$
$14.89 \%$
$88.48 \%$
$94.90 \%$
$0.00 \%$
$96.89 \%$
$0.00 \%$
$81.40 \%$
$80.05 \%$
$15.45 \%$
$83.70 \%$

$1.60 \%$

$0.10 \%$

$0.10 \%$

$0.55 \%$

$0.28 \%$

$0.00 \%$

$0.05 \%$

$0.00 \%$

$0.14 \%$

$0.45 \%$

$0.04 \%$

$0.16 \%$

eneration

case (total)

\section{ng_loss_high}

(a) Ammonia (NH3)

(a) Benzene (C6H6)

(a) Carbon Dioxide (CO2)

2.10E-02

$6.50 \mathrm{E}-02$

$4.42 \mathrm{E}+02$

$204 \mathrm{E}-01$

$0.00 \%$

$0.01 \%$

$97.94 \%$

a) Carbon Monoxide (CO)

9.76E-01

(a) Non-methane Hydrocarbons (NMHCs)

(a) Hydrogen Sulfide (H2S)

$1.41 \mathrm{E}-08$

(a) Methane (CH4)

$6.90 \mathrm{E}+00$

$8.57 \mathrm{E}-03$

$5.83 \mathrm{E}-01$

7.34E-04

(a) Nitrogen Oxides (NOx as $\mathrm{NO} 2$ )

(a) Nitrous Oxide (N2O)

(a) Particulates (unspecified)

(a) Sulfur Oxides (SOx as SO2)

$0.07 \%$

$0.22 \%$

$1.53 \%$

$0.00 \%$

$0.13 \%$

$0.00 \%$

$0.03 \%$

$0.07 \%$

$0.23 \%$

$0.70 \%$

$3.15 \%$

$10.48 \%$

$0.00 \%$

$74.09 \%$

$0.09 \%$

$6.26 \%$

$0.01 \%$

$1.43 \%$

$3.56 \%$

$0.19 \%$
$0.00 \%$
$0.45 \%$
$1.55 \%$
$1.49 \%$
$100.00 \%$
$0.01 \%$
$0.00 \%$
$1.60 \%$
$18.94 \%$
$37.84 \%$
$15.09 \%$

$0.00 \%$

$99.90 \%$

$15.37 \%$

$88.84 \%$

$97.32 \%$

$0.00 \%$

$99.34 \%$

$0.00 \%$

$81.94 \%$

$80.61 \%$

$15.93 \%$

$84.18 \%$

$1.60 \%$

$0.10 \%$
$0.10 \%$

$0.10 \%$

$0.54 \%$

$0.15 \%$

$0.00 \%$

$0.01 \%$

$0.00 \%$

$0.14 \%$

$0.44 \%$

$0.04 \%$

$0.16 \%$

$98.21 \%$

$0.00 \%$

$84.55 \%$

$9.37 \%$

$1.98 \%$

$0.00 \%$

$3.04 \%$

$100.00 \%$

$16.81 \%$

$0.00 \%$

$46.46 \%$

$0.59 \%$

$-0.90 \%$

$-0.80 \%$

$-18.46 \%$

$-48.27 \%$

$-0.74 \%$

$-0.73 \%$

$-0.14 \%$

$-0.76 \%$

$0.00 \%$

$0.00 \%$

$0.00 \%$

\section{pipeline_high}

(a) Ammonia (NH3)

(a) Benzene (C6H6)

(a) Carbon Dioxide (CO2)

$0.00 \%$

$0.01 \%$

$98.91 \%$

$0.06 \%$

$0.14 \%$

$0.00 \%$

(a) Non-methane Hydrocarbons (NMHCs)

$2.87 \mathrm{E}-01$

a) Hydrogen Sulfide $(\mathrm{H} 2 \mathrm{~S})$

(a) Methane $(\mathrm{CH} 4)$

$1.62 \mathrm{E}-08$

$2.82 \mathrm{E}+00$

$0.63 \%$

$8.57 \mathrm{E}-03 \quad 0.00 \%$

(a) Formaldehyde $(\mathrm{CH} 2 \mathrm{O})$

(a) Nitrogen Oxides (NOx as NO2)

(a) Nitrous Oxide (N2O)

5.71E-01

7.41E-04

$0.13 \%$

$0.00 \%$

$0.03 \%$

(a) Sulfur Oxides (SOx as SO2)

$0.07 \%$

$0.43 \%$

$1.30 \%$

$5.90 \%$

$12.97 \%$

$0.00 \%$

$58.01 \%$

$0.18 \%$

$11.74 \%$

$0.02 \%$

$2.76 \%$

$6.69 \%$

$\begin{array}{rr}0.22 \% & 0.00 \% \\ 0.00 \% & 99.90 \% \\ 0.52 \% & 15.00 \% \\ 1.67 \% & 88.50 \% \\ 2.67 \% & 95.49 \% \\ 100.00 \% & 0.00 \% \\ 0.01 \% & 98.39 \% \\ 0.00 \% & 0.00 \% \\ 1.73 \% & 81.46 \% \\ 21.72 \% & 77.84 \% \\ 38.83 \% & 15.36 \% \\ 15.76 \% & 83.50 \%\end{array}$

$1.60 \%$

$0.10 \%$

$0.10 \%$

$0.55 \%$

$0.23 \%$

$0.00 \%$

$0.02 \%$

$0.00 \%$

$0.14 \%$

$0.44 \%$

$0.04 \%$

$0.16 \%$
$98.21 \%$

$0.00 \%$

$84.08 \%$

$9.07 \%$

$1.04 \%$

$0.00 \%$

$0.64 \%$

$100.00 \%$

$16.32 \%$

$0.00 \%$

$46.20 \%$

$0.57 \%$

$98.18 \%$

$0.00 \%$

$84.38 \%$

$9.28 \%$

$1.61 \%$

$0.00 \%$

$1.57 \%$

$100.00 \%$

$16.67 \%$

$0.00 \%$

$45.77 \%$

$0.59 \%$
$0.00 \%$

$2.71 \%$

$0.42 \%$

$2.40 \%$

$0.00 \%$

$144.52 \%$

$0.00 \%$

$2.21 \%$

$2.17 \%$

$2.27 \%$

$0.03 \%$

$0.00 \%$

$0.06 \%$

$0.08 \%$

$0.37 \%$

$14.94 \%$

$0.00 \%$

$0.00 \%$

$0.38 \%$ 
SENSITIVITY ANALYSIS RESULTS: AIR EMISSIONS (continued)

$\%$ of Total in Total $\%$ of Total this

$(\mathrm{g} / \mathrm{kWh})$ in this table CO2

$\%$ of Total from Construction \& $\%$ of Total from $\%$ Natural Gas $\%$ of Total from $\%$ of Total from Ammonia Electricity

$\%$ change pipeline_low

(a) Ammonia (NH3)

(a) Benzene (C6H6)

$2.10 \mathrm{E}-02$
$6.32 \mathrm{E}-02$

(a) Carbon Dioxide (CO2)

$4.39 \mathrm{E}+02$

2.87E-01

a) Carbon Monoxide (CO)

$\begin{array}{ll}\text { (a) Non-methane Hydrocarbons (NMHCs) } & 6.26 \mathrm{E}-01 \\ \text { (a) Hydrogen Sulfide (H2S) } & 1.20 \mathrm{E}-08\end{array}$

(a) Methane $(\mathrm{CH} 4)$

$1.20 \mathrm{E}-08$
$2.82 \mathrm{E}+00$

(a) Formaldehyde $(\mathrm{CH} 2 \mathrm{O})$

$2.82 \mathrm{E}+00$
$8.57 \mathrm{E}-03$

$5.70 \mathrm{E}-01$

6.97E-04

(a) Nitrous Oxide (N2O)

(a) Particulates (unspecified)

(a) Sulfur Oxides (SOx as SO2)

$1.31 \mathrm{E}-01$

3.23E-01

$0.00 \%$
$0.01 \%$
$98.91 \%$
$0.06 \%$
$0.14 \%$
$0.00 \%$
$0.63 \%$
$0.00 \%$
$0.13 \%$
$0.00 \%$
$0.03 \%$
$0.07 \%$

$0.43 \%$

$1.30 \%$

$5.91 \%$

$12.91 \%$

$0.00 \%$

$58.15 \%$

$0.18 \%$

$11.75 \%$

$0.01 \%$

$2.70 \%$

$6.65 \%$

$0.15 \%$
$0.00 \%$
$0.39 \%$
$1.51 \%$
$1.96 \%$
$100.00 \%$
$0.01 \%$
$0.00 \%$
$1.54 \%$
$16.84 \%$
$37.14 \%$
$15.11 \%$

$0.00 \%$
$99.90 \%$
$15.02 \%$
$88.64 \%$
$96.20 \%$
$0.00 \%$
$98.39 \%$
$0.00 \%$
$81.62 \%$
$82.70 \%$
$15.79 \%$
$84.14 \%$

Production

Generation

from base

case (total)

\section{NOx_Case1}

(a) Ammonia (NH3)

(a) Benzene (C6H6)

(a) Carbon Dioxide (CO2)

3.91E-05

6.32E-02

$4.38 \mathrm{E}+02$

$0.00 \%$

$0.01 \%$

$98.64 \%$

(a) Carbon Monoxide (CO)

$1.15 \mathrm{E}+00$

(a) Non-methane Hydrocarbons (NMHCs)

(a) Hydrogen Sulfide (H2S)

$6.27 \mathrm{E}-01$

(a) Methane $(\mathrm{CH} 4)$

$1.41 \mathrm{E}-08 \quad 0.00 \%$

(a) Formaldehyde $(\mathrm{CH} 2 \mathrm{O})$

$2.82 \mathrm{E}+00 \quad 0.64 \%$

(a) Nitrogen Oxides (NOx as NO2)

(a) Nitrous Oxide (N2O)

(a) Particulates (unspecified)

(a) Sulfur Oxides (SOx as SO2)

酯

$9.09 \mathrm{E}-01$

7.16E-04

1.33E-01

3.24E-01

$0.00 \%$

$0.20 \%$

$0.00 \%$

$0.03 \%$

$0.07 \%$

$$
0.00 \%
$$

$1.05 \%$

$19.04 \%$

$10.41 \%$

$0.00 \%$

$46.82 \%$

$0.00 \%$

$15.10 \%$

$0.01 \%$

$2.20 \%$

$5.37 \%$

$100.00 \%$
$0.00 \%$
$0.46 \%$
$0.40 \%$
$2.32 \%$
$100.00 \%$
$0.01 \%$
$0.00 \%$
$1.03 \%$
$19.44 \%$
$38.01 \%$
$15.46 \%$

$0.00 \%$

$100.00 \%$

$15.07 \%$

$22.15 \%$

$96.06 \%$

$0.00 \%$

$98.41 \%$

$0.00 \%$

$51.15 \%$

$80.56 \%$

$15.58 \%$

$83.95 \%$

$1.60 \%$
$0.10 \%$
$0.10 \%$
$0.55 \%$
$0.23 \%$
$0.00 \%$
$0.02 \%$
$0.00 \%$
$0.14 \%$
$0.47 \%$
$0.04 \%$
$0.16 \%$

$98.25 \%$

$0.00 \%$

$84.49 \%$

$9.30 \%$

$1.62 \%$

$0.00 \%$

$1.57 \%$

$100.00 \%$

$16.70 \%$

$0.00 \%$

$47.03 \%$

$0.59 \%$

$-0.03 \%$

$0.00 \%$

$-0.06 \%$

$-0.08 \%$

$-14.94 \%$

$-14.94 \%$

$0.00 \%$

$-0.09 \%$

$-3.03 \%$

$-1.36 \%$

$-0.38 \%$

\section{NOx_Case2}

(a) Ammonia (NH3)

(a) Benzene ( $\mathrm{C} 6 \mathrm{H} 6)$

(a) Carbon Dioxide (CO2)

2.11E-02

$0.00 \%$

$6.33 \mathrm{E}-02 \quad 0.01 \%$

$4.40 \mathrm{E}+02 \quad 98.92 \%$

(a) Carbon Monoxide (CO)

2.87E-01

$98.92 \%$
$0.06 \%$

$0.14 \%$

$0.00 \%$

(a) Hydrogen Sulfide (H2S)

(a) Methane $(\mathrm{CH} 4)$

$1.41 \mathrm{E}-08$

$2.82 \mathrm{E}+00$

$0.63 \%$

$8.57 \mathrm{E}-03 \quad 0.00 \%$

(a) Formaldehyde $(\mathrm{CH} 2 \mathrm{O})$

(a) Nitrogen Oxides (NOx as NO2)

(a) Nitrous Oxide (N2O)

7.19E-04

$0.11 \%$

$0.00 \%$

(a) Particulates (unspecified)

$1.33 \mathrm{E}-0$

$0.07 \%$

$0.44 \%$

$1.32 \%$

$6.00 \%$

$13.15 \%$

$0.00 \%$

$58.98 \%$

$0.18 \%$

$10.36 \%$

$0.02 \%$

$2.77 \%$

$6.78 \%$

$0.00 \%$

$0.00 \%$

$0.00 \%$

$0.00 \%$

$0.00 \%$

$0.00 \%$

$0.00 \%$

$0.00 \%$

$0.00 \%$

$0.00 \%$

$0.00 \%$

$0.00 \%$

$0.00 \%$

$0.00 \%$

$84.47 \%$

$77.45 \%$

$1.62 \%$

$0.00 \%$

$1.57 \%$

$0.00 \%$

$47.83 \%$

$0.00 \%$

$46.41 \%$

$0.59 \%$

$1.90 \%$

$0.12 \%$

$0.12 \%$

$0.65 \%$

$0.27 \%$

$0.00 \%$

$0.03 \%$

$0.00 \%$

$0.19 \%$

$0.54 \%$

$0.04 \%$

$0.19 \%$
$97.91 \%$

$0.00 \%$

$84.42 \%$

$9.28 \%$

$1.61 \%$

$0.00 \%$

$1.57 \%$

$100.00 \%$

$4.06 \%$

$0.00 \%$

$46.39 \%$

$0.59 \%$
$-99.81 \%$

$-0.10 \%$ $-0.40 \%$

$99.84 \%$

$-0.23 \%$

$-100.00 \%$

$59.43 \%$

$-0.45 \%$

$-0.04 \%$

$-0.16 \%$

$0.31 \%$

$0.02 \%$

$0.02 \%$

$0.11 \%$

$0.04 \%$

$0.00 \%$

$0.00 \%$

$0.00 \%$

$0.09 \%$

$0.01 \%$

$0.03 \%$ 
SENSITIVITY ANALYSIS RESULTS: AIR EMISSIONS (continued)

$\%$ of Total in Total $\%$ of Total this

$(\mathrm{g} / \mathrm{kWh})$ in this table $\mathrm{CO} 2$

\section{NOx Case 3}

\section{(a) Ammonia $(\mathrm{NH} 3)$}

(a) Benzene (C6H6)

(a) Carbon Dioxide (CO2)

(a) Carbon Monoxide (CO)

(a) Non-methane Hydrocarbons (NMHCs)

(a) Hydrogen Sulfide (H2S)

(a) Methane $(\mathrm{CH} 4)$

(a) Formaldehyde $(\mathrm{CH} 2 \mathrm{O})$

a) Nitrogen Oxides (NOx as $\mathrm{NO} 2$ )

(a) Nitrous Oxide (N2O)

(a) Particulates (unspecified)

(a) Sulfur Oxides (SOx as SO2)

\section{NOx Case4}

(a) Carbon Dioxide (CO2)

$3.91 \mathrm{E}-05$
$6.32 \mathrm{E}-02$

$4.38 \mathrm{E}+02$

$1.15 \mathrm{E}+00$

$6.27 \mathrm{E}-01$

$1.41 \mathrm{E}-08$

$2.82 \mathrm{E}+00$

$0.00 \mathrm{E}+00$

$1.11 \mathrm{E}+00$

7.16E-04

1.33E-01

3.24E-01

$0.00 \%$
$0.01 \%$
$98.60 \%$
$0.26 \%$
$0.14 \%$
$0.00 \%$
$0.63 \%$
$0.00 \%$
$0.25 \%$
$0.00 \%$
$0.03 \%$
$0.07 \%$

$\%$ of Total from

Construction \&

$\%$ of Total from $\%$ Natural Gas
Production Ammonia
Ammotal fr

$\%$ of Total from Electricity

$\%$ change Production

Production

Generation

case (total)

$$
\begin{array}{r}
100.00 \% \\
0.00 \% \\
0.46 \% \\
0.40 \% \\
2.32 \% \\
100.00 \% \\
0.01 \% \\
0.00 \% \\
0.84 \% \\
19.44 \% \\
38.01 \% \\
15.46 \%
\end{array}
$$

$0.00 \%$
$100.00 \%$
$15.07 \%$
$22.15 \%$
$96.06 \%$
$0.00 \%$
$98.41 \%$
$0.00 \%$
$41.95 \%$
$80.56 \%$
$15.58 \%$
$83.95 \%$

$0.00 \%$
$0.00 \%$
$0.00 \%$
$0.00 \%$
$0.00 \%$
$0.00 \%$
$0.00 \%$
$0.00 \%$
$0.00 \%$
$0.00 \%$
$0.00 \%$
$0.00 \%$

$$
0.00 \%
$$

$0.00 \%$

$84.47 \%$

$77.45 \%$

$1.62 \%$

$0.00 \%$
$1.57 \%$

$0.00 \%$

$57.21 \%$

$0.00 \%$

$46.41 \%$

$4.51 \%$
$0.59 \%$ (a) Methane $(\mathrm{CH} 4)$

$-99.81 \%$

$-0.10 \%$

$-0.40 \%$

$299.84 \%$

$-0.23 \%$

$0.00 \%$

$-0.02 \%$

$-100.00 \%$

$94.40 \%$

$-0.45 \%$

$-0.04 \%$

$-0.16 \%$ (a) Ammonia (NH3)

(a) Benzene $(\mathrm{C} 6 \mathrm{H} 6)$

(a) Carbon Monoxide (CO)

(a) Non-methane Hydrocarbons (NMHCs)

(a) Hydrogen Sulfide (H2S)

(a) Formaldehyde $(\mathrm{CH} 2 \mathrm{O})$

(a) Nitrogen Oxides (NOx as NO2)

(a) Nitrous Oxide (N2O)

(a) Particulates (unspecified)

(a) Sulfur Oxides ( $\mathrm{SOx}$ as $\mathrm{SO} 2$ )

$6.33 \mathrm{E}-02$

$4.40 \mathrm{E}+02$

2.88E-01

$6.29 \mathrm{E}-01$

$1.41 \mathrm{E}-08$

$2.82 \mathrm{E}+00$

$8.57 \mathrm{E}-03$

6.35E-01

7.21E-04

1.33E-01

3.24E-01

\section{$0.00 \%$}

$0.01 \%$

$98.89 \%$

$0.06 \%$

$0.14 \%$

$0.63 \%$

$0.00 \%$

$0.14 \%$

$0.00 \%$

$0.03 \%$

$0.07 \%$

\section{NOx_Case5}

(a) Ammonia (NH3)

(a) Benzene ( $\mathrm{C} 6 \mathrm{H} 6)$

(a) Carbon Dioxide (CO2)

2.18E-02

6.34E-02

$4.41 \mathrm{E}+02$

$2.91 \mathrm{E}-01$

(a) Carbon Monoxide (CO)

6.32E-01

(a) Hydrogen Sulfide (H2S)

(a) Methane $(\mathrm{CH} 4)$

$1.41 \mathrm{E}-08$

$2.82 \mathrm{E}+00$

(a) Formaldehyde $(\mathrm{CH} 2 \mathrm{O})$

(a) Nitrogen Oxides (NOx as NO2)

(a) Nitrous Oxide (N2O)

(a) Particulates (unspecified)

$8.57 \mathrm{E}-03$

8.32E-01

7.27E-04

1.33E-01

3.25E-01

$0.43 \%$
$1.28 \%$

$5.84 \%$

$12.78 \%$

$0.00 \%$

$57.29 \%$

$0.17 \%$

$12.90 \%$

$0.01 \%$
$2.69 \%$

$6.59 \%$

$$
\begin{array}{r}
0.18 \% \\
0.00 \% \\
0.46 \% \\
1.58 \% \\
2.31 \% \\
100.00 \% \\
0.01 \% \\
0.00 \% \\
1.47 \% \\
19.30 \% \\
37.99 \% \\
15.42 \%
\end{array}
$$

$99.84 \%$

$15.00 \%$

$88.29 \%$

$95.72 \%$

$0.00 \%$

$98.38 \%$

$0.00 \%$

$73.22 \%$

$79.98 \%$

$15.57 \%$

$83.74 \%$

$2.52 \%$

$0.16 \%$

$0.16 \%$

$0.36 \%$

$0.00 \%$

$0.04 \%$

$0.00 \%$

$0.20 \%$

$0.72 \%$

$0.06 \%$

$0.25 \%$

$0.00 \%$

$84.39 \%$

$9.26 \%$

$1.61 \%$

$0.00 \%$

$1.57 \%$

$100.00 \%$

$25.11 \%$

$0.00 \%$

$46.38 \%$

$0.59 \%$

$0.94 \%$

$0.06 \%$

$0.06 \%$

$0.32 \%$

$0.13 \%$

$0.00 \%$

$0.01 \%$

$0.00 \%$

$11.37 \%$

$0.27 \%$

$0.02 \%$

$0.09 \%$

(a) Sulfur Oxides (SOx as SO2)

\section{$0.00 \%$}

$01 \%$

$0.85 \%$

$0.14 \%$

$0.00 \%$

$0.63 \%$

$0.00 \%$

$0.00 \%$

$0.03 \%$

$0.07 \%$

$0.42 \%$
$1.24 \%$
$5.66 \%$
$12.32 \%$
$0.00 \%$
$55.03 \%$
$0.17 \%$
$16.22 \%$
$0.01 \%$
$2.59 \%$
$6.34 \%$

$0.18 \%$

$0.00 \%$

$0.46 \%$

$1.57 \%$

$2.30 \%$

$99.99 \%$

$0.01 \%$

$0.00 \%$

$1.12 \%$

$19.15 \%$

$37.97 \%$

$15.38 \%$

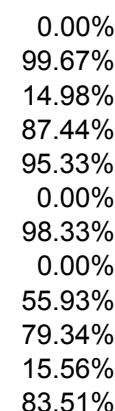

$5.20 \%$
$0.33 \%$
$0.33 \%$
$1.82 \%$
$0.76 \%$
$0.01 \%$
$0.08 \%$
$0.00 \%$
$0.32 \%$
$1.51 \%$
$0.12 \%$
$0.53 \%$

$94.62 \%$

$0.00 \%$

$84.24 \%$

$9.17 \%$

$1.61 \%$

$0.00 \%$

$1.57 \%$

$100.00 \%$

$100.00 \%$
$42.63 \%$

$0.00 \%$

$46.36 \%$

$0.59 \%$
$3.80 \%$

$0.23 \%$

$0.23 \%$

$0.54 \%$

$0.00 \%$

$0.06 \%$

$0.00 \%$

$45.80 \%$

$0.08 \%$

$0.37 \%$ 
SENSITIVITY ANALYSIS RESULTS: AIR EMISSIONS (continued)

\section{NOx Case6}

(a) Ammonia (NH3)

(a) Benzene $(\mathrm{C} 6 \mathrm{H} 6)$

(a) Carbon Dioxide (CO2)

(a) Carbon Monoxide (CO)

(a) Non-methane Hydrocarbons (NMHCs)

(a) Hydrogen Sulfide (H2S)

(a) Methane $(\mathrm{CH} 4)$

(a) Formaldehyde $(\mathrm{CH} 2 \mathrm{O})$

(a) Nitrogen Oxides (NOx as NO2)

(a) Nitrous Oxide (N2O)

(a) Particulates (unspecified)

(a) Sulfur Oxides (SOx as SO2)
$\%$ of Total in this table

Total \% of Total

$(\mathrm{g} / \mathrm{kWh})$ in this table

3.91E-05

6.32E-02

$4.38 \mathrm{E}+02$

$1.15 \mathrm{E}+00$

6.27E-01

$1.41 \mathrm{E}-08$

$2.82 \mathrm{E}+00$

$0.00 \mathrm{E}+00$

6.76E-01

7.16E-04

1.33E-01

3.24E-01

$0.01 \%$

$98.70 \%$

$0.26 \%$

$0.14 \%$

$0.00 \%$

$0.64 \%$

$0.00 \%$

$0.15 \%$

$0.00 \%$

$0.03 \%$

$0.07 \%$
$\%$ of Total from

Construction \&

except $\mathrm{CO} 2$

$0.00 \%$

$1.09 \%$

$$
\begin{array}{r}
19.81 \% \\
10.83 \% \\
0.00 \% \\
48.71 \% \\
0.00 \% \\
11.67 \% \\
0.01 \% \\
2.29 \%
\end{array}
$$

$\%$ of Total from Natural Gas

Production

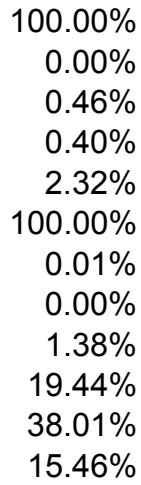

$0.00 \%$
$100.00 \%$
$15.07 \%$
$22.15 \%$
$96.06 \%$
$0.00 \%$
$98.41 \%$
$0.00 \%$
$68.82 \%$
$80.56 \%$
$15.58 \%$
$83.95 \%$

$15.46 \%$
$\%$ of Total from $\%$ of Total from

Ammonia

Production

$0.00 \%$
$0.00 \%$
$0.00 \%$
$0.00 \%$
$0.00 \%$
$0.00 \%$
$0.00 \%$
$0.00 \%$
$0.00 \%$
$0.00 \%$
$0.00 \%$
$0.00 \%$

Electricity

Generation

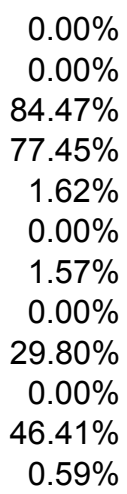

$\%$ change

from base

case (total)

$$
\begin{array}{r}
-99.81 \% \\
-0.10 \% \\
-0.40 \% \\
299.84 \% \\
-0.23 \% \\
0.00 \% \\
-0.02 \% \\
-100.00 \% \\
18.49 \% \\
-0.45 \% \\
-0.04 \% \\
-0.16 \%
\end{array}
$$




\section{SENSITIVITY ANALYSIS RESULTS: RESOURCES}

\section{Base case}

$\%$ of Total $\%$ of Total from in this

Total

Construction \&

$\%$ of Total from

$\%$ of Total from

Natural Gas

Ammonia

$\%$ of Total from $\%$ change

(g/kWh)

Decommisioning

Production

Production

Electricity

from base

(r) Coal (in ground)

(r) Iron (Fe, ore)

(r) Limestone (CaCO3, in ground)

(r) Natural Gas (in ground)

(r) Oil (in ground)

Iron Scrap

1.78
0.58

$1.02 \%$

$0.34 \%$

$0.36 \%$

$97.56 \%$

$0.36 \%$

$0.36 \%$

$33.79 \%$

$100.00 \%$

$100.00 \%$

$0.01 \%$

$32.18 \%$

$100.00 \%$

$65.47 \%$
$0.00 \%$
$0.00 \%$
$99.89 \%$
$67.66 \%$
$0.00 \%$

$0.75 \%$
$0.00 \%$
$0.00 \%$
$0.10 \%$
$0.16 \%$
$0.00 \%$

$\begin{array}{ll}0.00 \% & \text { N/A } \\ 0.00 \% & \text { N/A } \\ 0.00 \% & \text { N/A } \\ 0.00 \% & \text { N/A } \\ 0.00 \% & \text { N/A } \\ 0.00 \% & \text { N/A }\end{array}$

\section{cap_factor_75}

(r) Coal (in ground)

(r) Iron (Fe, ore)

(r) Limestone (CaCO3, in ground)

(r) Natural Gas (in ground)

(r) Oil (in ground)

Iron Scrap

$\begin{array}{rrr}181.58 \% & 1.05 \% & 35.24 \% \\ 0.62 & 0.36 \% & 100.00 \% \\ 0.66 & 0.38 \% & 100.00 \% \\ 169.25 & 97.47 \% & 0.01 \% \\ 0.63 & 0.36 \% & 33.60 \% \\ 0.67 & 0.39 \% & 100.00 \%\end{array}$

$64.03 \%$
$0.00 \%$
$0.00 \%$
$99.89 \%$
$66.24 \%$
$0.00 \%$

$0.73 \%$

$0.00 \%$

$0.00 \%$

$0.10 \%$

$0.16 \%$

$0.00 \%$

(r) Coal (in ground)

(r) Iron (Fe, ore)

(r) Limestone (CaCO3, in ground)

(r) Natural Gas (in ground)

(r) Oil (in ground)

Iron Scrap

$\begin{array}{rr}1.71 & 0.99 \% \\ 0.52 & 0.30 \% \\ 0.55 & 0.32 \% \\ 169.24 & 97.73 \% \\ 0.60 & 0.34 \%\end{array}$

$31.20 \%$
$100.00 \%$
$100.00 \%$
$0.01 \%$
$29.66 \%$

$0.56 \quad 0.32 \%$

$100.00 \%$

\section{cap_factor 95}

(r) Coal (in ground)

(r) Iron (Fe, ore)

(r) Limestone (CaCO3, in ground)

(r) Natural Gas (in ground)

(r) Oil (in ground)

Iron Scrap

$\begin{array}{rrr}1.68 & 0.97 \% & 30.05 \% \\ 0.49 & 0.28 \% & 100.00 \% \\ 0.52 & 0.30 \% & 100.00 \% \\ 169.24 & 97.80 \% & 0.01 \% \\ 0.59 & 0.34 \% & 28.55 \% \\ 0.53 & 0.31 \% & 100.00 \%\end{array}$

$68.02 \%$

\section{$0.00 \%$}

$0.00 \%$

$99.89 \%$

$70.17 \%$

$0.00 \%$

$0.78 \%$
$0.00 \%$
$0.00 \%$
$0.10 \%$
$0.17 \%$
$0.00 \%$

$0.00 \%$

$0.00 \%$

$0.00 \%$

$0.00 \%$

$0.00 \%$

$0.00 \%$

$-3.8 \%$

$-11.1 \%$

$-11.1 \%$

$0.0 \%$

$-3.6 \%$

$-11.1 \%$

$69.16 \%$
$0.00 \%$
$0.00 \%$
$99.89 \%$
$71.28 \%$
$0.00 \%$

$0.79 \%$
$0.00 \%$
$0.00 \%$
$0.10 \%$
$0.17 \%$
$0.00 \%$

$\begin{array}{rr}0.00 \% & -5.3 \% \\ 0.00 \% & -15.8 \% \\ 0.00 \% & -15.8 \% \\ 0.00 \% & 0.0 \% \\ 0.00 \% & -5.1 \% \\ 0.00 \% & -15.8 \%\end{array}$




\section{SENSITIVITY ANALYSIS RESULTS: RESOURCES (continued)}

\section{efficiency_high}

(r) Coal (in ground)

(r) Iron (Fe, ore)

(r) Limestone (CaCO3, in ground)

(r) Natural Gas (in ground)

(r) Oil (in ground)

Iron Scrap

$\%$ of Total $\%$ of Total from in this Construction \&

Total

table

Decommisioning

$\begin{array}{rr}1.61 & 1.02 \% \\ 0.53 & 0.34 \% \\ 0.56 & 0.36 \% \\ 153.51 & 97.56 \% \\ 0.56 & 0.36 \% \\ 0.57 & 0.36 \%\end{array}$

$$
\begin{array}{r}
33.79 \% \\
100.00 \% \\
100.00 \% \\
0.01 \% \\
32.18 \% \\
100.00 \%
\end{array}
$$

$\%$ of Total from Natural Gas

Production

$\%$ of Total from Ammonia

Production

change Electricity from base Generation case (total)

\section{efficiency_low}

(r) Coal (in ground)

(r) Iron (Fe, ore)

(r) Limestone (CaCO3, in ground)

(r) Natural Gas (in ground)

(r) Oil (in ground)

Iron Scrap

$\begin{array}{rrr}1.98 & 1.02 \% & 33.79 \% \\ 0.65 & 0.34 \% & 100.00 \% \\ 0.69 & 0.36 \% & 100.00 \% \\ 188.57 & 97.56 \% & 0.01 \% \\ 0.69 & 0.36 \% & 32.18 \% \\ 0.70 & 0.36 \% & 100.00 \%\end{array}$

(r) Coal (in ground)

(r) Iron (Fe, ore)

(r) Limestone (CaCO3, in ground)

(r) Natural Gas (in ground)

(r) Oil (in ground)

Iron Scrap

\section{ng_loss_high}

(r) Coal (in ground)

(r) Iron (Fe, ore)

(r) Limestone (CaCO3, in ground)

(r) Natural Gas (in ground)

(r) Oil (in ground)

Iron Scrap
$33.99 \%$

$\begin{array}{rrr}1.77 & 1.03 \% & 33.99 \% \\ 0.58 & 0.34 \% & 100.00 \% \\ 0.62 & 0.36 \% & 100.00 \% \\ 167.72 & 97.55 \% & 0.01 \% \\ 0.61 & 0.36 \% & 32.38 \%\end{array}$

$\begin{array}{lll}0.63 & 0.37 \% & 100.00 \%\end{array}$

$\begin{array}{rr}1.81 & 1.01 \% \\ 0.58 & 0.33 \% \\ 0.62 & 0.35 \% \\ 173.83 & 97.60 \% \\ 0.63 & 0.35 \% \\ 0.63 & 0.35 \%\end{array}$

$100.00 \%$
$33.20 \%$

$100.00 \%$

$100.00 \%$

$0.01 \%$

$31.60 \%$

$65.47 \%$
$0.00 \%$
$0.00 \%$
$99.89 \%$
$67.66 \%$
$0.00 \%$

$0.75 \%$
$0.00 \%$
$0.00 \%$
$0.10 \%$
$0.16 \%$
$0.00 \%$

$65.47 \%$
$0.00 \%$
$0.00 \%$
$99.89 \%$
$67.66 \%$
$0.00 \%$

$0.75 \%$

$0.00 \%$

$0.00 \%$

$0.10 \%$

$0.16 \%$

$0.00 \%$

$\begin{array}{ll}0.00 \% & -9.3 \% \\ 0.00 \% & -9.3 \% \\ 0.00 \% & -9.3 \% \\ 0.00 \% & -9.3 \% \\ 0.00 \% & -9.3 \% \\ 0.00 \% & -9.3 \%\end{array}$

$\begin{array}{ll}0.00 \% & 11.4 \% \\ 0.00 \% & 11.4 \% \\ 0.00 \% & 11.4 \% \\ 0.00 \% & 11.4 \% \\ 0.00 \% & 11.4 \% \\ 0.00 \% & 11.4 \%\end{array}$

$65.26 \%$

$0.00 \%$

$0.00 \%$

$99.89 \%$

$67.46 \%$

$0.00 \%$

$0.75 \%$
$0.00 \%$
$0.00 \%$
$0.10 \%$
$0.16 \%$
$0.00 \%$

$0.00 \%$

$0.00 \%$

$0.00 \%$

$0.00 \%$

$0.00 \%$

$0.00 \%$

$-0.6 \%$

$0.0 \%$

$0.0 \%$

$-0.9 \%$

$-0.6 \%$

$0.0 \%$

$\begin{array}{rr}66.07 \% & 0.73 \% \\ 0.00 \% & 0.00 \% \\ 0.00 \% & 0.00 \% \\ 99.89 \% & 0.10 \% \\ 68.24 \% & 0.16 \% \\ 0.00 \% & 0.00 \%\end{array}$

$\begin{array}{ll}0.00 \% & 1.8 \% \\ 0.00 \% & 0.0 \% \\ 0.00 \% & 0.0 \% \\ 0.00 \% & 2.7 \% \\ 0.00 \% & 1.8 \% \\ 0.00 \% & 0.0 \%\end{array}$




\section{SENSITIVITY ANALYSIS RESULTS: RESOURCES (continued)}

\section{pipeline_high}

(r) Coal (in ground)

(r) Iron (Fe, ore)

(r) Limestone (CaCO3, in ground)

(r) Natural Gas (in ground)

(r) Oil (in ground)

Iron Scrap

Total

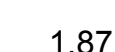

\section{pipeline_low}

(r) Coal (in ground)

(r) Iron (Fe, ore)

(r) Limestone (CaCO3, in ground)

(r) Natural Gas (in ground)

(r) Oil (in ground)

Iron Scrap

$\begin{array}{rr}1.68 & 0.97 \% \\ 0.47 & 0.27 \% \\ 0.61 & 0.35 \% \\ 169.24 & 97.76 \% \\ 0.61 & 0.35 \% \\ 0.51 & 0.30 \%\end{array}$

\section{NOx_Case1}

(r) Coal (in ground)

(r) Iron (Fe, ore)

(r) Limestone (CaCO3, in ground)

(r) Natural Gas (in ground)

(r) Oil (in ground)

Iron Scrap

\section{NOx Case2}

(r) Coal (in ground)

(r) Iron (Fe, ore)

(r) Limestone (CaCO3, in ground)

(r) Natural Gas (in ground)

(r) Oil (in ground)

Iron Scrap
$\%$ of Total $\%$ of Total from in this Construction \& table

Decommisioning

$\begin{array}{rr}1.87 & 1.08 \% \\ 0.69 & 0.40 \% \\ 0.63 & 0.36 \% \\ 169.25 & 97.37 \% \\ 0.63 & 0.36 \% \\ 0.75 & 0.43 \%\end{array}$

$$
\begin{array}{r}
37.27 \% \\
100.00 \% \\
100.00 \% \\
0.02 \% \\
33.13 \% \\
100.00 \%
\end{array}
$$

$$
\begin{array}{r}
29.89 \% \\
100.00 \% \\
100.00 \% \\
0.01 \% \\
31.20 \%
\end{array}
$$

$100.00 \%$

$\%$ of Total from Natural Gas

$\%$ of Total from Ammonia

Production

$66.71 \%$

$0.00 \%$

$34.04 \%$

$100.00 \%$

$100.00 \%$

$0.01 \%$

$32.23 \%$

$100.00 \%$

0.62

0.63

$0.36 \%$

$\begin{array}{rr}1.78 & 1.02 \% \\ 0.58 & 0.34 \% \\ 0.62 & 0.36 \% \\ 69.28 & 97.56 \% \\ 0.62 & 0.36 \% \\ 0.63 & 0.36 \%\end{array}$

$33.74 \%$

$100.00 \%$

$100.00 \%$

$0.01 \%$

$32.17 \%$

$100.00 \%$
$69.32 \%$

$0.00 \%$

$0.00 \%$

$99.89 \%$

$68.64 \%$

$0.00 \%$

$0.79 \%$

$0.00 \%$

$0.00 \%$

$0.10 \%$

$0.16 \%$

$0.00 \%$

$65.96 \%$

$0.00 \%$

$0.00 \%$

$99.99 \%$

$67.77 \%$

$0.00 \%$

$65.37 \%$

$0.00 \%$

$0.00 \%$

$99.87 \%$

$67.64 \%$

$0.00 \%$

$0.00 \%$

$0.00 \%$

$0.00 \%$

$0.00 \%$

$0.00 \%$

$0.00 \%$

$0.89 \%$

$0.00 \%$

$0.00 \%$

$0.12 \%$

$0.19 \%$

$0.00 \%$
$\%$ of Total from \% change

Electricity from base

Generation case (total)
$0.71 \%$

$0.00 \%$

$0.00 \%$

$0.10 \%$

$0.16 \%$

$0.00 \%$

$\begin{array}{rr}0.00 \% & 5.5 \% \\ 0.00 \% & 18.9 \% \\ 0.00 \% & 1.8 \% \\ 0.00 \% & 0.0 \% \\ 0.00 \% & 1.4 \% \\ 0.00 \% & 18.9 \%\end{array}$

$\begin{array}{rr}0.00 \% & -5.5 \% \\ 0.00 \% & -18.9 \% \\ 0.00 \% & -1.8 \% \\ 0.00 \% & 0.0 \% \\ 0.00 \% & -1.4 \% \\ 0.00 \% & -18.9 \%\end{array}$

$\begin{array}{lr}0.00 \% & -0.7 \% \\ 0.00 \% & 0.0 \% \\ 0.00 \% & 0.0 \% \\ 0.00 \% & -0.1 \% \\ 0.00 \% & -0.2 \% \\ 0.00 \% & 0.0 \%\end{array}$




\section{SENSITIVITY ANALYSIS RESULTS: RESOURCES (continued)}

\section{NOx_Case3}

(r) Coal (in ground)

(r) Iron (Fe, ore)

(r) Limestone ( $\mathrm{CaCO} 3$, in ground)

(r) Natural Gas (in ground)

(r) Oil (in ground)

Iron Scrap

\section{NOx_Case4}

(r) Coal (in ground)

(r) Iron (Fe, ore)

(r) Limestone (CaCO3, in ground)

(r) Natural Gas (in ground)

(r) Oil (in ground)

Iron Scrap

\section{NOx_Case 5}

(r) Coal (in ground)

(r) Iron (Fe, ore)

(r) Limestone (CaCO3, in ground)

(r) Natural Gas (in ground)

(r) Oil (in ground)

Iron Scrap

\section{NOx Case6}

(r) Coal (in ground)

(r) Iron (Fe, ore)

(r) Limestone (CaCO3, in ground)

(r) Natural Gas (in ground)

(r) Oil (in ground)

Iron Scrap
$\%$ of Total $\%$ of Total from in this Construction \&

Total

table

Decommisioning

$\begin{array}{rr}1.76 & 1.02 \% \\ 0.58 & 0.34 \% \\ 0.62 & 0.36 \% \\ 169.08 & 97.57 \% \\ 0.62 & 0.36 \% \\ 0.63 & 0.36 \%\end{array}$

$34.04 \%$

$100.00 \%$

$100.00 \%$

$0.01 \%$

$32.23 \%$

$100.00 \%$

$\%$ of Total from

Natural Gas

of Total from

Ammonia

Production

$65.96 \%$

$0.00 \%$

$0.00 \%$

$99.99 \%$

$67.77 \%$

$0.00 \%$

$33.64 \%$

$100.00 \%$

$100.00 \%$

$\begin{array}{rrr}69.34 & 97.56 \% & 0.01 \% \\ 0.62 & 0.36 \% & 32.15 \%\end{array}$

$\begin{array}{rrr}69.34 & 97.56 \% & 0.01 \% \\ 0.62 & 0.36 \% & 32.15 \%\end{array}$

$0.63 \quad 0.36 \%$

$100.00 \%$

$33.20 \%$

$100.00 \%$

$100.00 \%$

$0.01 \%$

$32.06 \%$

$69.64 \quad 97.55 \%$

$0.62-0.36 \%$

$0.36 \%$

$100.00 \%$

$65.18 \%$

$0.00 \%$

$0.00 \%$

$99.83 \%$

$67.59 \%$

$0.00 \%$

$64.33 \%$

$0.00 \%$

$0.00 \%$

$99.66 \%$

$67.40 \%$

$0.00 \%$

$34.04 \%$

$100.00 \%$

$100.00 \%$

$0.34 \%$

169.08

0.62

$97.57 \%$

$0.36 \%$

$0.36 \%$
$0.01 \%$

$32.23 \%$

$100.00 \%$
$65.96 \%$

$0.00 \%$

$0.00 \%$

$99.99 \%$

$67.77 \%$

$1.18 \%$

$0.00 \%$

$0.00 \%$

$0.16 \%$

$0.26 \%$

$0.00 \%$

$2.47 \%$

$0.00 \%$

$0.00 \%$
$0.00 \%$
$0.00 \%$
$0.00 \%$
$0.00 \%$
$0.00 \%$

$0.00 \%$
$0.00 \%$
$0.00 \%$
$0.00 \%$
$0.00 \%$
$0.00 \%$

tal from change

Electricity from base

Generation case (total)

$\begin{array}{lr}0.00 \% & -0.7 \% \\ 0.00 \% & 0.0 \% \\ 0.00 \% & 0.0 \% \\ 0.00 \% & -0.1 \% \\ 0.00 \% & -0.2 \% \\ 0.00 \% & 0.0 \%\end{array}$

$0.00 \%-0.0 \%$

$\begin{array}{ll}0.00 \% & 0.4 \% \\ 0.00 \% & 0.0 \% \\ 0.00 \% & 0.0 \% \\ 0.00 \% & 0.1 \% \\ 0.00 \% & 0.1 \% \\ 0.00 \% & 0.0 \%\end{array}$

$0.00 \% \quad 1.8 \%$

$0.00 \% \quad 0.0 \%$

$0.00 \% \quad 0.0 \%$

$0.00 \% \quad 0.2 \%$

$0.00 \% \quad 0.4 \%$

$0.00 \% \quad 0.0 \%$

$\begin{array}{lr}0.00 \% & -0.7 \% \\ 0.00 \% & 0.0 \% \\ 0.00 \% & 0.0 \% \\ 0.00 \% & -0.1 \% \\ 0.00 \% & -0.2 \% \\ 0.00 \% & 0.0 \%\end{array}$


SENSITIVITY ANALYSIS RESULTS: WASTE

\begin{tabular}{|c|c|c|c|c|c|c|}
\hline $\begin{array}{l}\text { Non-hazardous } \\
\text { miscellaneous } \\
\text { waste }\end{array}$ & Total (g/kWh) & $\begin{array}{l}\% \text { of Total from } \\
\text { Construction \& } \\
\text { Decommisioning }\end{array}$ & $\begin{array}{c}\% \text { of Total from } \\
\text { Natural Gas } \\
\text { Production }\end{array}$ & $\begin{array}{c}\% \text { of Total from } \\
\text { Ammonia } \\
\text { Production }\end{array}$ & $\begin{array}{c}\% \text { of Total from } \\
\text { Electricity } \\
\text { Generation }\end{array}$ & $\begin{array}{c}\% \text { diff from base } \\
\text { case (total) }\end{array}$ \\
\hline Base case & 6.52 & $6.2 \%$ & $93.6 \%$ & $0.2 \%$ & $0.0 \%$ & $0.0 \%$ \\
\hline cap_factor_75 & 6.55 & $6.6 \%$ & $93.3 \%$ & $0.2 \%$ & $0.0 \%$ & $0.4 \%$ \\
\hline cap_factor_90 & 6.48 & $5.5 \%$ & $94.3 \%$ & $0.2 \%$ & $0.0 \%$ & $-0.7 \%$ \\
\hline cap_factor_95 & 6.46 & $5.3 \%$ & $94.6 \%$ & $0.2 \%$ & $0.0 \%$ & $-1.0 \%$ \\
\hline efficiency_high & 5.91 & $6.2 \%$ & $93.6 \%$ & $0.2 \%$ & $0.0 \%$ & $-9.3 \%$ \\
\hline efficiency_low & 7.26 & $6.2 \%$ & $93.6 \%$ & $0.2 \%$ & $0.0 \%$ & $11.4 \%$ \\
\hline ng_loss_low & 6.47 & $6.2 \%$ & $93.6 \%$ & $0.2 \%$ & $0.0 \%$ & $-0.8 \%$ \\
\hline ng_loss_high & 6.69 & $6.0 \%$ & $93.8 \%$ & $0.2 \%$ & $0.0 \%$ & $2.5 \%$ \\
\hline pipeline_high & 6.58 & $7.1 \%$ & $92.7 \%$ & $0.2 \%$ & $0.0 \%$ & $1.0 \%$ \\
\hline pipeline_low & 6.46 & $5.2 \%$ & $94.6 \%$ & $0.2 \%$ & $0.0 \%$ & $-1.0 \%$ \\
\hline NOx_Case1 & 6.51 & $6.2 \%$ & $93.8 \%$ & $0.0 \%$ & $0.0 \%$ & $-0.2 \%$ \\
\hline NOx_Case2 & 6.52 & $6.2 \%$ & $93.6 \%$ & $0.2 \%$ & $0.0 \%$ & $0.0 \%$ \\
\hline NOx_Case3 & 6.51 & $6.2 \%$ & $93.8 \%$ & $0.0 \%$ & $0.0 \%$ & $-0.2 \%$ \\
\hline NOx_Case4 & 6.53 & $6.2 \%$ & $93.5 \%$ & $0.3 \%$ & $0.0 \%$ & $0.1 \%$ \\
\hline NOx_Case5 & 6.55 & $6.1 \%$ & $93.2 \%$ & $0.6 \%$ & $0.0 \%$ & $0.4 \%$ \\
\hline NOx_Case6 & 6.51 & $6.2 \%$ & $93.8 \%$ & $0.0 \%$ & $0.0 \%$ & $-0.2 \%$ \\
\hline
\end{tabular}




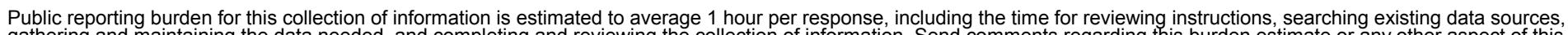

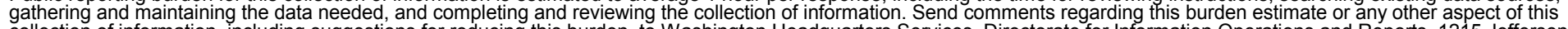

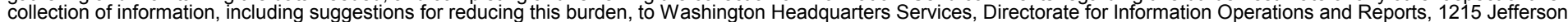
Davis Highway, Suite 1204, Arlington, VA 22202-4302, and to the Office of Management and Budget, Paperwork Reduction Project (0704-0188), Washington, DC 20503.

\begin{tabular}{|l|l|l|l|}
\hline 1. AGENCY USE ONLY (Leave blank) & $\begin{array}{c}\text { 2. REPORT DATE } \\
\text { September 2000 }\end{array}$ & $\begin{array}{l}\text { 3. REPORT TYPE AND DATES COVERED } \\
\text { Technical Report }\end{array}$ \\
\hline
\end{tabular}

4. TITLE AND SUBTITLE

Life Cycle Assessment of a Natural Gas Combined Cycle Power Generation System

6. $\operatorname{AUTHOR}(\mathrm{S})$

P.L. Spath and M.K. Mann

7. PERFORMING ORGANIZATION NAME(S) AND ADDRESS(ES)

National Renewable Energy Laboratory

1617 Cole Blvd.

Golden, CO 80401-3393

9. SPONSORING/MONITORING AGENCY NAME(S) AND ADDRESS(ES)
5. FUNDING NUMBERS

T: BP00.1030
8. PERFORMING ORGANIZATION REPORT NUMBER

NREL/TP-570-27715

10. SPONSORING/MONITORING AGENCY REPORT NUMBER

11. SUPPLEMENTARY NOTES

12a. DISTRIBUTION/AVAILABILITY STATEMENT

National Technical Information Service

U.S. Department of Commerce

5285 Port Royal Road

Springfield, VA 22161

13. ABSTRACT (Maximum 200 words)

Natural gas is used for steam and heat production in industrial processes, residential and commercial heating, and electric power generation. Because of its importance in the power mix, a life cycle assessment on electricity generation via a natural gas combined cycle system has been performed.

14. SUBJECT TERMS

life cycle assessment; natural gas; power plant

12b. DISTRIBUTION CODE

15. NUMBER OF PAGES

16. PRICE CODE

19. SECURITY CLASSIFICATION OF ABSTRACT Unclassified
20. LIMITATION OF ABSTRACT

UL 
